\title{
Exploring the Ring-Closing Metathesis for the \\ Construction of the Solomonamide Macrocylic Core: Identification of Bioactive Precursors
}

Iván Cheng-Sánchez, ${ }^{[\mathrm{a}]}$ Paloma Carrillo, ${ }^{[\mathrm{b}]}$ Antonio Sánchez-Ruiz, ${ }^{[\mathrm{c}]}$ Beatriz Martínez-Poveda, ${ }^{[b]}$ Ana R. Quesada, ${ }^{[b]}$ Miguel A. Medina, ${ }^{[b]}$

Juan M. López-Romero ${ }^{[a]}$ and Francisco Sarabia ${ }^{[\mathrm{a}] *}$

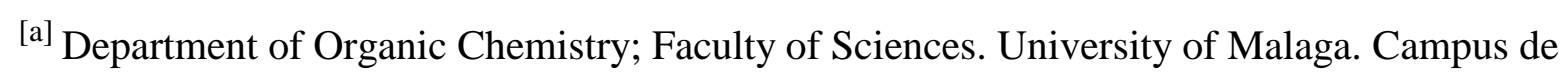
Teatinos s/n. 29071. Malaga (SPAIN)

${ }^{[b]}$ Department of Biochemistry and Molecular Biology; Faculty of Sciences. University of Malaga. Campus de Teatinos s/n. 29071. Malaga (SPAIN)

${ }^{[c]}$ Organic Chemistry Section; Faculty of Pharmacy. University of Castilla-La Mancha. Avda Dr. José María Sánchez Ibáñez s/n. 02008. Albacete (SPAIN)

Telephone: 34-952 134258. Fax: 34-952 131941

Email: $\underline{\text { rsarabia@uma.es }}$

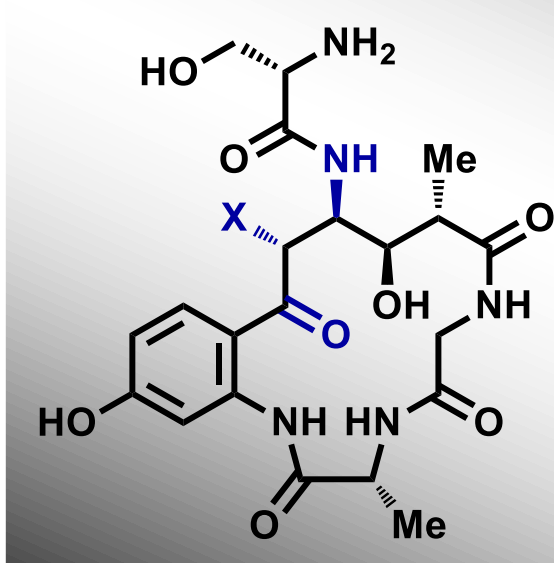

Solomonamide $\mathrm{A}: \mathrm{X}=\mathrm{OH}$ Solomonamide $\mathrm{B}: \mathrm{X}=\mathrm{H}$

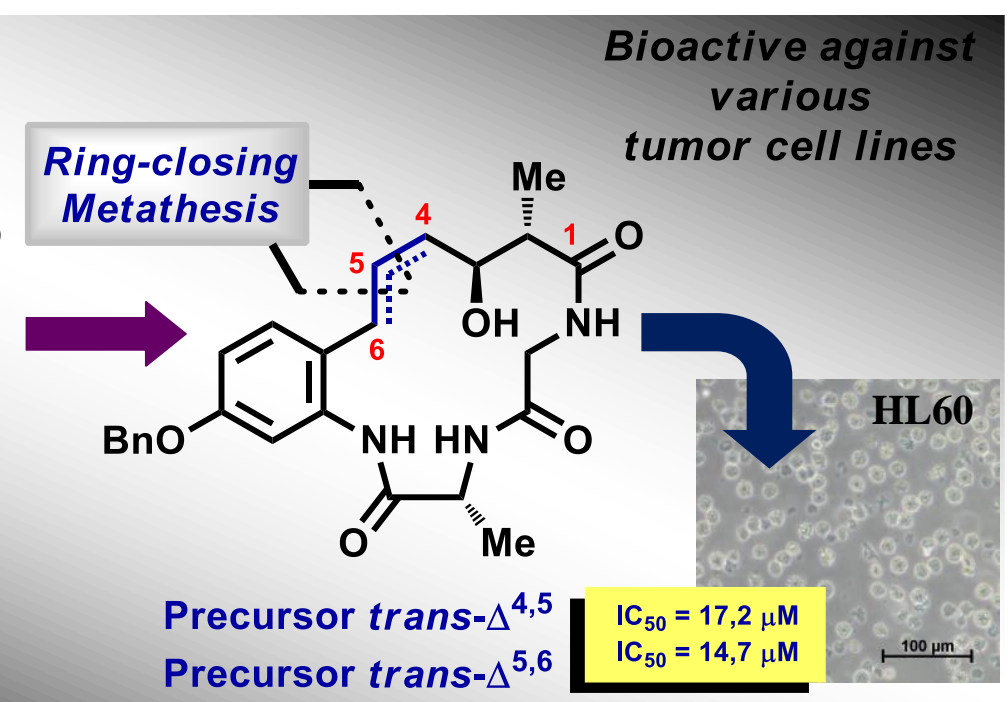

This is the preprint version of our manuscript, corresponding to the article that has been published in final form at JOURNAL OF ORGANIC CHEMISTERY with DOI: 10.1021/acs.joc.7b02988 


\begin{abstract}
New synthetic strategies directed towards the novel cyclopeptides solomonamides have been explored utilizing an olefin metathesis as the key reaction. In the various strategies investigated, we worked on minimally oxidized systems and the olefin metathesis reaction demonstrated efficiency and validity for the construction of the macrocyclic core. The described synthetic strategies towards the solomonamides are well suited for the subsequent access to the natural products and represent flexible and diversity-oriented routes that allow for the generation of a variety of analogues via oxidative transformations. In addition, preliminary biological evaluations of the generated solomonamide precursors revealed antitumor activity against various tumor cell lines.
\end{abstract}




\section{INTRODUCTION}

Recently isolated from the marine sponge Theonella swinhoei, the solomonamides A (1) and B (2) (Figure 1) are natural products with interesting and promising biological properties. ${ }^{1}$ Structurally characterized by unprecedented cyclopeptidic-type frameworks, these natural products have become potential leads for drug discovery and join a broad and impressive family of other bioactive natural products provided by this marine sponge. ${ }^{2}$ An exhaustive spectroscopic analysis of both compounds has resulted in the elucidation of their intricate cyclic structures, revealing the presence of three conventional amino acids (D-Ala, Gly and LSer) and an unprecedented 4-amino(2'-amino-4'-hydroxyphenyl)-3,5-dihydroxy-2-methyl-6oxohexanoic acid (ADMOA) and its corresponding 5-deoxy derivative (AHMOA) for solomonamides A and B, respectively. Assignment of the absolute configurations of ADMOA and AHMOA required additional studies, involving a combination of spectroscopic and theoretical studies (QM $J$ based analysis and DFT $J /{ }^{13} \mathrm{C}$ calculations), which resulted in the proposal of the depicted absolute configurations as the most likely. Biologically, solomonamide A (1) displayed potent anti-inflammatory activity, causing a significant $60 \%$ reduction of inflammation in an animal model of edema at $100 \mu \mathrm{g} / \mathrm{Kg}$. Unfortunately, the extreme scarcity of the solomonamides has precluded a thorough biological evaluation. In fact, the anti-inflammatory activity of solomonamide B (2) was not evaluated due to limited amounts. The unique and unprecedented structures of the solomonamides, together with their intriguing biological properties, have generated intense synthetic activity. ${ }^{3}$ For example, the Reddy group ${ }^{4}$ has recently reported a total synthesis of a deoxy analogue of solomonamide $\mathrm{B}^{5}$ together with an array of simple unfunctionalized analogues, ${ }^{6}$ culminating with a total synthesis of the natural solomonamide $\mathrm{B},{ }^{7}$ which has led to a revision of the initially proposed structure as will be detailed later. 
<smiles></smiles>

Solomonamide A (1)<smiles>CC(C)NC(=O)C(C)NC(=O)CNC(=O)[C@H](C)[C@H](O)[C@H](CC(=O)c1ccc(O)cc1NC(=O)[C@H](N)CO)NC(=O)[C@H](N)CO</smiles>

Solomonamide B (2)

Figure 1. Originally Assigned Structures of the Solomonamides

Our ongoing interest in the discovery and development of new potential leads based on cyclopeptidic- and cyclodepsipeptidaic-type compounds, ${ }^{8}$ prompted us to initiate a research program directed toward the total synthesis of this novel and unexplored class of cyclopeptides. With the aim of establishing a flexible and divergent synthetic strategy capable of providing not only the natural products, but also provide an entry into a plethora of analogues for biological studies, we sought to explore the ring-closing metathesis (RCM) reaction as the key step for construction of the macrocycle. ${ }^{9}$ This cyclisation step would be followed by an oxidation phase, which would incorporate the functional groups needed to reach the final oxidation stage found in the natural products. From a strategic perspective, we considered that the construction of the macrocyclic core at the 4,5-bond would be capable of providing rapid access not only to the final products, but also to analogues from late stage intermediates, allowing for the facile entry into numerous scaffolds. Furthermore, it is worthy to note that this synthetic strategy utilizes simple starting materials, avoiding the construction of the complex ADMOA residue, which can be constructed in the later stages of the synthesis through an epoxidation of the olefins 3-6, followed by an oxirane-ring opening process to introduce the amine group. Accordingly, as detailed in Scheme 1, our delineated strategy in retrosynthetic terms begins with the straightforward amide disconnection of the L-serine 
residue, followed by the removal of the functional groups, which would be introduced by means of oxidative manipulations (oxidation phase) of the resulting metathesis products. In this way, the synthetic strategy would render the corresponding macrocyclic alkenes represented by the $c i s-\Delta^{4,5}$ derivatives 3-6, which would possess or not various functionalities at the benzylic position. All these macrocyclic compounds, in turn, could be obtained from the corresponding acyclic precursors 7-10 via a ring-closing metathesis process. Finally, the preparation of such precursors would be achieved by simple peptidic-like assembly between the amine derivatives of the corresponding Boc derivatives 11-12 and the olefinic acids $\mathbf{1 3}$ or 14 (Scheme 1, part A). Preliminary results in this synthetic direction have been recently published $^{10}$ and support the viability of this approach. In this manuscript we wish to report a full account of all the synthetic studies carried out in our laboratories which have been initiated upon the basis of the previous retrosynthetic scheme. In addition, during the execution of this synthetic work, Reddy et al published the total synthesis of solomonamide B, based on an elegant intramolecular Heck reaction, which provided the advanced solomonamide precursor 15. More importantly, the total synthesis of solomonamide B led to the revision of the initially proposed structure for $\mathbf{2}$, with the correction of the configurations at $\mathrm{C}-3$ and at $\mathrm{C}-4$ positions to the $(3 S, 4 S)$-isomer (compound 16) instead of the proposed ( $3 R$, 4R) for solomonamide B (2) (Scheme 1, part B). ${ }^{7}$ As the present synthetic studies were initiated prior to the Reddy publication, we targeted the initially proposed structures for the solomonamides. 

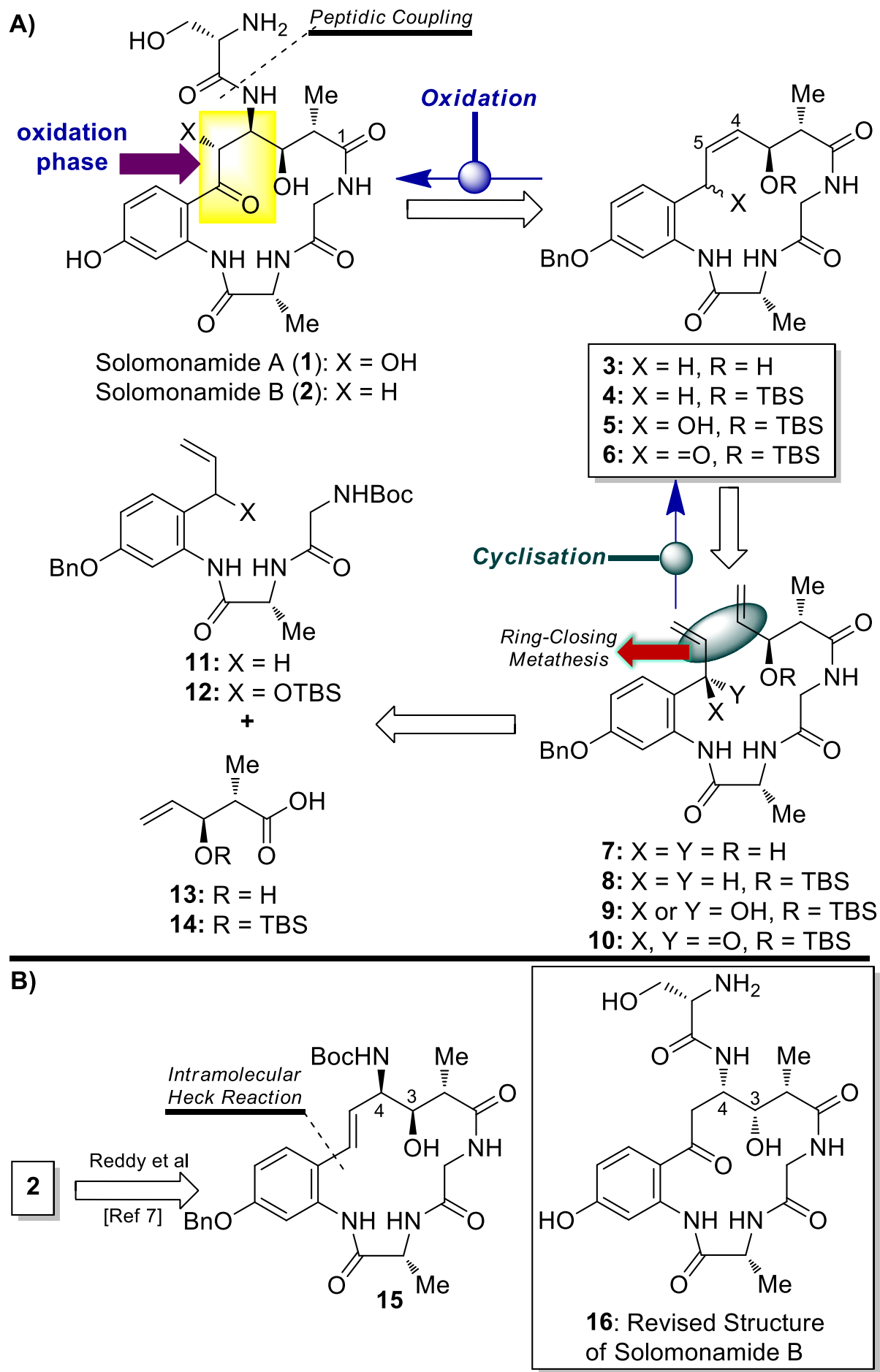

Scheme 1. Retrosynthetic Analysis for the Solomonamides (A) and Synthetic Work by Reddy (B) 


\section{RESULTS AND DISCUSSION}

2.1. Ring-Closing Metathesis at the C4-C5 Bond. Encouraged by the appealing features of this synthetic strategy, as mentioned above, we initiated the synthetic route. Our initial forays toward the solomonamide structures were conducted to demonstrate the viability of the olefin metathesis approach, based on the disconnection of the 4,5-positions bond, using the model compounds $\mathbf{2 4}$ and 25 (Scheme 2). To this end, the readily accessible dipeptides $\mathbf{2 4}$ and $\mathbf{2 5}$ were prepared from 2-bromo aniline $\mathbf{1 7}$ and the iodonitrobenzene derivative $\mathbf{1 8},{ }^{11}$ respectively, according to the synthetic sequence depicted in Scheme 2, entailing a Stille reaction for compound 19, and a sequential Stille reaction/reduction, for compound $\mathbf{2 0}$. Couplings of the resulting anilines $\mathbf{1 9}$ and $\mathbf{2 0}$ with dipeptide $\mathbf{2 1}{ }^{12}$ furnished the corresponding dipeptides 11 and 22, which, after Boc deprotection, were coupled with commercial acid 23 to yield the targeted ring-closing metathesis precursors $\mathbf{2 4}$ and $\mathbf{2 5}$. Thus, $\mathbf{2 4}$ and $\mathbf{2 5}$ were treated with $10 \mathrm{~mol} \%$ of Hoveyda-Grubbs $2^{\text {nd }}$ generation (HG-II) catalyst in refluxing dichloromethane in the presence of $p$-benzoquinone ${ }^{13}$ to obtain the expected macrocycles 26 and $\mathbf{2 7}$ in excellent 75 and $79 \%$ yields, respectively, as the sole products of the reaction. The newly formed double bonds $\left(\Delta^{4,5}\right)$ of $\mathbf{2 6}$ and $\mathbf{2 7}$ were determined in both cases to be exclusively in the $E$-configuration, as evidenced by a coupling constant $J$ of $15.9 \mathrm{~Hz}$, therefore revising our previous assignment, which was incorrect ${ }^{10}$ (Scheme 2).

Despite this stereochemical outcome, and with the possibility in mind that the structural pattern of the acyclic precursor could influence the double bond geometry and switch in favour to the desired $Z$-isomer, ${ }^{14}$ we continued with the assembly of compounds $\mathbf{1 1}$ and $\mathbf{1 4}^{10}$ in a manner similar to as described before for $\mathbf{2 4}$, providing $\mathbf{8}$ in a $74 \%$ overall yield. Upon exposure of $\mathbf{8}$ to HG-II catalyst, the expected macrocycle 4 was not obtained, instead recovering starting material, together with a significant degree of decomposition. Attributing 
steric factors to this failed cyclisation, the silyl protecting group was removed by treatment of $\mathbf{8}$ with HF•pyr to give allylic alcohol 7. Various reports in the literature, describing metathesis reactions involving allylic alcohols, indicate that these structural systems may favour the closing process, ${ }^{15}$ although other studies point out that these systems result in detrimental effects for the metathesis reaction. ${ }^{16}$ Nonetheless, when allylic alcohol 7 was subjected to the action of HG-II catalyst in dichloromethane at $40^{\circ} \mathrm{C}$ in the presence of $p$-benzoquinone, the $E$ olefin 28 was obtained exclusively in a gratifying $71 \%$ yield, with no formation of the required $Z$-isomer 3, as revealed by the ${ }^{1} \mathrm{H}$ NMR spectra of the crude reaction mixture (Scheme 3).

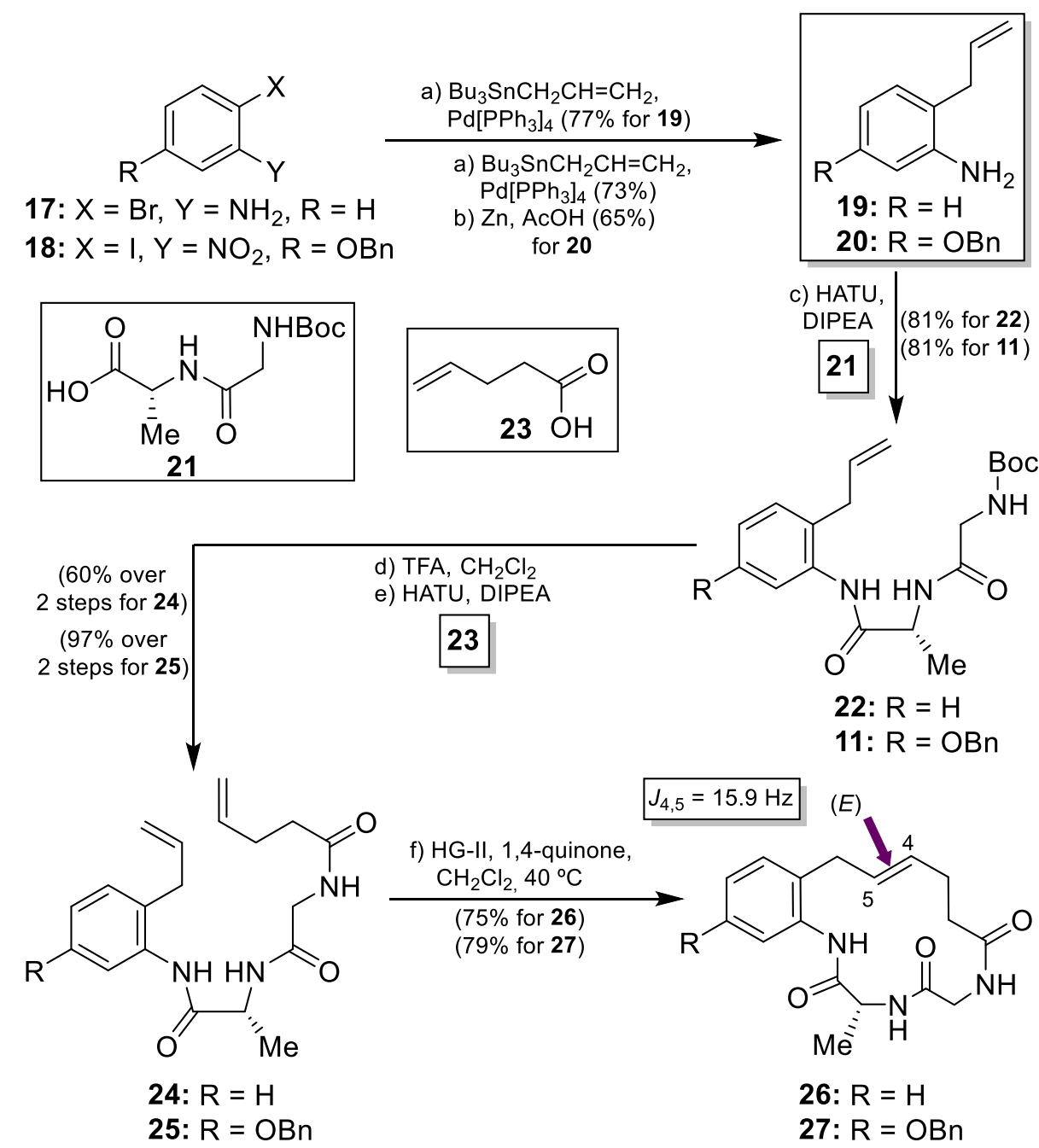

Scheme 2. Towards the Total Synthesis of Solomonamides: RCM of Model Compounds 24 and 25 


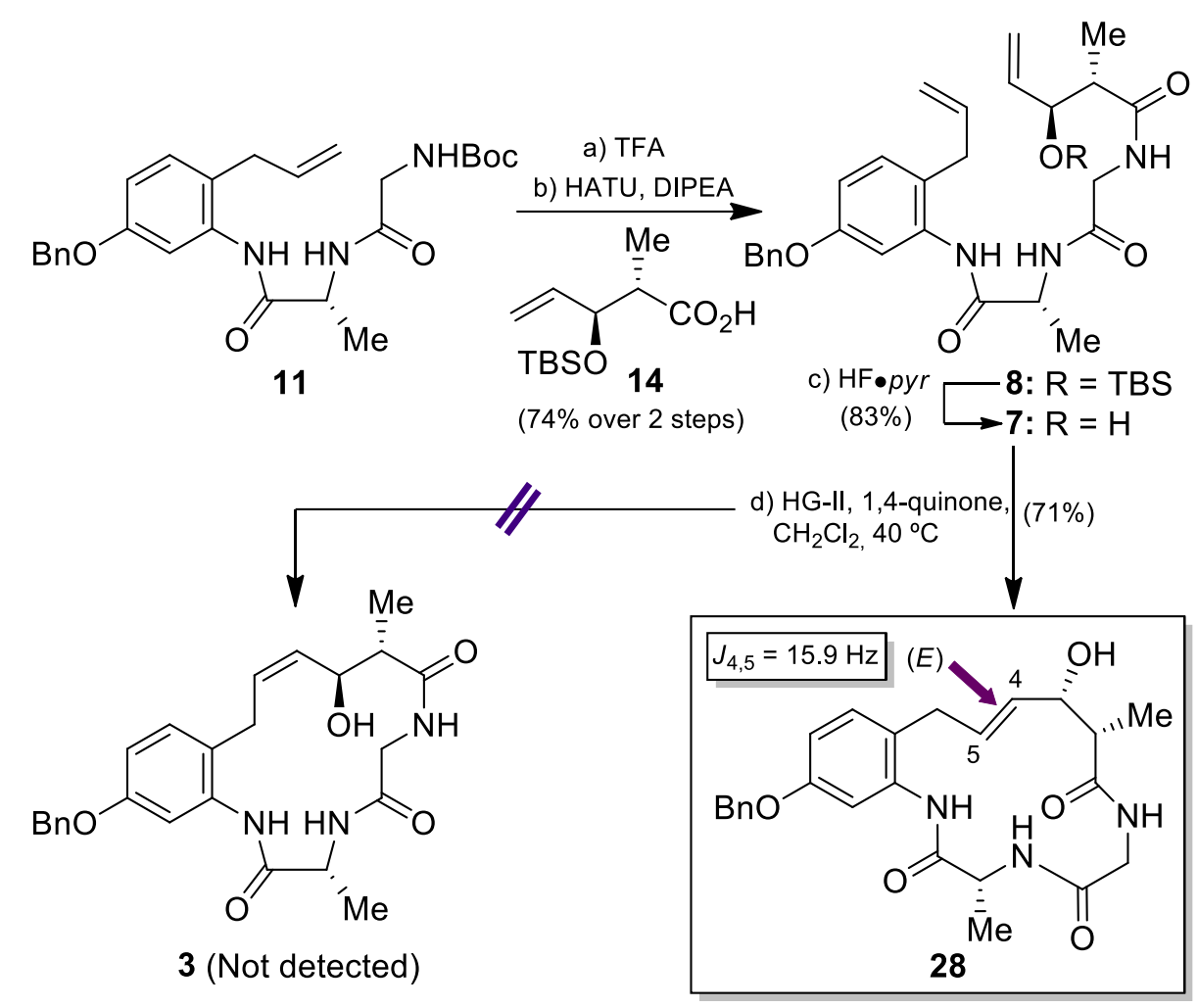

Scheme 3. Towards the Total Synthesis of Solomonamides: Synthesis of Macrocycle 28

In parallel to these preliminary works, we accomplished related synthetic studies extended to more functionalised precursors that would provide for a shortened the path towards the completion of the synthesis of these natural substances. In this direction, we pursued the preparation of the macrocycles 5 and $\mathbf{6}$ (See scheme 1) as potential advanced precursors. In order to rapidly inspect the validity of this approach, we initially worked with a model system represented by the deoxy aromatic derivatives. Thus, the readily accessible allylic alcohol $\mathbf{2 9}^{17}$ was transformed into the aniline $\mathbf{3 0}$ by treatment with $\mathrm{Zn} / \mathrm{NH}_{4} \mathrm{Cl}$. Following the delineated synthesis for previous compounds, $\mathbf{3 0}$ was coupled with dipeptide $\mathbf{2 1}$ to yield the coupled product $\mathbf{3 1}$ as a 1:1 mixture of diastereoisomers. The assembly of $\mathbf{3 1}$ with acid $\mathbf{2 3}$ was preceded by Boc deprotection under conventional acidic conditions, followed by amide coupling assisted by HATU. Disappointingly, the expected coupling product 32 was not detected, instead the derivative $\mathbf{3 3}$ was obtained as a result of a cationic rearrangement of the 
labile allylic alcohol 31, which probably occurred during the Boc deprotection step under the acidic conditions used (Scheme 4). Different attempts for removal the Boc group under mild acidic (TMSCl, TMSOTf, $\left.\mathrm{Sn}(\mathrm{OTf})_{2}, \mathrm{TiCl}_{4}, \mathrm{SnCl}_{4}\right)$, neutral $\left(\mathrm{I}_{2}, \mathrm{TBAF}, \mathrm{H}_{2} \mathrm{O}\right.$ at reflux) or basic conditions $\left(\mathrm{Na}_{2} \mathrm{CO}_{3}, \mathrm{~K}_{3} \mathrm{PO}_{4}, \mathrm{NaO}^{t} \mathrm{Bu}\right)^{18}$ resulted similarly unfruitful with the formation of rearranged byproducts, recovery of starting material or degradation, respectively. As a consequence of these results, we considered a direct coupling between aniline $\mathbf{3 0}$ and the peptidic fragment 36, which was efficiently prepared by utilising solid phase peptide synthesis (SPPS) as described in Scheme 4. Thus, the coupling of aniline $\mathbf{3 0}$ and acid $\mathbf{3 6}$ provided the desired diolefinic precursor $\mathbf{3 2}$ in a 77\% yield. Finally, the ring-closing metathesis of $\mathbf{3 2}$ under the same conditions as in previous cases, afforded the macrocyclic derivative $\mathbf{3 8}$ in a $73 \%$ yield as the $E$-isomer, supported by the $J_{4,5}$ coupling constant $(14.6 \mathrm{~Hz})$, and as a 1:1 mixture of diastereoisomers (Scheme 4). Interestingly, the protected precursor 37, prepared by silylation of $\mathbf{3 2}$ by the action of TBSOTf, did not provide the corresponding macrocylic derivative when it was subjected to the action of the HG-II catalyst under the same conditions used for 32, indicating that steric factors may be responsible for the failed ring closure.

The extension of this synthetic scheme to the aromatic system contained in the natural products was initiated with the aldehyde $\mathbf{4 0}$ prepared from commercially available $39 .{ }^{19}$ Subsequent treatment of aldehyde $\mathbf{4 0}$ with magnesium vinylbromide provided allylic alcohol 41, which required the reduction of the nitro group to the corresponding amine to give $\mathbf{4 2}$. This seemingly simple operation however proved more problematic than expected. For example, treatment of $\mathbf{4 1}$ with $\mathrm{Zn} / \mathrm{NH}_{4} \mathrm{Cl}$ did not provide the expected aniline $\mathbf{4 2}$, instead a complex mixture of unidentifiable degradation products were obtained. We surmised that the benzyloxy group installed in the aromatic ring was playing a crucial role in the reactivity of 
the benzylic alcohol, making it especially sensitive even under the weak acidic conditions of the reduction reaction.

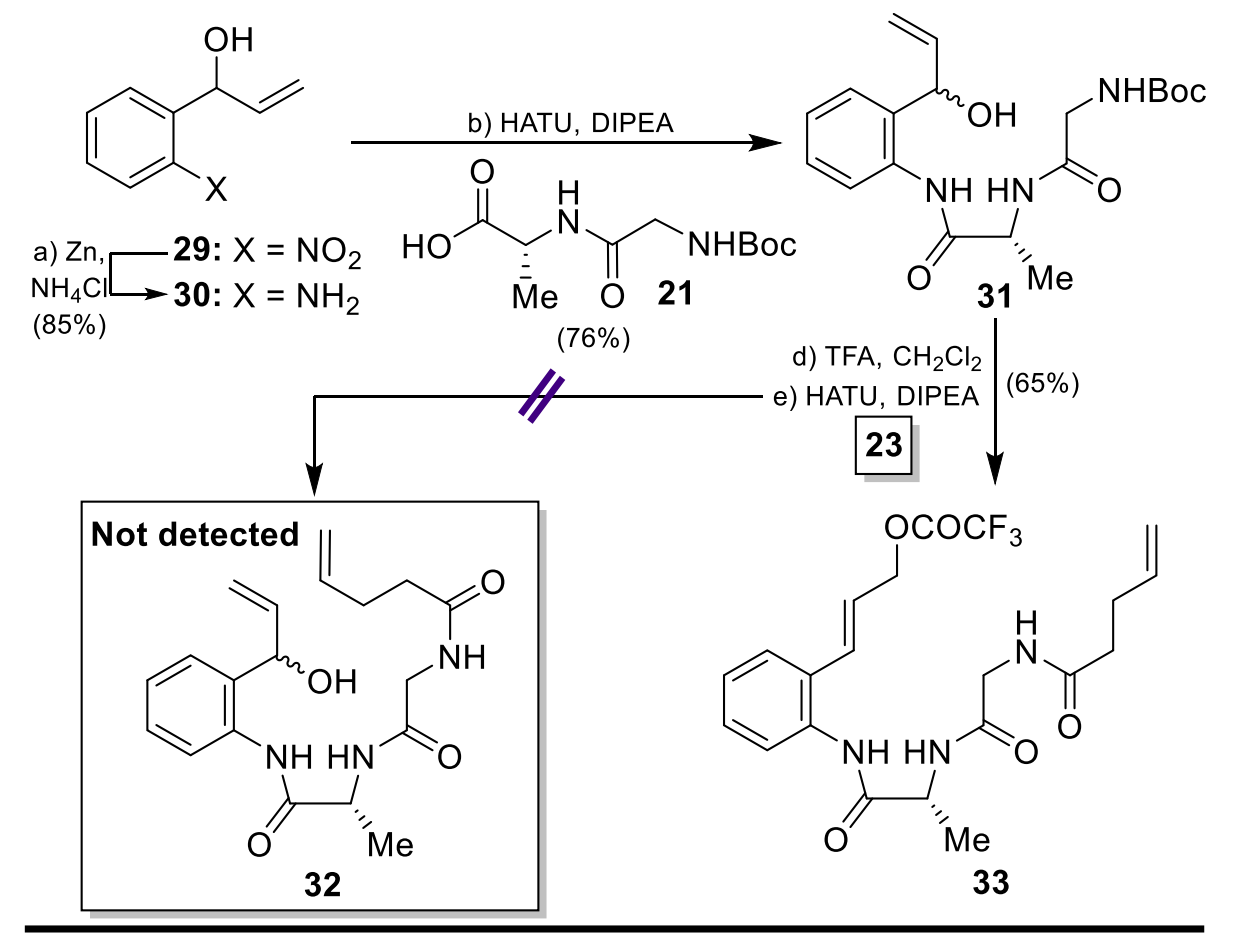

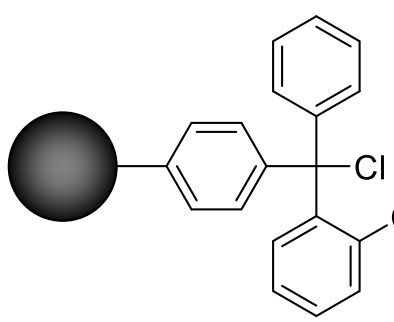

2-chlorotrityl chloride (CTC) polymer-bound

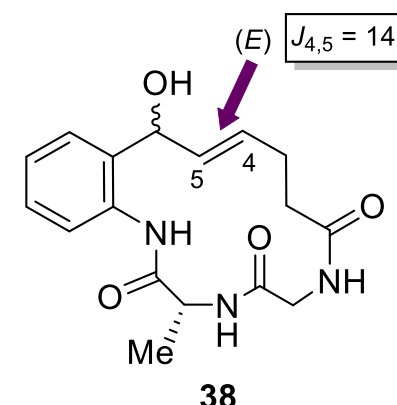

38

a) DIPEA, Fmoc-D-Ala (34)

b) Piperidine

c) DIC, $\mathrm{HOBt}$ Fmoc-Gly (35)
$\stackrel{\text { d) Piperidine }}{\longrightarrow}$

d) Piperidine 23

f) $\mathrm{AcOH} / \mathrm{CF}_{3} \mathrm{CH}_{2} \mathrm{OH}$

( $81 \%$ overall yield
from CTC resin)<smiles>C=CCCC(=O)NCC(=O)N[C@@H](C)C(=O)O</smiles>

g) HATU, DIPEA $(77 \%)$

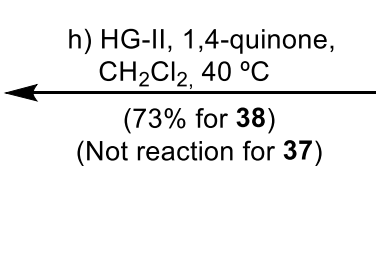

h) TBSOTf $32: \mathrm{R}=\mathrm{H}$

Scheme 4. Towards the Total Synthesis of the Solomonamides via Diolefin 32

To circumvent this rather disappointing outcome, we decided to protect the hydroxyl group as the silyl ether 43. However, the Zn-mediated reduction of the nitro group did not provide the 
expected aniline 44, instead the result again was the formation of a complex mixture of degradation products. Other reduction methods, including $\mathrm{LiAlH}_{4}$ or $\mathrm{Ni}$-Raney, were attempted but they also were unsucessful. Finally, the more robust $\mathrm{BOM}\left(\mathrm{PhCH}_{2} \mathrm{OCH}_{2}-\right)$ protecting group proved to be the solution for this problematic reduction, as the BOM derivative 45 provided the expected aniline 46 when treated with $\mathrm{Zn} / \mathrm{NH}_{4} \mathrm{Cl}$ in a reasonable and reproducible $79 \%$ yield. The linkage of aniline $\mathbf{4 6}$ and dipeptide $\mathbf{3 6}$ was then performed as described above for 32 to obtain compound 47, which was subjected to the ring-closing metathesis to provide macrocycle $\mathbf{4 8}$ in an excellent $84 \%$ yield as a $1: 1$ mixture of diastereoisomers and the E-olefin as the only detectable double bond isomer. It is intriguing that this ring-closing metathesis process proceeded in such good yield, despite the presence of a protecting group at the hydroxyl group of the diolefinic precursor (Scheme 5).

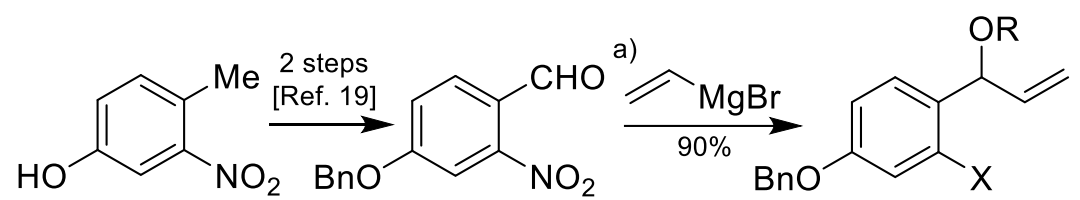
39<smiles>C=CCCC(=O)NCC(=O)NC(C)C(=O)O</smiles>

40 b) $\mathrm{Zn}$

41: $\mathrm{R}=\mathrm{H}, \mathrm{X}=\mathrm{NO}_{2}$

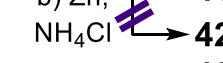

42: $\mathrm{R}=\mathrm{H}, \mathrm{X}=\mathrm{NH}_{2}$

43: $\mathrm{R}=\mathrm{TBS}, \mathrm{X}=\mathrm{NO}_{2}$

d) $\mathrm{Zn}$

$\mathrm{NH}_{4} \mathrm{Cl}$

44: $\mathrm{R}=\mathrm{TBS}, X=\mathrm{NH}_{2}$ e) $\mathrm{BOMC}$

f) $\mathrm{Zn}, \mathrm{NH}_{4} \mathrm{C}$

45: $\mathrm{R}=\mathrm{BOM}, \mathrm{X}=\mathrm{NO}_{2}$ $(88 \%)$

$(79 \%)$

46: $\mathrm{R}=\mathrm{BOM}, \mathrm{X}=\mathrm{NH}_{2}$

g) HATU, DIPEA

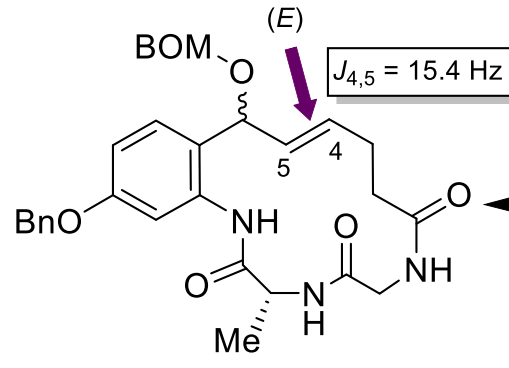

48

h) HG-II, 1,4-quinone,

$\mathrm{CH}_{2} \mathrm{Cl}_{2}, 40^{\circ} \mathrm{C}$ mixture of
stereoisomers) \begin{tabular}{|l|}
\hline 36 \\
\hline $75 \%)$
\end{tabular}

Scheme 5. Towards the Total Synthesis of the Solomonamides via Diolefin 47 
The implementation of this synthetic scheme onto the more functionalised system found in the natural products was then confronted by the assembly of acid 49, prepared by SPPS (See Experimental Part) and 46 under conventional conditions employed in this work (HATU/DIPEA). However, no desired product $\mathbf{5 0}$ was obtained despite attempts with an array of coupling reagents such as BOP, PyBOP, DIC/HOBt or DIC/HOAt. Reasoning that steric hindrances around the acid 49 could explain this failure, we attempted the synthesis of the advanced precursor 50 by sequential couplings of aniline 46 with the amino acid derivatives $\mathbf{3 4}$ and $\mathbf{3 5}$ and the less sterically encumbered acid 14. Unfortunately, the last coupling with acid 14 did not provide the expected product 50, instead a complex mixture of HATU derivatives was obtained from the starting acid. Intrigued by these failed reactions, we turned our attention to the simple aniline 30, in which the hydroxyl group at C6 position was free, in order to determine the reasons of the serious hurdles found during this synthetic course. To this end, aniline $\mathbf{3 0}$ and acid 49 were exposed to the action of HATU/DIPEA and the corresponding coupling product $\mathbf{5 1}$ was obtained, albeit in a low $36 \%$ yield, with the unexpected cleavage of the silyl protecting group. Several attempts of this reaction revealed its lack of reproducibility, confirming the difficulties of such a coupling. Although obtained in low yield, compound $\mathbf{5 1}$ was in hand and we were in position to investigate the ring-closing metathesis reaction for this more complex system. The reaction, undertaken under similar conditions as in previous cases, did not give the expected macrocycle 52, thus demonstrating the unsuitability of these substrates in the construction of the macrocylic core of the solomonamides via RCM. The reason for failure is most likely due to the sensitivity of the reaction to steric factors arising from the presence of substituents at both allylic and benzylic positions (scheme 6). 


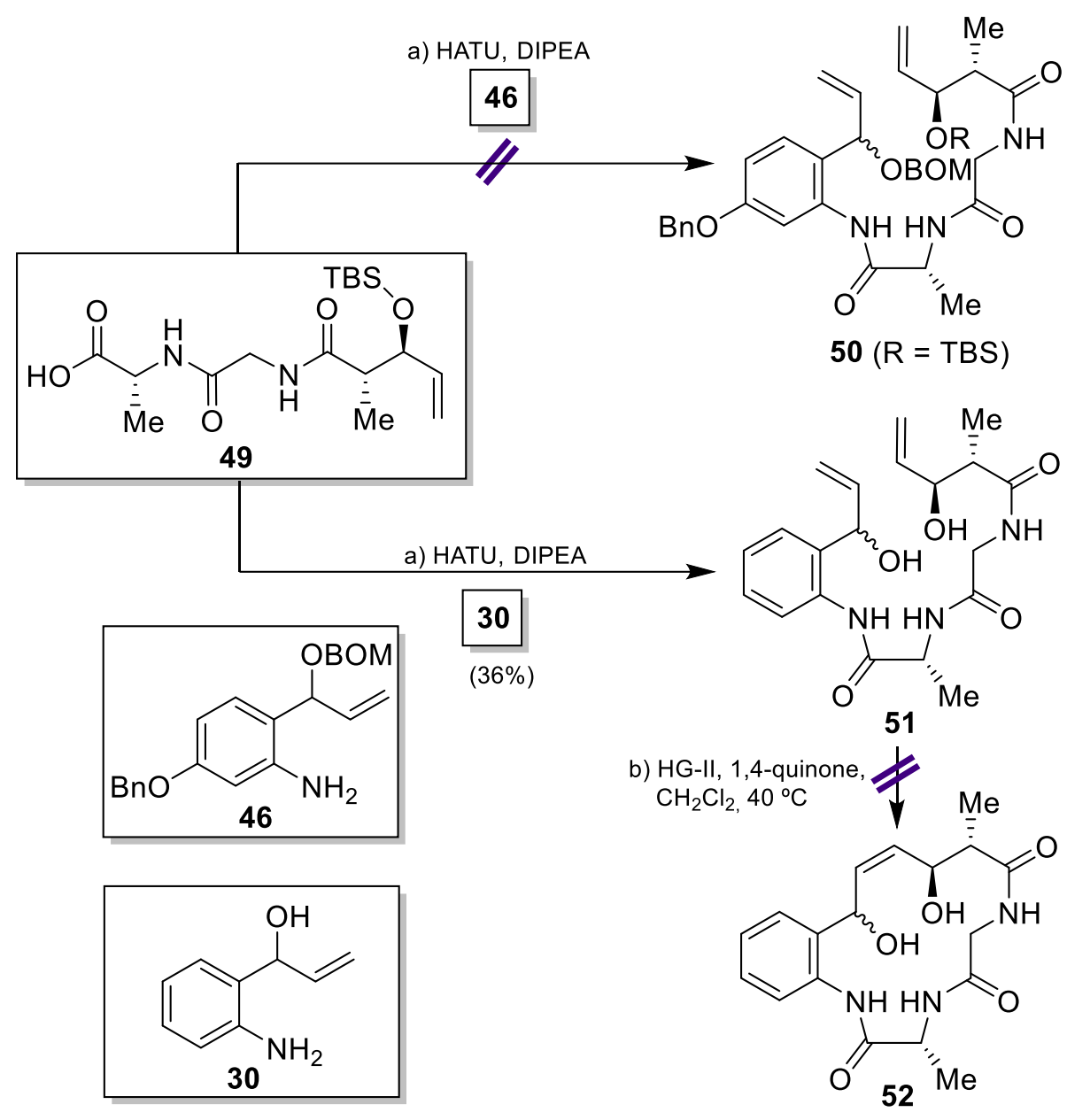

Scheme 6. Exploration of the RCM in More Complex Systems

In yet another attempt to access the macrocyclic solomonamide precursors functionalised at the benzylic position, we considered the incorporation of a ketone at this position, since this is the functional group present in the natural products. In addition, the generation of the $\alpha, \beta-$ unsaturated ketone system, after the macrocyclisation process, would allow for the rapid and facile access to an epoxide via oxidation of the double bond. Notably, we were skeptical about the success of the metathesis reaction in such a system, represented by compound $\mathbf{5 3}$, given that the olefin is unactivated as it is conjugated ( $\alpha, \beta$-unsaturated phenylketone). Despite this concern, we opted to experimentally verify the chemical reactivity of $\mathbf{5 3}$ under the action of the Hoveyda-Grubbs and related catalysts. 
To this aim, we prepared ketone $\mathbf{5 3}$ by oxidation of the alcohol 32 with $\mathrm{MnO}_{2}$ and then, subjected to the catalytic action of the Hoveyda-Grubbs $2^{\text {nd }}$ generation, keeping in mind the difficulty of this reaction due to the inactivated nature of the double bond of the $\alpha, \beta$ unsaturated ketone system. Indeed, this reaction did not provide any desired product, even when the reaction was forced using drastic conditions (ex. toluene at $60{ }^{\circ} \mathrm{C}$ and $100{ }^{\circ} \mathrm{C}$ ), instead providing recovered starting material in all cases. In another attempt to obtain cyclic ketone 54, cyclic alcohol 38 was treated with $\mathrm{MnO}_{2}$ but the result was similarly unsuccessful, with only starting material recovered and no detection of the coveted ketone $\mathbf{5 4}$ (Scheme 7).<smiles>C=CCCC(=O)NCC(=O)NC(C)C(=O)Nc1ccccc1[C@H](O)C=C</smiles>

Scheme 7. Exploration of the RCM of the Diolefinic ketone $\mathbf{5 3}$

Although a $Z$-geometry for the $\Delta^{4,5}$ double bond was proposed to provide access to the syn1,2-difunctionalized system present at these positions in the natural products, the fact that we obtained instead the $E$-olefinic macrocycles in all cases represented an additional difficulty in this study to obtain the final targets. Nonetheless, this synthetic strategy was not discarded at this point, as synthetic methods are available to provide the required syn isomer from a trans double bond. ${ }^{20}$ Consequently, we decided to continue with the present synthetic approach and 
the next step was to evaluate the feasibility of such compounds to provide more oxidized derivatives through an oxidation phase that would give access to the final products. In this sense, we studied the oxidation of compounds 27,28 and 48 as representative macrocyclic precursors of the solomonamides. Thus, when $\mathbf{2 7}$ or $\mathbf{2 8}$ were subjected to the oxidative action of $m$-CPBA, we found, to our dismay, that these reactions did not yield the expected epoxides 55 or 56. Instead, starting materials were recovered in both cases. In light of these discouraging results, we attempted the epoxidation utilizing the dioxirane derived from trifluoromethylketone,${ }^{21}$ however the result was similarly frustrating, with no formation of any desired oxidation products. Other oxidative reactions were screened, such as a dihydroxylation reaction mediated by $\mathrm{OsO}_{4}$, and electrophilic additions, mediated by the actions of bromine or NBS, but these did not provide favorable results, not detecting formation of any of the possible oxidation products. The poor solubility observed for these cyclic compounds in common organic solvents could explain the lack of reactivity found for them towards the oxidative reagents. However, the more soluble derivative $\mathbf{4 8}$ also proved to be unreactive when it was subjected to the epoxidation reagents ( $m$-CPBA and dioxirane species), resulting in the recovery of starting material and no detection of epoxide $\mathbf{5 7}$ (Scheme 8). Theoretical studies are currently in progress in order to justify the lack of reactivity exerted by these macrocyclic compounds. Thus, initial results from DFT calculations carried out in solution showed that the HOMO orbital of the molecules is centered around the intracyclic phenyl ring with a low electronic density around the alkene moiety. ${ }^{22}$ This result suggests that the main reactive point for the oxidant should not be the alkene, as it could be expected, but the aromatic ring. At this stage, no further work was required to recognize that oxidation of the previous solomonamide precursors was extremely hard to accomplish. Therefore, a new approach was considered. 


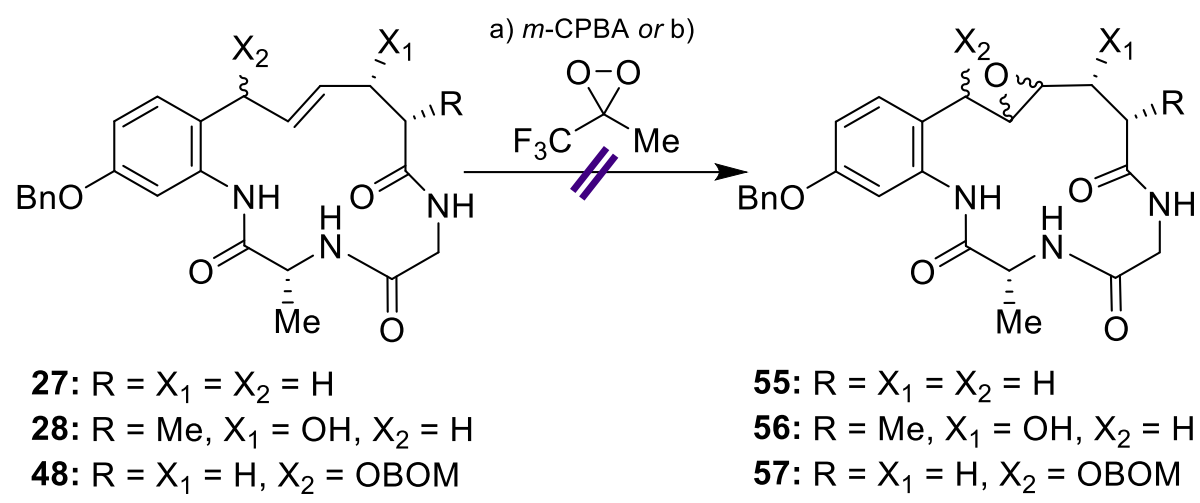

Scheme 8. Attempts of Oxidation of the RCM Products

2.2. Ring-Closing Metathesis at the C5-C6 Bond. Given the results obtained during the synthetic studies towards the solomonamides utilizing the macrocyclic construction at the C4C5 bond, we turned our attention to the construction of the macrocyclic core of the solomonamides at the C5-C6 bond. In relation to the synthetic strategy explored in the previous section, the removal of the functional groups, which should be accessible during an oxidation phase, would lead to the relatively simple precursor $\mathbf{5 8}$. Whereas the styryl double bond could be transformed into a ketone or an $\alpha$-hydroxy ketone via Wacker or dihydroxylation oxidations for solomonamides A and B, respectively, the introduction of the required amine group at the $\mathrm{C} 4$ position was initially planned via a $\mathrm{C}-\mathrm{H}$ activation. The syntheses of the key precursor $\mathbf{5 8}$ would be performed by a RCM of the acyclic derivative $\mathbf{5 9}$, whose synthesis would be achieved by simple peptidic-like assemblies between the corresponding amine and olefinic acid. As in the previous synthetic exploration, we preferred to initiate this study with the model compound $\mathbf{6 3}$ to test the viability of the new synthetic proposal. The preparation of this RCM precursor was successfully achieved from the simple aniline $\mathbf{6 0}^{23}$ by sequential couplings with dipeptide 21 and hydroxy acid $\mathbf{6 2}^{10,24}$ with HATU. With compound 63 in hand, we proceeded with the olefin metathesis reaction by use of the HG-II catalyst in refluxing dichloromethane. However, it was with much disappointment, that 
this reaction failed to afford any macrocyclic product, leading instead to decomposition and/or polymerization, together with the recovery of some starting material $(\sim 12 \%)$. Additional attempts that included more forcing conditions (toluene at $65^{\circ} \mathrm{C}$ or $100{ }^{\circ} \mathrm{C}$ ) and other catalysts (Grubbs $1^{\text {st }}$ and $2^{\text {nd }}$ generations, Hoveyda-Grubbs $1^{\text {st }}$ generation) were thwarted, with no detection of the desired macrocyclic product 64 (Scheme 9).
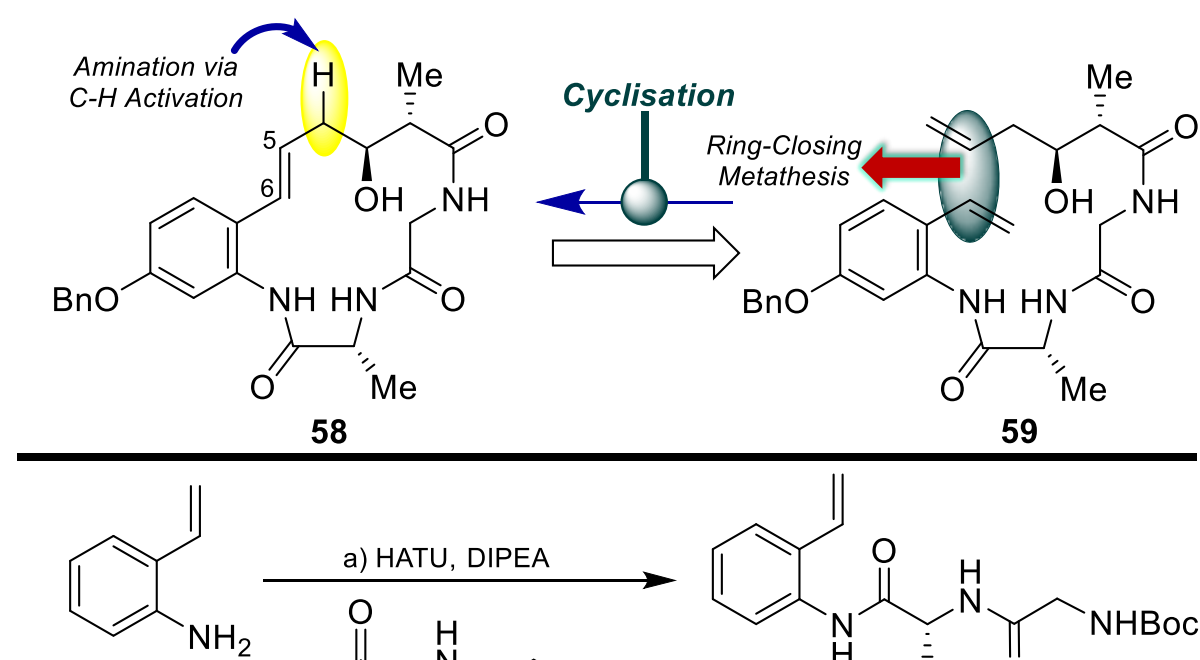

a) HATU, DIPEA<smiles>C=Cc1ccccc1NC(=O)[C@H]([14CH3])NC(=O)CNC(=O)O</smiles>

60

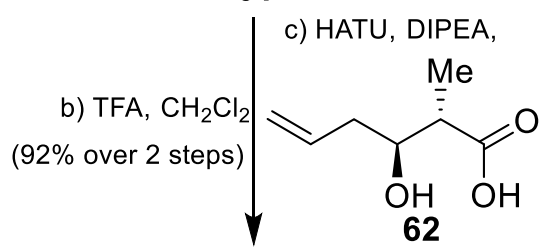<smiles></smiles><smiles>C=CC[C@@H](O)[C@@H](C)C(=O)NCC(=O)N[C@@H](C)C(=O)Nc1ccccc1C=C</smiles>

Scheme 9. Second Approach to the Solomonamides via RCM: The C5-C6 Disconnection

Despite these discouraging results, we decided to press forward with the synthetic strategy by exploring the ring closing metathesis in the real system represented by the product $\mathbf{5 9}$. We reasoned that in the case of the metathesis precursor 59, the electronic effect of the benzyloxy 
group at the para position with respect to the styryl double bond could exert a favourable effect in terms of reactivity for the unreactive olefin. In order to confirm this hypothesis, we prepared the styryl derivative $\mathbf{6 7}$ from compound $\mathbf{6 5}$ in a very good overall yield. We then proceeded to test the construction of the macrocyclic ring of the solomonamide model system 70. To this end, compound 67 was coupled with commercial acid 68 to obtain the acyclic precursor 69 in a $74 \%$ yield. Having prepared compound 69, we were primed to test our hypothesis regarding the favourable electronic donating effect of the benzyloxy group on the ring-closing metathesis reaction. Indeed, we were gratified to discover that cyclic compound 70 was obtained in a $43 \%$ yield and, exclusively, as the $E$-isomer, when the acyclic precursor 69 was subjected to the action of HG-II catalyst in refluxing dichloromethane in the presence of 1,4-benzoquinone (Scheme 10). In light of this encouraging result, the ring-closing metathesis was extended to the advanced intermediate 59, which was efficiently prepared from the Boc derivative 67 and acid 62 in $86 \%$ overall yield, according to the previously described fragment coupling protocol. To our dismay, treatment of $\mathbf{5 9}$ with the HG-II catalyst, under the same conditions previously employed in earlier cases, did not provide the coveted solomonamide precursor 58, providing instead degradation products and recovered starting material. A possible explanation for the failure of the metathesis reaction is the formation of either the five-membered ring intermediate $\mathbf{A},{ }^{25}$ by chelation of the ruthenium carbenoid with the hydroxyl group, or the seven-membered ring chelate intermediate $\mathbf{B},{ }^{26}$ in which sequestration of the ruthenium carbenoid species occurred through a hydrogen bond of the hydroxyl group with the chlorine atom, which could explain the inactivation of the catalyst for the RCM (Scheme 10). 


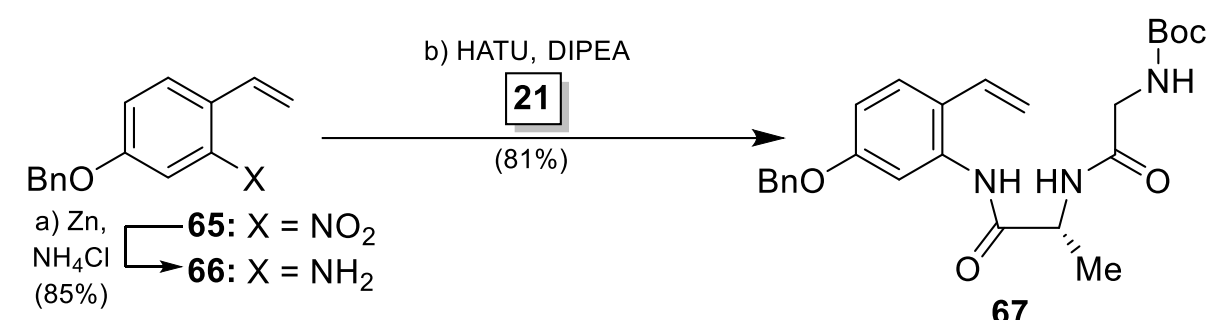

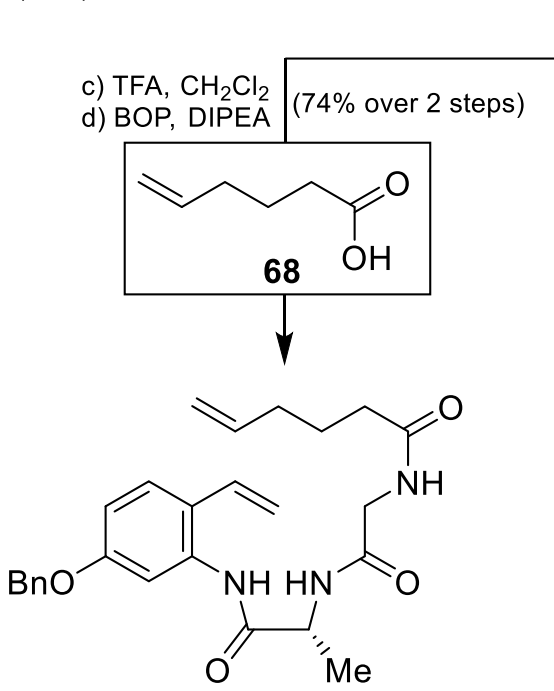

69
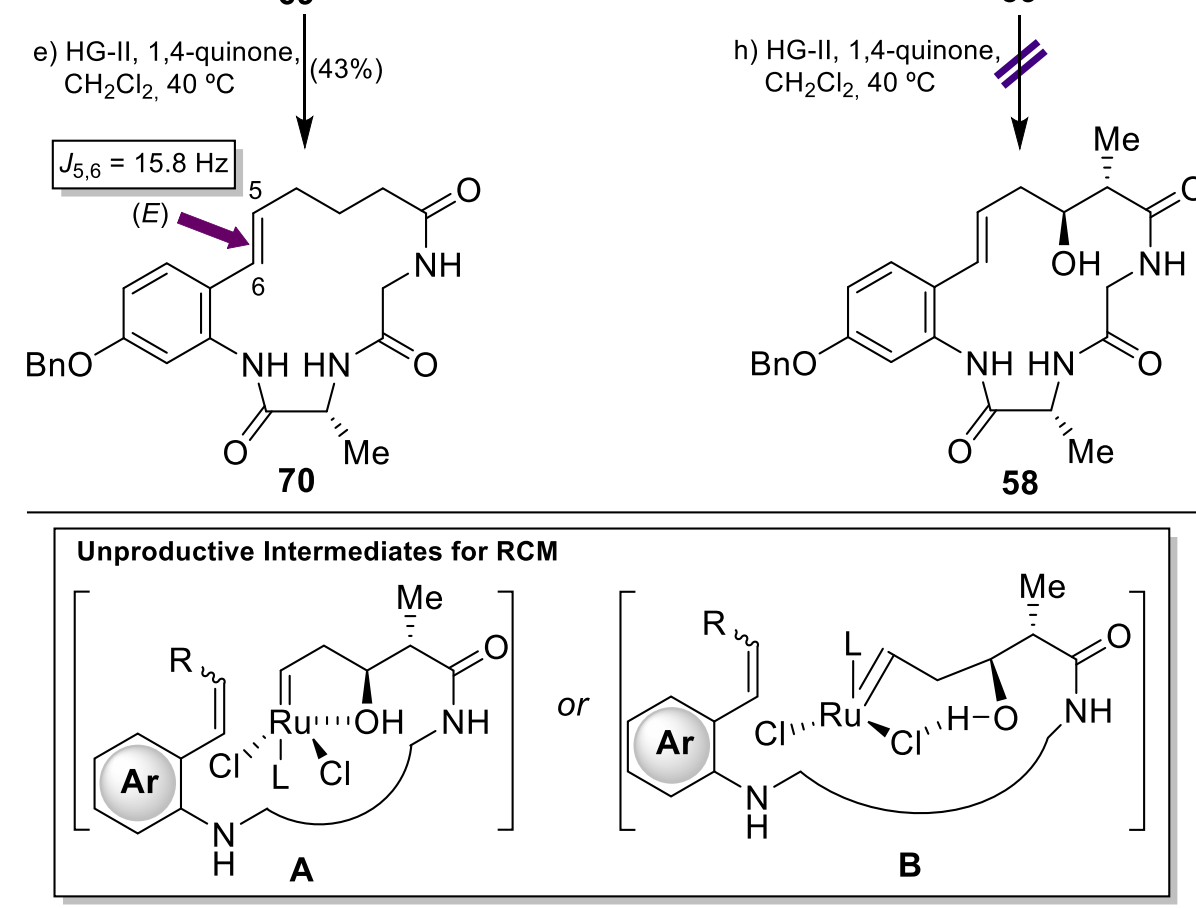

Scheme 10. RCM of the Acyclic Precursors 59 and 69

As support for this mechanistic hypothesis, ${ }^{27}$ we decided to protect the hydroxyl group to avoid the formation of the proposed unproductive intermediates. Therefore, the TBS 
derivative $\mathbf{7 1}$ was prepared in a good yield by treatment of $\mathbf{5 9}$ with TBSOTf in the presence of 2,6-lutidine. The resulting silyl ether $\mathbf{7 1}$ was then subjected to the action of the HG-II catalyst and, to our delight, the macrocyclic product $\mathbf{7 2}$ was obtained in a reasonable $47 \%$ yield. The completion of the synthesis of the natural products should require an eventual removal of the TBS protecting group. With this future objective in mind, we proceeded with the desilylation reaction by treatment of $\mathbf{7 2}$ with $\mathrm{HF} \bullet p y r$. Surprisingly, the expected hydroxyl derivative $\mathbf{5 8}$ was not obtained, instead recovered starting material. Other fluoride-based reagents (TBAF, TBAF-AcOH) afforded the same frustrating result. Therefore, we decided to replace the TBS group with a more labile protecting group, choosing TES as a suitable alternative. Then, compound $\mathbf{7 3}$ was prepared by reaction of $\mathbf{5 9}$ with TESOTf/2,6-lutidine and its suitability as a viable substrate for the preparation of $\mathbf{5 8}$ was evaluated. Gratifyingly, the RCM reaction of $\mathbf{7 3}$ provided 74 in a similar yield as for $72(53 \%)$ and its desilylation, by treatment with TBAF, yielded the desired macrocyclic $\mathbf{5 8}$ in $85 \%$ yield (Scheme 11).

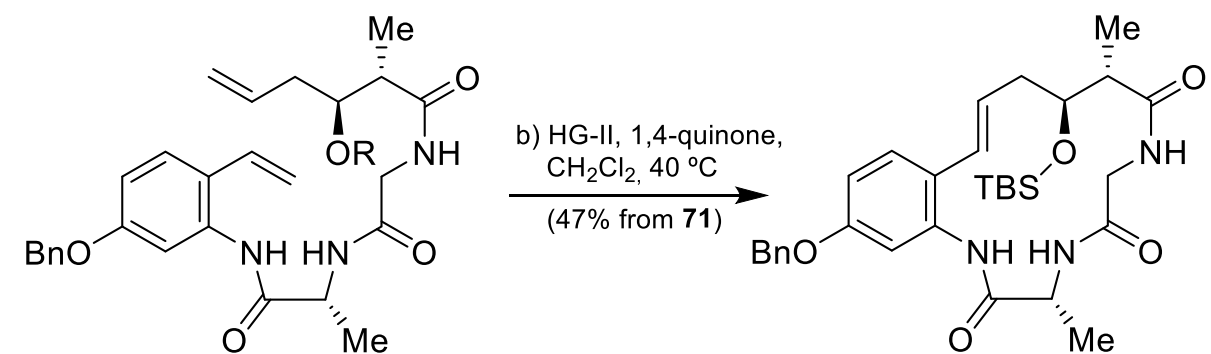

a) TBSOTf - 59: $\mathrm{R}=\mathrm{H}$ $(72 \%)$

71: $R=$ TBS

73: $R=T E S$ e) TESOTf 72 (53\% from 73) b) ${ }^{\mathrm{HG}-\mathrm{III}, 1,4-\text { quin }} \mathrm{CH}_{2} \mathrm{Cl}_{2}, 40^{\circ} \mathrm{C}$ $(68 \%)$

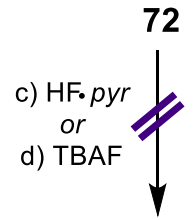<smiles>CSC/C=C\c1ccc(OCc2ccccc2)cc1NC(=O)C(C)NC(=O)CNC(=O)C(C)C</smiles>

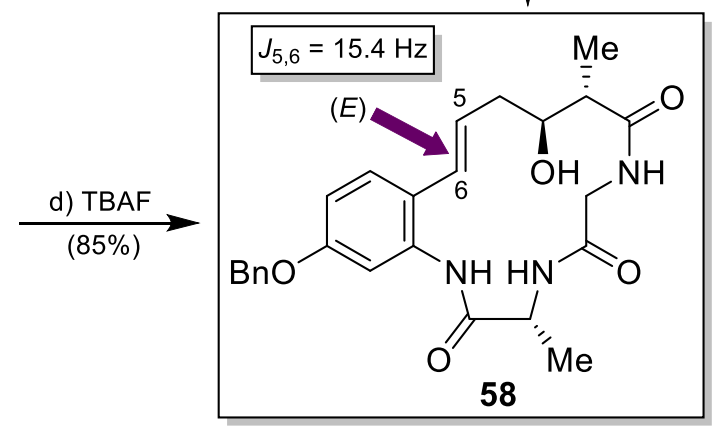

Scheme 11. RCM of the Acyclic Precursors 71 and 73: Synthesis of 58 
2.3. Ring-Closing Metathesis at the C3-C4 Bond. Prior to the completion of the synthetic study towards the natural solomonamides, for which meaningful quantities of $\mathbf{5 8}$ or precursor 74 were required, we opted to complete the exploration of the RCM reaction by exploring the C6-C7 bond as another disconnection point to construct the macrocyclic system of the solomonamides. This new disconnection strategy would be based on the retrosynthetic analysis depicted in Scheme 12. Having established the viability of the RCM strategy for the construction of the macrocylic core of the solomonamides at two different sites, the C5-C6 and the C4-C5 bonds, we decided to extend the RCM-based strategy to the $\mathrm{C} 3-\mathrm{C} 4$ position, scanning all the options along the six-carbons chain contained in the ADMOA fragment. In this new scenario, the removal of the functional groups at the $\mathrm{C} 3$ and $\mathrm{C} 4$ positions revealed the compound $\mathbf{7 5}$ as a potential precursor for solomonamide B, which could be obtained from the acyclic derivative 76 via RCM. In the synthetic direction, aldehyde $\mathbf{4 0}$ was transformed into the amine 79 without problems according to the synthetic sequence described in Scheme 12. Our experience gathered during the synthetic campaign led us to choose BOM as the most suitable protecting group for the benzylic alcohol and to introduce sequentially the two amino acids (D-Ala and Gly) through the Fmoc derivatives $\mathbf{3 4}$ and $\mathbf{3 5}$ to obtain compound $\mathbf{8 1}$. Prior to the preparation of the subtarget RCM precursor 76, we considered the use of the commercially available acid $\mathbf{8 2}$ to test the possibilities of this new strategy. Having prepared model compound 83, treatment with HG-II catalyst under similar reaction conditions as previously used, did not provide the desired result with the no formation of the macrocyclic compound 84. In fact, a rational explanation for this result could be the formation of a stable 5-membered ring chelate between the ruthenium carbene and the carbonyl group of the amide (intermediate A), which renders the metallacyclobutane intermediate unreactive toward the retro $[2+2]$ cycloaddition $^{28}$ (Scheme 12). At this stage, we decided to terminate this synthetic 
approach, taking into account that this strategy could be reconsidered in the future by use of Lewis acids ${ }^{29}$ which could be investigated as useful additives to promote the ring closure as has been demonstrated in cross-metathesis reactions bearing similar structural motifs.

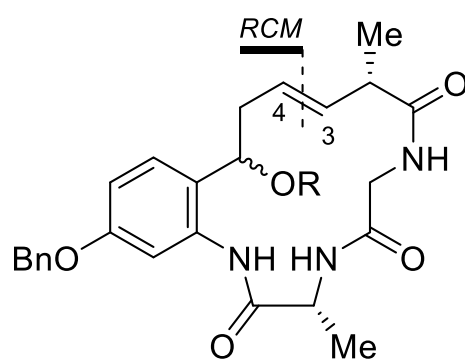

75: $\mathrm{R}=\mathrm{BOM}$

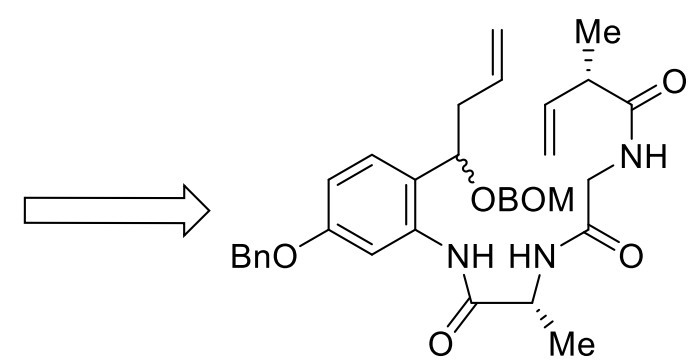

76
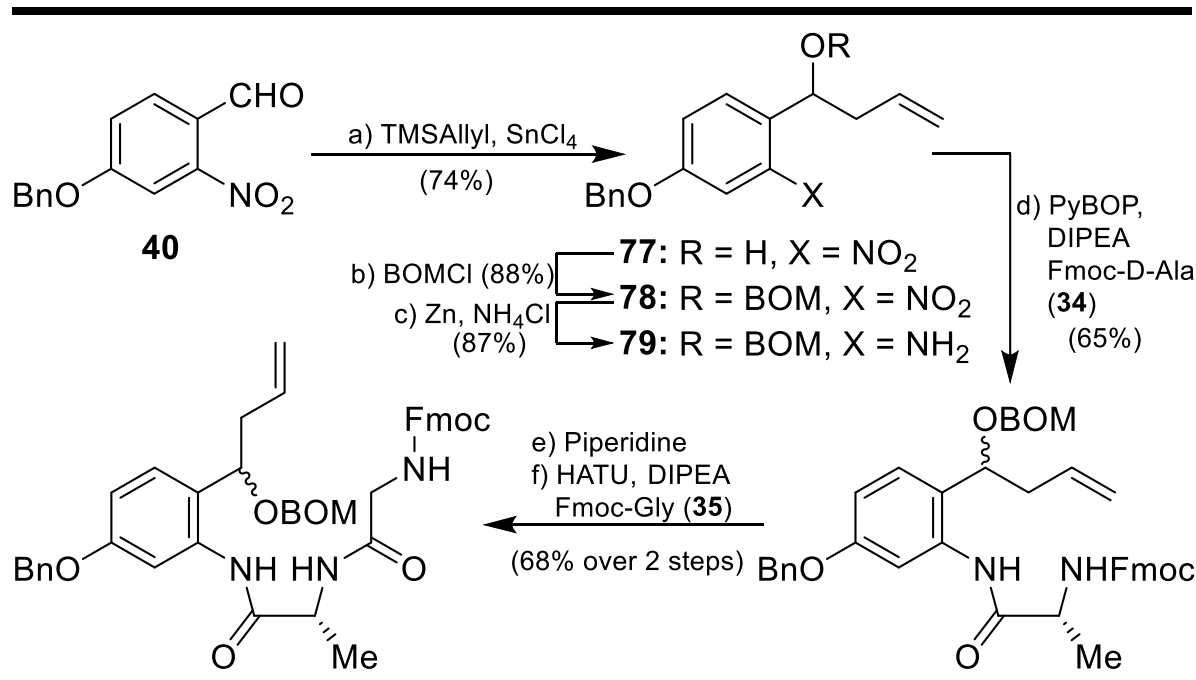

80

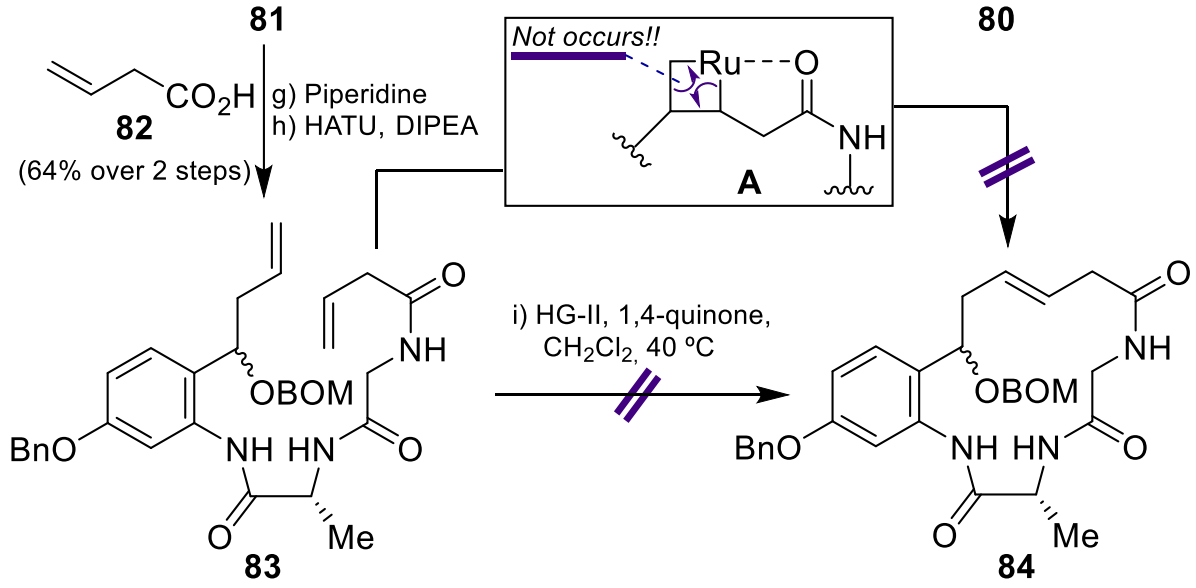

Scheme 12. Third Approach to the Solomonamides via RCM: The C3-C4 Disconnection 


\subsection{Biological Activity of Solomonamide Precursors.}

At this stage of the synthetic work, with an efficient route defined to obtain the final natural products, we were intrigued with the biological properties of the synthesized products, recognizing that the macrocyclic peptides represented unprecedented and novel molecular architectures of biological interest. For this reason, we decided to explore and investigate their biological activities. To this aim, we performed preliminary biological evaluations, which consisted of the measurement of the antitumor properties of selected compounds against a panel of various tumor cell lines. The chosen solomonamide derivatives for this study were 26, 27, 28, 38, 70, 74 and $\mathbf{5 8}$ as representative compounds of the different scaffolds generated during the synthetic work. In addition, compound $\mathbf{8 5}$, obtained from 27 by treatment with $\mathrm{Na} / \mathrm{NH}_{3}$ (See Figure 2), was included for this study to evaluate the effect of the protecting group upon biological activity.

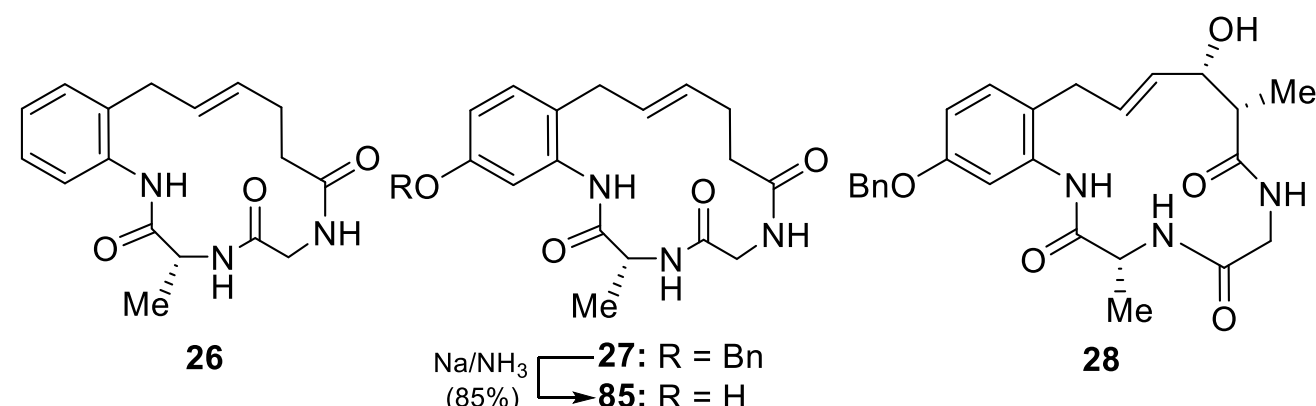<smiles>C[C@H](NC(=O)CNC(=O)CC/C=C/[C@H](O)c1ccccc1NC(=O)CO)C(=O)O</smiles>

38<smiles>CNC(=O)C(C)NC(=O)CNC(=O)CCC/C=C/c1ccc(OCc2ccccc2)cc1NC(C)C</smiles>

70<smiles>CNC(=O)C(C)C/C=C/c1ccc(OCc2ccccc2)cc1NC(=O)C(=O)NC(C)C(=O)NC(C)C</smiles>

74: $R=$ TES

58: $\mathrm{R}=\mathrm{H}$

Figure 2. Synthetic Solomonamide Precursors Submitted to Biological Evaluations 
As a first attempt to characterize the biological activities of the synthetic solomonamide analogues, the cytotoxicity profile of the aforementioned compounds was examined using nine different cancer cell lines (see Table 1), as well as a primary culture of non transformed bovine aorta endothelial (BAEC) cells. ${ }^{30}$ The results of these biological evaluations, summarized in Table 1, clearly revealed a relevant cytotoxic activity for only one compound, 58, which displayed the best values of inhibition of the series in the low $\mu \mathrm{M}$ range, against all the tumor cell lines. In addition, $\mathbf{5 8}$ was also cytotoxic against the endothelial cells line (BAEC), which may indicate a putative antiangiogenic effect of this compound. ${ }^{30}$ In contrast, the other compounds were practically devoid of antitumor activity except compounds $\mathbf{2 8}$ and 70, which displayed cytotoxicity, particularly against the HL60 tumor cell line albeit moderately. From these results, a highlight is the notable enhancement of activity observed upon introduction of functional groups in the polyketide fragment contained in these compounds, as concluded when biological activities of $\mathbf{7 0}$ and $\mathbf{5 8}$ are compared, or $\mathbf{2 7}$ and $\mathbf{2 8}$ for the case of the HL60 cell line. In addition, the isomeric derivative of $\mathbf{5 8}$, compound $\mathbf{2 8}$, displayed similar antiproliferative activity as $\mathbf{5 8}$ against HL60, but, in contrast, was inactive against the other cell lines, including BAEC, revealing the importance of the position of the double bond of the molecule upon biological activities. This structural effect is also reflected when the biological activities of the isomeric compounds $\mathbf{2 7}$ and $\mathbf{7 0}$ are compared. In an attempt to make sense of this result, molecular modelling studies were conducted for compounds $\mathbf{2 7 , 2 8 , 7 0}$ and $\mathbf{5 8}$ to obtain the corresponding minimized structures (Figure 3). ${ }^{31}$ The resulting models revealed a certain structural distorsion when 27 and 70, on one side, and $\mathbf{2 8}$ and 58, on the other, are compared, respectively. Thus, whereas $\mathbf{7 0}$ and $\mathbf{5 8}$ are almost flat, 27 and 28 displayed considerable twisting. These differences in the resulting minimized molecular structures may explain the differences observed for the biological activities found 
for these compounds. Additionally, the overall shape of $\mathbf{2 7}$ is very similar to $\mathbf{2 8}$, and the same is evident also for $\mathbf{7 0}$ and $\mathbf{5 8}$. In this case, despite these conformational similarities, it is clear that the functional groups incorporated in $\mathbf{2 8}$ and $\mathbf{5 8}$, in particular the hydroxyl group, may exert a key biological interaction through a hydrogen bonding interaction with an acceptortype residue located at the active site of the biological targets. These interactions may justify the greater activities displayed by $\mathbf{2 8}$ and $\mathbf{5 8}$ compared with $\mathbf{2 7}$ and $\mathbf{7 0}$, respectively.

Table 1. In vitro Antitumor Activities of Solomonamide Precursors against Various Tumor Cell Lines and BAEC $\left(\mathrm{IC}_{50}, \mu \mathrm{M}\right)^{\mathrm{a}}$

\begin{tabular}{|c|c|c|c|c|c|c|c|c|c|c|}
\hline Compound & HL60 ${ }^{b}$ & KU812Fc & U937 & HT-1080 & $\begin{array}{l}\text { MDA- } \\
\text { MB-231 }^{f}\end{array}$ & U87MGg & HepG $^{\text {h }}$ & HT-29i & U2OS $^{j}$ & BAEC $^{k}$ \\
\hline 26 & $>50$ & $>50$ & $>50$ & $>100$ & $>100$ & $>100$ & $>100$ & $>100$ & $>100$ & $>100$ \\
\hline 27 & $>50$ & n.d. & n.d. & $>100$ & $>100$ & $>100$ & $>100$ & $>100$ & $>100$ & $43,8 \pm 1,2$ \\
\hline 85 & $>50$ & $>50$ & $>50$ & $>100$ & $>100$ & $>100$ & $>100$ & $>100$ & $>100$ & $>100$ \\
\hline 28 & $17,2 \pm 6,6$ & n.d. & n.d. & $>50$ & $>50$ & n.d. & n.d. & n.d. & n.d. & $>100$ \\
\hline 38 & $>50$ & $>50$ & $>50$ & $>100$ & $>100$ & $>100$ & $>100$ & $>100$ & $>100$ & $>100$ \\
\hline 70 & $20,5 \pm 5.2$ & $>50$ & $>50$ & $31,1 \pm 2,8$ & $>100$ & $>100$ & $>100$ & $>100$ & $>100$ & $69,6 \pm 12,5$ \\
\hline 74 & $>50$ & $>50$ & $>50$ & $>100$ & $>100$ & $>100$ & $>100$ & $>100$ & $>100$ & $>100$ \\
\hline 58 & $14,7 \pm 4,4$ & $14,0 \pm 3.05$ & $7,02 \pm 2.32$ & $16,3 \pm 2.9$ & $16,5 \pm 1,01$ & $34,8 \pm 5,1$ & $18,9 \pm 1,5$ & $13,3 \pm 0,6$ & $12,9 \pm 3,1$ & $18,1 \pm 2,2$ \\
\hline
\end{tabular}

[a] In vitro cytotoxicities were determined according to the 3-(4,5-dimethylthiazol-2-yl)-2,5-diphenyltetrazolium bromide dye reduction assay as detailed in experimental part. The $\mathrm{IC}_{50}$ values were obtained from semilogarithmic dose-response plots as the concentration of compound yielding a 50\% of cell survival. [b] HL60: Human promyelocytic leukemia. [c] KU812F: Chronic Myelogenous leukemia. [d] U937: Histiocytic lymphoma. [e] HT1080: Human fibrosarcoma. [f] MDA-MB-231: Human breast adenocarcinoma. [g] U87MG: Gioblastoma. [h] HepG2: Hepatocellular carcinoma. [i] HT-29: Colorectal adenocarcinoma. [j] U2OS: Osteosarcoma. [k] BAEC: Non transformed bovine aortic endothelial cells. 

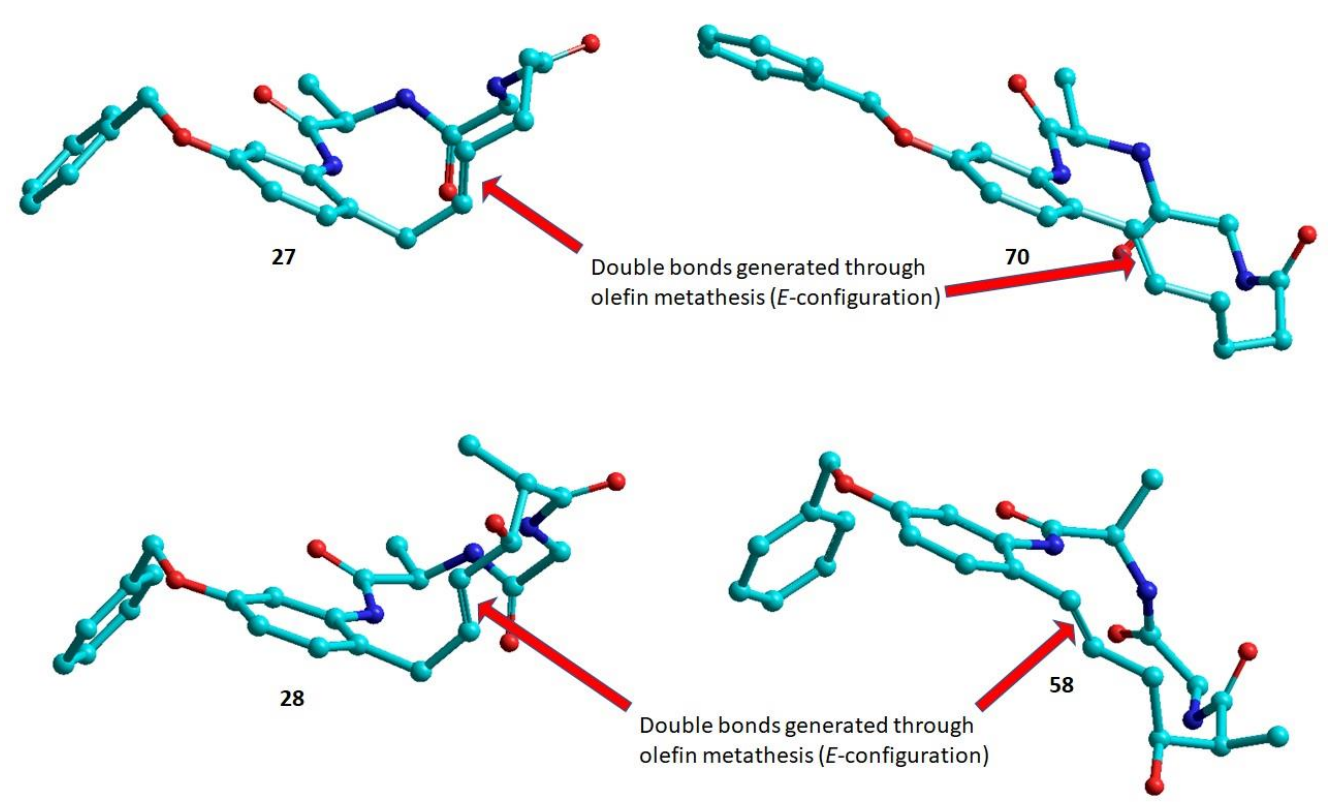

Figure 3. Computer-generated Minimum-Energy Conformations for Compounds 27, 28, 58 and 70

\section{CONCLUSIONS}

In conclusion, an extensive synthetic exploration directed towards the solomonamides was conducted based on a ring-closing metathesis as the key reaction for the rapid and efficient access to their macrocyclic cores. The result of this synthetic study was the establishment of an efficient ring closure process which proceeded in high yields and complete stereoselectivity. During the course of these efforts, unexpected hurdles arose along the way, mainly with: 1) the reactivity of the hydroxyl group at the benzylic position (compounds 31 and $\mathbf{4 1}$ ); 2) the reactivity of diolefins containing allylic and homoallylic alcohols (compounds 7, 8, 32, 47, 59, 63, 71 and 73) or containing a $\beta, \gamma-$ unsaturated carbonyl system (case of compound 83) toward the ruthenium catalysts, and 3) the reactivity of macrocyclic olefins (compounds 27, 28 and 48) toward oxidative reagents. Although many of these synthetic problems were overcome, others remained elusive and represent synthetic challenges for future works. In relation to the 
ring-closing metathesis reactions, many of the described findings support the observations and results reported by other authors for this reaction on this class of structural systems. More importantly, not only did we explore the scope and limitations of the ring-closing metathesis in the synthesis of the macrocyclic core of the solomonamides, but we also identified several structurally related solomonamide precursors possessing significant cytotoxicities against various tumor cell lines, including endothelial cells, in the low $\mu \mathrm{M}$ range. These preliminary biological evaluations of relatively simple compounds, devoid of the functional groups present in the natural counterparts, portend promising antitumor properties for the natural products and qualify them as new scaffolds of biological and medicinal interest. Therefore, the described chemistry highlights the benefits of the olefin metathesis reaction in the field of the total synthesis of natural products, featuring convergency and flexibility for structural diversity and has allowed the identification of bioactive compounds with interesting antitumor properties. The completion of the synthesis of the natural products, the design of new analogues based upon compound 58, and further biological studies to elucidate the mechanism of its antitumoral and antiangiogenic activities are currently in progress and they will be reported in due course.

\section{EXPERIMENTAL SECTION}

General Techniques. All reactions were carried out under an argon atmosphere with dry, freshly distilled solvents under anhydrous conditions, unless using aqueous reagents or otherwise noted. All solvents used in reactions were dried and distilled using standard procedures. Tetrahydrofuran (THF) was distilled from sodium benzophenone, and methylene 
chloride $\left(\mathrm{CH}_{2} \mathrm{Cl}_{2}\right)$ from calcium hydride. Yields refer to chromatographically and spectroscopically $\left({ }^{1} \mathrm{H}\right.$ NMR) homogeneous materials, unless otherwise stated. All solutions used in workup procedures were saturated unless otherwise noted. All reagents were purchased at highest commercial quality and used without further purification unless otherwise stated. All reactions were monitored by thin-layer chromatography (TLC) using $0.25 \mathrm{~mm}$ silica gel plates (60F-254) using UV light $(254 \mathrm{~nm})$ as visualizing agent and acidic ceric ammonium molybdate/ phosphomolybdic acid or potassium permanganate solutions and heat as developing agents. Flash column chromatography (FCC) was performed using silica gel (60 A, particle size 230-400 mesh) under air pressure. All solvents used for chromatographic purifications were distilled prior to use. ${ }^{1} \mathrm{H}$ and ${ }^{13} \mathrm{C}$ NMR spectra were recorded on a Bruker DPX-400 MHz instrument and calibrated using residual undeuterated solvent as an internal reference. Chemical shifts are reported in ppm with the resonance resulting from incomplete deuteration of the solvent as the internal standard $\left({ }^{13} \mathrm{CDCl}_{3}: 7.26\right.$ ppm, s and 77.0 ppm, t; ${ }^{13} \mathrm{CD}_{3} \mathrm{OD}: 4.87 \mathrm{ppm}, \mathrm{s}, 3.31 \mathrm{ppm}$, quin and $49.1 \mathrm{ppm}$, sep; ${ }^{13} \mathrm{C}_{2} \mathrm{D}_{6} \mathrm{OS}$ : $2.49 \mathrm{ppm}$, quin and $39.52 \mathrm{ppm}$, sep). Data are reported as follows: chemical shift $\delta / \mathrm{ppm}$ (multiplicity, coupling constants $J(\mathrm{~Hz})$ and integration $\left({ }^{1} \mathrm{H}\right.$ only)). The following abbreviations were used to explain the multiplicities: $\mathrm{s}=$ singlet; $\mathrm{d}=$ doublet; $\mathrm{t}=$ triplet; $\mathrm{q}=$ quartet; quin $=$ quintet $; \mathrm{b}=$ broad $; \mathrm{m}=$ multiplet or combination thereof. ${ }^{13} \mathrm{C}$ signals are singles, unless otherwise stated. High resolution mass spectrometry (HRMS) was performed on a H-ESI and APCI mass spectrometer in positive mode and using an ion trap (Orbitrap) as the mass analyzer type. HRMS signals are reported to 4 decimal places and are within \pm 5 ppm of theoretical values. Specific optical rotations were recorded on a Perkin-Elmer 241 polarimeter with a sodium halogen lamp $(\chi=589 \mathrm{~nm})$ and a cell path length of $100 \mathrm{~mm}(c$ 
given in $\mathrm{g} / 100 \mathrm{~mL}$ ). Melting points were collected using a Gallenkamp or a Griffin melting point system using a gradient of $0.5^{\circ} \mathrm{C}$ per min.

Biological Material and Methods. Bovine aortic endothelial cells (BAEC) were isolated by collagenase digestion, as previously described, ${ }^{30}$ and maintained in Dulbecco's modified Eagle's medium (DMEM) containing glucose (1 g/L) supplemented with $10 \%$ FBS (DMEM/10\% FBS). All the cancer cell lines used in this study were obtained from the American Type Culture Collection (ATCC). Human fibrosarcoma HT-1080, hepatocellular carcinoma HepG2 and glioblastoma U87MG cells were maintained in Eagle's Minimum Essential Medium (EMEM) supplemented with 10\% FBS. Human colon adenocarcinoma HT29 cells and human osteosarcoma U2OS cells were maintained in DMEM containing glucose (4,5 g/L) supplemented with 10\% FBS. Human breast cancer carcinoma MDA-MB-231, chronic myelogenous leukemia KU812F and histiocytic lymphoma U937 cells were maintained in RPMI1640 medium supplemented with 10\% FBS. Acute promyelocytic leukemia HL-60 cells were maintained in RPMI1640 medium supplemented with 20\% FBS. All culture medium contained glutamine $(2 \mathrm{mM})$, penicillin $(50 \mathrm{IU} / \mathrm{mL})$, streptomycin $(50$ $\mu \mathrm{g} / \mathrm{mL})$ and amphotericin $(1.25 \mu \mathrm{g} / \mathrm{mL})$ and all cell lines were grown at $37{ }^{\circ} \mathrm{C}$ and humidified $5 \% \mathrm{CO}_{2}$ atmosphere.

Aniline 19. To a solution of bromoaniline $17\left(1.0 \mathrm{~g}, 5.81 \mathrm{mmol}, 1.0\right.$ equiv) and $\mathrm{Pd}\left[\mathrm{PPh}_{3}\right]_{4}$ (336 mg, $0.29 \mathrm{mmol}, 0.05$ equiv) in DMF (15 mL) was added dropwise allyltri- $n$-butyltin (2.2 $\mathrm{mL}, 6.97 \mathrm{mmol}, 1.2$ equiv). The solution was then heated at $80{ }^{\circ} \mathrm{C}$ for $12 \mathrm{~h}$. After this time, the mixture was diluted with diethyl ether and washed with water. The organic layer was separated and washed with water four times, dried over anhydrous $\mathrm{MgSO}_{4}$, filtered and the solvent evaporated under reduced pressure. The crude product was purified by flash column 
chromatography (silica gel, 5\% EtOAc in hexanes) to obtain aniline 19 (596 mg, 77\%) as a yellow oil: $\mathrm{R}_{f}=0.60$ (silica gel, 20\% EtOAc in hexanes); ${ }^{1} \mathrm{H}$ NMR (400 $\left.\mathrm{MHz}, \mathrm{CDCl}_{3}\right) \delta$ (ppm) $7.13-7.05(\mathrm{~m}, 2 \mathrm{H}), 6.78(\mathrm{td}, J=7.4,1.1 \mathrm{~Hz}, 1 \mathrm{H}), 6.72-6.69(\mathrm{~m}, 1 \mathrm{H}), 6.04-5.92$ (m, $1 \mathrm{H}), 5.18-5.09(\mathrm{~m}, 2 \mathrm{H}), 3.64(\mathrm{bs}, 2 \mathrm{H}), 3.33(\mathrm{~d}, J=6.1 \mathrm{~Hz}, 2 \mathrm{H}) ;{ }^{13} \mathrm{C}$ NMR $(100 \mathrm{MHz}$, $\left.\mathrm{CDCl}_{3}\right) \delta(\mathrm{ppm}) 144.8,136.0,130.2,127.6,124.0,118.9,116.1,115.9,36.5 ;$ HRMS (H-ESI) $m / z:[\mathrm{M}+\mathrm{H}]^{+}$calcd for $\mathrm{C}_{9} \mathrm{H}_{12} \mathrm{~N}$ 134.0970; found 134.0967.

Aniline 20. To a solution of iodonitrobenzene $\mathbf{1 8}^{11}(6.0 \mathrm{~g}, 16.90 \mathrm{mmol}, 1.0$ equiv) and $\mathrm{Pd}\left[\mathrm{PPh}_{3}\right]_{4}(3.0 \mathrm{~g}, 3.40 \mathrm{mmol}, 0.15$ equiv) in DMF (30 mL) was added dropwise allyltri- $n$ butyltin (6.4 mL, $20.30 \mathrm{mmol}, 1.2$ equiv). The solution was then heated at $60{ }^{\circ} \mathrm{C}$ for $15 \mathrm{~h}$. After this time, the mixture was diluted with $\mathrm{Et}_{2} \mathrm{O}$ and water. The organic layer was separated and washed with water four times, dried over anhydrous $\mathrm{MgSO}_{4}$, filtered and the solvent evaporated under reduced pressure. The crude product was purified by flash column chromatography (silica gel, 100\% Hexanes) to obtain the corresponding allyl derivative ( $3.3 \mathrm{~g}$, $73 \%$ ) as a yellow oil: $\mathrm{R}_{f}=0.56$ (silica gel, $20 \%$ EtOAc in hexanes); ${ }^{1} \mathrm{H}$ NMR (400 MHz, $\left.\mathrm{CDCl}_{3}\right) \delta(\mathrm{ppm}) 7.54(\mathrm{~d}, J=2.7 \mathrm{~Hz}, 1 \mathrm{H}), 7.46-7.33(\mathrm{~m}, 5 \mathrm{H}), 7.28-7.25(\mathrm{~m}, 1 \mathrm{H}), 7.16$ $(\mathrm{dd}, J=8.5,2.7 \mathrm{~Hz}, 1 \mathrm{H}), 5.96(\mathrm{ddt}, J=16.6,10.1,6.4 \mathrm{~Hz}, 1 \mathrm{H}), 5.11(\mathrm{~s}, 2 \mathrm{H}), 5.09-5.07$ (m, $1 \mathrm{H}), 5.05-5.03(\mathrm{~m}, 1 \mathrm{H}), 3.62(\mathrm{dt}, J=6.4,1.4 \mathrm{~Hz}, 2 \mathrm{H}) ;{ }^{13} \mathrm{C} \mathrm{NMR}\left(100 \mathrm{MHz}, \mathrm{CDCl}_{3}\right) \delta$ (ppm) 157.4, 135.8, 135.4, 132.8, 128.7, 128.3, 127.5, 127.1, 120.4, 116.7, 110.3, 70.6, 36.3; HRMS (H-ESI) $m / z$ : $[\mathrm{M}+\mathrm{H}]^{+}$calcd for $\mathrm{C}_{16} \mathrm{H}_{16} \mathrm{NO}_{3} 270.1130$; found 270.1129. To a solution of the allyl derivative obtained above $(1.5 \mathrm{~g}, 5.60 \mathrm{mmol}, 1.0$ equiv) in acetic acid $(15 \mathrm{~mL})$ was added $\mathrm{Zn}$ dust (1.0 g, $16.20 \mathrm{mmol}, 3.0$ equiv) in ten portions of $100 \mathrm{mg}$ each over $30 \mathrm{~min}$ at $25^{\circ} \mathrm{C}$. The reaction mixture was stirred at this temperature until completion monitoring by TLC $(1 \mathrm{~h})$ and then, quenched by addition of $10 \% \mathrm{NaOH}$ solution at $0{ }^{\circ} \mathrm{C}$. The mixture was 
extracted with $\mathrm{CH}_{2} \mathrm{Cl}_{2}$, and the organic phase washed with water, dried over anhydrous $\mathrm{MgSO}_{4}$, filtered and the solvent evaporated under reduced pressure. The resulting residue was purified by flash column chromatography (silica gel, 5\% EtOAc in hexanes) to obtain 20 (773 mg, 65\%) as an orange oil: $\mathrm{R}_{f}=0.38$ (silica gel, 20\% EtOAc in hexanes); ${ }^{1} \mathrm{H}$ NMR (400 MHz, $\left.\mathrm{CDCl}_{3}\right) \delta(\mathrm{ppm}) 7.46-7.37(\mathrm{~m}, 4 \mathrm{H}), 7.35-7.30(\mathrm{~m}, 1 \mathrm{H}), 6.95(\mathrm{~d}, J=8.3 \mathrm{~Hz}, 1 \mathrm{H}), 6.41$ $(\mathrm{dd}, J=8.2,2.5 \mathrm{~Hz}, 1 \mathrm{H}), 6.35(\mathrm{~d}, J=2.5 \mathrm{~Hz}, 1 \mathrm{H}), 5.95(\mathrm{ddt}, J=16.6,10.5,6.1 \mathrm{~Hz}, 1 \mathrm{H})$, $5.14-5.11(\mathrm{~m}, 1 \mathrm{H}), 5.11-5.08(\mathrm{~m}, 1 \mathrm{H}), 5.03(\mathrm{~s}, 2 \mathrm{H}), 3.67(\mathrm{bs}, 2 \mathrm{H}), 3.26(\mathrm{dt}, J=6.1,1.5$ $\mathrm{Hz}, 2 \mathrm{H}) ;{ }^{13} \mathrm{C} \mathrm{NMR}\left(100 \mathrm{MHz}, \mathrm{CDCl}_{3}\right) \delta(\mathrm{ppm}) 158.6,145.8,137.3,136.4,130.9,128.5$, 127.8, 127.4, 116.9, 115.8, 104.9, 102.6, 69.9, 35.8; HRMS (H-ESI) $m / z:[\mathrm{M}+\mathrm{H}]^{+}$calcd for $\mathrm{C}_{16} \mathrm{H}_{18} \mathrm{NO} 240.1388$; found 240.1392.

Dipeptide 22. To a solution of aniline 19 (700 mg, $5.25 \mathrm{mmol}, 1.0$ equiv) and Boc-Gly-DAla-OH (21) $)^{12}(1.3 \mathrm{~g}, 5.25 \mathrm{mmol}, 1.0$ equiv) in DMF (15 mL) was added HATU (3.0 g, 7.88 mmol, 1.5 equiv) and DIPEA (1.0 mL, $5.25 \mathrm{mmol}, 1.0$ equiv) at $0{ }^{\circ} \mathrm{C}$ and the mixture was stirred for $12 \mathrm{~h}$ at $25^{\circ} \mathrm{C}$. After this time, a saturated aqueous $\mathrm{NH}_{4} \mathrm{Cl}$ solution was added and the organic layer was separated. The aqueous phase was extracted with EtOAc, and the combined organic layers were washed with brine, dried over anhydrous $\mathrm{MgSO}_{4}$, filtered and the solvent evaporated under reduced pressure. The crude product was purified by flash column chromatography (silica gel, 20\% EtOAc in hexanes $\rightarrow 50 \%$ EtOAc in hexanes) to obtain dipeptide $22(1.5 \mathrm{~g}, 81 \%)$ as a white foam: $\mathrm{R}_{f}=0.60$ (silica gel, 100\% EtOAc); $[\alpha]^{25} \mathrm{D}$ $=-6.23\left(c 0.45, \mathrm{CH}_{2} \mathrm{Cl}_{2}\right) ;{ }^{1} \mathrm{H} \mathrm{NMR}\left(400 \mathrm{MHz}, \mathrm{CDCl}_{3}\right) \delta(\mathrm{ppm}) 7.96$ (bs, $\left.1 \mathrm{H}\right), 7.79(\mathrm{~d}, J=$ 8.0 Hz, $1 \mathrm{H}), 7.23(\mathrm{dd}, J=8.1,1.7 \mathrm{~Hz}, 1 \mathrm{H}), 7.18(\mathrm{dd}, J=7.5,1.5 \mathrm{~Hz}, 1 \mathrm{H}), 7.15-7.10(\mathrm{~m}, 1$ H), $6.87(\mathrm{~s}, 1 \mathrm{H}), 5.97(\mathrm{ddt}, J=16.2,10.2,6.0 \mathrm{~Hz}, 1 \mathrm{H}), 5.15(\mathrm{dd}, J=10.2,1.6 \mathrm{~Hz}, 1 \mathrm{H}), 5.06$ $(\mathrm{dd}, J=17.2,1.6 \mathrm{~Hz}, 1 \mathrm{H}), 4.64-4.55(\mathrm{~m}, 1 \mathrm{H}), 3.88-3.80(\mathrm{~m}, 2 \mathrm{H}), 3.41-3.33(\mathrm{~m}, 2 \mathrm{H})$, 
$1.47(\mathrm{~d}, J=7.0 \mathrm{~Hz}, 3 \mathrm{H}), 1.44(\mathrm{~s}, 9 \mathrm{H}) ;{ }^{13} \mathrm{C} \mathrm{NMR}\left(100 \mathrm{MHz}, \mathrm{CDCl}_{3}\right) \delta(\mathrm{ppm}) 170.4,170.0$ $156.2,135.9,135.4,131.1,130.2,127.1,125.8,123.9,116.5,49.5,38.7,36.1,31.3,28.3$, 17.8; HRMS (H-ESI) $m / z$ : $[\mathrm{M}+\mathrm{H}]^{+}$calcd for $\mathrm{C}_{19} \mathrm{H}_{28} \mathrm{~N}_{3} \mathrm{O}_{4}$ 362.2080; found 362.2079.

Dipeptide 11. To a solution of aniline 20 (730 mg, $3.10 \mathrm{mmol}, 1.0$ equiv) and Boc-Gly-DAla-OH (21) (752 mg, $3.10 \mathrm{mmol}, 1.0$ equiv) in $\mathrm{CH}_{2} \mathrm{Cl}_{2}(15 \mathrm{~mL})$ was added HATU (1.7 g, $4.60 \mathrm{mmol}, 1.5$ equiv) and DIPEA ( $0.5 \mathrm{~mL}, 3.10 \mathrm{mmol}, 1.0$ equiv) and the mixture was stirred for $12 \mathrm{~h}$ at $25{ }^{\circ} \mathrm{C}$. After this time, the reaction mixture was diluted with $\mathrm{CH}_{2} \mathrm{Cl}_{2}$ and washed sequentially with $1 \mathrm{~N} \mathrm{HCl}$ and a saturated aqueous $\mathrm{NaHCO}_{3}$ solution. The organic layer was separated, washed with brine, dried over anhydrous $\mathrm{MgSO}_{4}$, filtered and the solvent evaporated under reduced pressure. The crude product was purified by flash column chromatography (silica gel, 20\% EtOAc in hexanes) to obtain dipeptide $\mathbf{1 1}(1.15 \mathrm{~g}, 81 \%)$ as a pale brown solid: $\mathrm{R}_{f}=0.69$ (silica gel, $100 \%$ EtOAc); $[\alpha]^{25} \mathrm{D}=-3.41\left(c 0.10, \mathrm{CH}_{2} \mathrm{Cl}_{2}\right) ; \mathrm{mp}=$ 83-84 ${ }^{\circ} \mathrm{C} ;{ }^{1} \mathrm{H}$ NMR $\left(400 \mathrm{MHz}, \mathrm{CDCl}_{3}\right) \delta(\mathrm{ppm}) 8.07$ (bs, $\left.1 \mathrm{H}\right), 7.62(\mathrm{~d}, J=2.3 \mathrm{~Hz}, 1 \mathrm{H}), 7.44$ $-7.27(\mathrm{~m}, 6 \mathrm{H}), 7.05(\mathrm{~d}, J=8.5 \mathrm{~Hz}, 1 \mathrm{H}), 6.94(\mathrm{~d}, J=7.3 \mathrm{~Hz}, 1 \mathrm{H}), 6.73(\mathrm{dd}, J=8.4,2.6 \mathrm{~Hz}$, $1 \mathrm{H}), 5.94$ (ddt, $J=16.2,10.2,5.9 \mathrm{~Hz}, 1 \mathrm{H}), 5.14-5.04(\mathrm{~m}, 2 \mathrm{H}), 5.02(\mathrm{~s}, 2 \mathrm{H}), 4.59$ (p, $J=$ $7.0 \mathrm{~Hz}, 1 \mathrm{H}), 3.91-3.77$ (m, $2 \mathrm{H}), 3.37-3.23(\mathrm{~m}, 2 \mathrm{H}), 1.46(\mathrm{~d}, J=7.0 \mathrm{~Hz}, 3 \mathrm{H}), 1.44$ (s, 9 $\mathrm{H}) ;{ }^{13} \mathrm{C} \mathrm{NMR}\left(100 \mathrm{MHz}, \mathrm{CDCl}_{3}\right) \delta(\mathrm{ppm}) 170.1,169.9,157.9,156.0,136.9,136.3,130.8$, $128.5,127.9,127.7,127.5,122.3,116.2,112.2,109.4,80.6,70.0,49.6,39.2,36.5,28.2,17.6$; HRMS (H-ESI) $m / z:[\mathrm{M}+\mathrm{H}]^{+}$calcd for $\mathrm{C}_{26} \mathrm{H}_{34} \mathrm{~N}_{3} \mathrm{O}_{5} 468.2498$; found 468.2487.

Diolefin 24. TFA (5.0 mL) was added to a solution of dipeptide 22 (360 mg, $0.99 \mathrm{mmol}, 1.0$ equiv) in $\mathrm{CH}_{2} \mathrm{Cl}_{2}(60 \mathrm{~mL})$ at $0{ }^{\circ} \mathrm{C}$ and the reaction mixture was stirred at $25^{\circ} \mathrm{C}$ until depletion of starting material as judged by TLC $(3 \mathrm{~h})$. Then, the TFA excess was removed under 
reduced pressure to obtain the corresponding ammonium trifluoroacetate salt as a brown solid which was dissolved in DMF (10 mL). To this solution, Kosher acid 23 (0.1 mL, 0.99 mmol, 1.0 equiv), HATU (379 mg, $0.99 \mathrm{mmol}, 1.0$ equiv) and DIPEA (0.52 mL, $2.99 \mathrm{mmol}, 3.0$ equiv) were added and the resulting solution was stirred at $25^{\circ} \mathrm{C}$ for $12 \mathrm{~h}$. After this time, a saturated aqueous $\mathrm{NH}_{4} \mathrm{Cl}$ solution was added and the organic layer was separated. The aqueous phase was extracted with EtOAc, and the combined organic layers were washed with brine, dried over anhydrous $\mathrm{MgSO}_{4}$, filtered and the solvent evaporated under reduced pressure. The resulting residue was purified by flash column chromatography (silica gel, 30\% EtOAc in hexanes) to obtain diolefin $\mathbf{2 4}$ (205 $\mathrm{mg}$, $60 \%$ over two steps) as a white solid: $\mathrm{R}_{f}=$ 0.23 (silica gel, $100 \%$ EtOAc); $[\alpha]^{25} \mathrm{D}=-8.50\left(c 0.51, \mathrm{CH}_{2} \mathrm{Cl}_{2}\right) ; \mathrm{mp}=80-81{ }^{\circ} \mathrm{C} ;{ }^{1} \mathrm{H} \mathrm{NMR}$ $\left(400 \mathrm{MHz}, \mathrm{CDCl}_{3}\right) \delta(\mathrm{ppm}) 7.82(\mathrm{bs}, 1 \mathrm{H}), 7.29-7.27(\mathrm{~m}, 1 \mathrm{H}), 7.25-7.23(\mathrm{~m}, 1 \mathrm{H}), 7.21-$ $7.17(\mathrm{~m}, 1 \mathrm{H}), 7.16-7.11(\mathrm{~m}, 1 \mathrm{H}), 6.64(\mathrm{~d}, J=6.4 \mathrm{~Hz}, 1 \mathrm{H}), 6.17(\mathrm{bs}, 1 \mathrm{H}), 5.98$ (dt, $J=$ 16.4, $6.3 \mathrm{~Hz}, 1 \mathrm{H}), 5.83(\mathrm{dt}, J=16.9,5.8 \mathrm{~Hz}, 1 \mathrm{H}), 5.19-5.14(\mathrm{~m}, 1 \mathrm{H}), 5.12-5.09(\mathrm{~m}, 1 \mathrm{H})$, $5.08-5.01(\mathrm{~m}, 2 \mathrm{H}), 4.60-4.51(\mathrm{~m}, 1 \mathrm{H}), 3.98(\mathrm{~d}, J=5.4 \mathrm{~Hz}, 2 \mathrm{H}), 3.41-3.35(\mathrm{~m}, 2 \mathrm{H})$, $2.44-2.33(\mathrm{~m}, 4 \mathrm{H}), 1.48(\mathrm{~d}, J=7.0 \mathrm{~Hz}, 3 \mathrm{H}) ;{ }^{13} \mathrm{C} \mathrm{NMR}\left(100 \mathrm{MHz}, \mathrm{CDCl}_{3}\right) \delta(\mathrm{ppm}) 173.1$, $169.9,169.1,136.7,136.0,135.3,130.4,130.3,127.4,125.7,123.6,116.6,115.9,49.7,43.1$, 36.4, 35.4, 29.4, 17.9; HRMS (H-ESI) $m / z:[\mathrm{M}+\mathrm{H}]^{+}$calcd for $\mathrm{C}_{19} \mathrm{H}_{26} \mathrm{~N}_{3} \mathrm{O}_{3}$ 344.1974; found 344.1965 .

Diolefin 25. Dipeptide 11 (150 mg, $0.32 \mathrm{mmol}, 1.0$ equiv) in $\mathrm{CH}_{2} \mathrm{Cl}_{2}(20 \mathrm{~mL})$ was treated with TFA $(1.6 \mathrm{~mL})$ in exactly the same manner as previously described for synthesis of $\mathbf{2 4}$. A solution of the ammonium salt and Kosher acid $23\left(30 \mu \mathrm{L}, 0.32 \mathrm{mmol}, 1.0\right.$ equiv), in $\mathrm{CH}_{2} \mathrm{Cl}_{2}$ $(10 \mathrm{~mL})$ was treated with HATU $(122 \mathrm{mg}, 0.32 \mathrm{mmol}, 1.0$ equiv) and DIPEA $(0.17 \mathrm{~mL}, 0.96$ mmol, 3.0 equiv) and the resulting solution was stirred at $25{ }^{\circ} \mathrm{C}$ for $12 \mathrm{~h}$. After this time, a 
saturated aqueous $\mathrm{NH}_{4} \mathrm{Cl}$ solution was added and the organic layer was separated. The aqueous phase was extracted with EtOAc, and the combined organic layers were washed with brine, dried over anhydrous $\mathrm{MgSO}_{4}$, filtered and the solvent evaporated under reduced pressure. The resulting residue was purified by flash column chromatography (silica gel, 20\% EtOAc in hexanes $\rightarrow$ 80\% EtOAc in hexanes) to obtain diolefin 25 (140 mg, 97\% over two steps) as a white solid: $\mathrm{R}_{f}=0.24$ (silica gel, $\left.100 \%\right) ;[\alpha]^{25} \mathrm{D}=-6.37\left(c 0.06, \mathrm{CH}_{2} \mathrm{Cl}_{2}\right) ; \mathrm{mp}=$ 87-88 ${ }^{\circ} \mathrm{C} ;{ }^{1} \mathrm{H}$ NMR $\left(400 \mathrm{MHz}, \mathrm{CDCl}_{3}\right) \delta(\mathrm{ppm}) 8.02$ (bs, $\left.1 \mathrm{H}\right), 7.63$ (bs, $\left.1 \mathrm{H}\right), 7.45-7.28$ (m, $6 \mathrm{H}), 7.05(\mathrm{~d}, J=8.5 \mathrm{~Hz}, 1 \mathrm{H}), 6.74(\mathrm{dd}, J=8.4,2.6 \mathrm{~Hz}, 1 \mathrm{H}), 6.43$ (bs, $1 \mathrm{H}), 5.94$ (ddd, $J=$ 16.5, 11.1, $5.8 \mathrm{~Hz}, 1 \mathrm{H}), 5.81(\mathrm{ddd}, J=17.0,11.2,6.2 \mathrm{~Hz}, 1 \mathrm{H}), 5.15-5.04(\mathrm{~m}, 4 \mathrm{H}), 5.03$ (s, $2 \mathrm{H}), 4.60-4.52(\mathrm{~m}, 1 \mathrm{H}), 4.04-3.93(\mathrm{~m}, 2 \mathrm{H}), 3.37-3.24(\mathrm{~m}, 2 \mathrm{H}), 2.43-2.31(\mathrm{~m}, 4 \mathrm{H})$, $1.46(\mathrm{~d}, J=7.0 \mathrm{~Hz}, 3 \mathrm{H}) ;{ }^{13} \mathrm{C} \mathrm{NMR}\left(100 \mathrm{MHz}, \mathrm{CDCl}_{3}\right) \delta(\mathrm{ppm}) 173.5,170.8,169.5,157.7$, $136.9,136.7,136.3,136.0,130.7,128.5,127.9,127.5,123.6,116.1,115.6,112.2,110.4,70.0$ 49.8, 43.1, 38.6, 36.2, 36.1, 29.3, 17.7; HRMS (H-ESI) $m / z:[\mathrm{M}+\mathrm{H}]^{+}$calcd for $\mathrm{C}_{26} \mathrm{H}_{32} \mathrm{~N}_{3} \mathrm{O}_{4}$ 450.2393; found 450.2390 .

Macrocycle 26. Diolefin 24 (45 mg, $0.13 \mathrm{mmol}, 1.0$ equiv), Hoveyda-Grubbs $2^{\text {nd }}$ generation catalyst ( $8 \mathrm{mg}, 0.01 \mathrm{mmol}, 0.10$ equiv) and $p$-benzoquinone $(1 \mathrm{mg}, 0.01 \mathrm{mmol}, 0.10$ equiv) were dissolved in degassed $\mathrm{CH}_{2} \mathrm{Cl}_{2}(7 \mathrm{~mL}, 0.02 \mathrm{M})$ and the reaction mixture was heated at 40 ${ }^{\circ} \mathrm{C}$ for $12 \mathrm{~h}$. After this time, the solvent was removed under reduced pressure and the resulting crude product was purified by flash column chromatography (silica gel, 20\% EtOAc in hexanes $\rightarrow 2 \% \mathrm{MeOH}$ in $\mathrm{CH}_{2} \mathrm{Cl}_{2}$ ) to obtain macrocycle 26 (31 mg, 75\%) as a white solid: $\mathrm{R}_{f}$ $=0.56$ (silica gel, $10 \% \mathrm{MeOH}$ in $\left.\mathrm{CH}_{2} \mathrm{Cl}_{2}\right) ;[\alpha]^{25} \mathrm{D}=-6.11(c 0.08, \mathrm{MeOH}) ; \mathrm{mp}=188-189{ }^{\circ} \mathrm{C}$; ${ }^{1} \mathrm{H}$ NMR (400 MHz, DMSO- $\left.d_{6}\right) \delta(\mathrm{ppm}) 8.50(\mathrm{bs}, 1 \mathrm{H}), 8.45(\mathrm{~d}, J=7.3 \mathrm{~Hz}, 1 \mathrm{H}), 8.37(\mathrm{t}, J=$ $5.9 \mathrm{~Hz}, 1 \mathrm{H}), 7.46(\mathrm{dd}, J=7.8,0.9 \mathrm{~Hz}, 1 \mathrm{H}), 7.23-7.09$ (m, $3 \mathrm{H}), 5.44(\mathrm{dt}, J=15.9,5.4 \mathrm{~Hz}, 1$ 
H), $5.08(\mathrm{dt}, J=15.9,6.4 \mathrm{~Hz}, 1 \mathrm{H}), 4.35(\mathrm{p}, J=7.1 \mathrm{~Hz}, 1 \mathrm{H}), 3.85(\mathrm{dd}, J=14.7,6.4 \mathrm{~Hz}, 1 \mathrm{H})$, $3.44(\mathrm{dd}, J=14.7,5.7 \mathrm{~Hz}, 1 \mathrm{H}), 3.26(\mathrm{dd}, J=15.8,3.6 \mathrm{~Hz}, 1 \mathrm{H}), 3.08(\mathrm{dd}, J=15.5,5.1 \mathrm{~Hz}, 1$ H), $2.28-2.08(\mathrm{~m}, 4 \mathrm{H}), 1.31(\mathrm{~d}, J=7.2 \mathrm{~Hz}, 3 \mathrm{H}) ;{ }^{13} \mathrm{C}$ NMR (100 MHz, DMSO- $\left.d_{6}\right) \delta(\mathrm{ppm})$ $173.1,171.3,170.8,136.5,134.4,130.9,130.3,128.5,127.1,126.0,125.9,49.7,43.7,34.8$, 31.1, 27.9, 17.1; HRMS (H-ESI) $m / z:[\mathrm{M}+\mathrm{H}]^{+}$calcd for $\mathrm{C}_{17} \mathrm{H}_{22} \mathrm{~N}_{3} \mathrm{O}_{3}$ 316.1661; found 316.1655 .

Macrocycle 27. Diolefin 25 (135 mg, $0.30 \mathrm{mmol}, 1.0$ equiv), Hoveyda-Grubbs $2^{\text {nd }}$ generation catalyst (20 mg, $0.03 \mathrm{mmol}, 0.10$ equiv) and $p$-benzoquinone ( $4.0 \mathrm{mg}, 0.03 \mathrm{mmol}, 0.10$ equiv) were dissolved in degassed $\mathrm{CH}_{2} \mathrm{Cl}_{2}(16 \mathrm{~mL}, 0.02 \mathrm{M})$ and the reaction mixture was heated at 40 ${ }^{\circ} \mathrm{C}$ for $12 \mathrm{~h}$. After this time, the solvent was removed under reduced pressure and the resulting crude product was purified by flash column chromatography (silica gel, 30\% EtOAc in hexanes $\rightarrow 3 \% \mathrm{MeOH}$ in $\mathrm{CH}_{2} \mathrm{Cl}_{2}$ ) to obtain macrocycle 27 (100 mg, 79\%) as a white solid: $\mathrm{R}_{f}$ $=0.5$ (silica gel, $10 \% \mathrm{MeOH}$ in $\left.\mathrm{CH}_{2} \mathrm{Cl}_{2}\right) ;[\alpha]^{25} \mathrm{D}=-4.97(c 0.07, \mathrm{MeOH}) ; \mathrm{mp}=198-199{ }^{\circ} \mathrm{C}$; ${ }^{1} \mathrm{H}$ NMR (400 MHz, DMSO- $\left.d_{6}\right) \delta(\mathrm{ppm}) 8.54(\mathrm{bs}, 1 \mathrm{H}), 8.52(\mathrm{~d}, J=7.3 \mathrm{~Hz}, 1 \mathrm{H}), 8.37(\mathrm{t}, J=$ $6.0 \mathrm{~Hz}, 1 \mathrm{H}), 7.46-7.31(\mathrm{~m}, 5 \mathrm{H}), 7.29(\mathrm{~d}, J=2.6 \mathrm{~Hz}, 1 \mathrm{H}), 7.06(\mathrm{~d}, J=8.4 \mathrm{~Hz}, 1 \mathrm{H}), 6.77$ $(\mathrm{dd}, J=8.4,2.7 \mathrm{~Hz}, 1 \mathrm{H}), 5.41(\mathrm{dt}, J=15.9,5.4 \mathrm{~Hz}, 1 \mathrm{H}), 5.13-5.05(\mathrm{~m}, 1 \mathrm{H}), 5.04(\mathrm{~s}, 2 \mathrm{H})$, $4.36(\mathrm{p}, J=7.1 \mathrm{~Hz}, 1 \mathrm{H}), 3.86(\mathrm{dd}, J=14.8,6.5 \mathrm{~Hz}, 1 \mathrm{H}), 3.43(\mathrm{dd}, J=14.7,5.6 \mathrm{~Hz}, 1 \mathrm{H})$, $3.20(\mathrm{dd}, J=16.4,3.9 \mathrm{~Hz}, 1 \mathrm{H}), 3.03(\mathrm{dd}, J=16.2,5.0 \mathrm{~Hz}, 1 \mathrm{H}), 2.28-2.03(\mathrm{~m}, 4 \mathrm{H}), 1.30$ $(\mathrm{d}, J=7.2 \mathrm{~Hz}, 3 \mathrm{H}) ;{ }^{13} \mathrm{C} \mathrm{NMR}\left(100 \mathrm{MHz}, \mathrm{DMSO}-d_{6}\right) \delta(\mathrm{ppm}) 173.1,171.2,171.0,157.4$, $137.6,137.3,131.5,130.7,128.8,128.2,128.1,128.1,128.0,125.8,111.8,69.7,49.7,43.4$, 34.7, 33.7, 27.9, 16.8; HRMS (H-ESI) $m / z:[\mathrm{M}+\mathrm{H}]^{+}$calcd for $\mathrm{C}_{24} \mathrm{H}_{28} \mathrm{~N}_{3} \mathrm{O}_{4} 422.2080$; found 422.2074 . 
Diolefin 8. Dipeptide 11 (328 mg, $0.70 \mathrm{mmol}, 1.0$ equiv) in $\mathrm{CH}_{2} \mathrm{Cl}_{2}(20 \mathrm{~mL})$ was treated with TFA (3.5 mL) in exactly the same manner as previously described for synthesis of $\mathbf{2 4}$. A solution of the ammonium salt and acid $\mathbf{1 4}^{10}$ (171 $\mathrm{mg}, 0.70 \mathrm{mmol}, 1.0$ equiv), in $\mathrm{CH}_{2} \mathrm{Cl}_{2}$ (15 $\mathrm{mL}$ ) was treated with HATU (400 mg, $1.05 \mathrm{mmol}, 1.0$ equiv) and DIPEA (0.35 mL, 2.10 mmol, 3.0 equiv) and the resulting solution was stirred at $25{ }^{\circ} \mathrm{C}$ for $12 \mathrm{~h}$. After this time, a saturated aqueous $\mathrm{NH}_{4} \mathrm{Cl}$ solution was added and the organic layer was separated. The aqueous phase was extracted with EtOAc, and the combined organic layers were washed with brine, dried over anhydrous $\mathrm{MgSO}_{4}$, filtered and the solvent evaporated under reduced pressure. The crude product was purified by flash column chromatography (silica gel, 20\% EtOAc in hexanes) to obtain diolefin 8 (250 mg, $74 \%$ over two steps) as a white solid: $\mathrm{R}_{f}=$ 0.73 (silica gel, $100 \%$ EtOAc); $[\alpha]^{25} \mathrm{D}=-6.06\left(c 0.05, \mathrm{CH}_{2} \mathrm{Cl}_{2}\right) ; \mathrm{mp}=98-99{ }^{\circ} \mathrm{C} ;{ }^{1} \mathrm{H} \mathrm{NMR}$ $\left(400 \mathrm{MHz}, \mathrm{CDCl}_{3}\right) \delta(\mathrm{ppm}) 8.12(\mathrm{bs}, 1 \mathrm{H}), 7.68(\mathrm{~d}, J=7.3 \mathrm{~Hz}, 1 \mathrm{H}), 7.54(\mathrm{~d}, J=2.6 \mathrm{~Hz}, 1 \mathrm{H})$, $7.44-7.27(\mathrm{~m}, 5 \mathrm{H}), 7.06(\mathrm{~m}, 1 \mathrm{H}), 6.78-6.71(\mathrm{~m}, 1 \mathrm{H}), 6.70-6.63(\mathrm{~m}, 1 \mathrm{H}), 5.92(\mathrm{ddt}, J=$ 16.5, 10.2, $6.1 \mathrm{~Hz}, 1 \mathrm{H}), 5.79(\mathrm{ddd}, J=17.3,10.3,7.2 \mathrm{~Hz}, 1 \mathrm{H}), 5.27(\mathrm{~m}, 1 \mathrm{H}), 5.10(\mathrm{~m}, 1 \mathrm{H})$, $5.01(\mathrm{~s}, 2 \mathrm{H}), 4.60-4.51(\mathrm{~m}, 1 \mathrm{H}), 4.33(\mathrm{dd}, J=17.1,7.4 \mathrm{~Hz}, 1 \mathrm{H}), 4.15-4.04(\mathrm{~m}, 2 \mathrm{H}), 3.62$ $(\mathrm{dd}, J=17.1,4.6 \mathrm{~Hz}, 1 \mathrm{H}), 3.36-3.22(\mathrm{~m}, 1 \mathrm{H}), 2.32(\mathrm{dq}, J=13.7,6.8 \mathrm{~Hz}, 1 \mathrm{H}), 1.42(\mathrm{~d}, J=$ $7.0 \mathrm{~Hz}, 3 \mathrm{H}), 1.10(\mathrm{~d}, J=6.9 \mathrm{~Hz}, 3 \mathrm{H}), 0.94(\mathrm{~s}, 9 \mathrm{H}), 0.19(\mathrm{~s}, 3 \mathrm{H}), 0.17(\mathrm{~s}, 3 \mathrm{H}) ;{ }^{13} \mathrm{C} \mathrm{NMR}$ $\left(100 \mathrm{MHz}, \mathrm{CDCl}_{3}\right) \delta(\mathrm{ppm}) 175.5,170.8,169.8,157.8,138.2,136.8,136.3,136.1,130.9$, $128.5,127.9,127.5,122.7,117.9,116.3,112.2,109.9,70.1,49.8,46.6,43.1,38.9,38.5,25.2$, 18.1, 17.4, 16.2, 13.6, 2.9, -4.5, -4.7; HRMS (H-ESI) $m / z:[\mathrm{M}+\mathrm{H}]^{+}$calcd for $\mathrm{C}_{33} \mathrm{H}_{48} \mathrm{~N}_{3} \mathrm{O}_{5} \mathrm{Si}$ 594.3363; found 594.3365.

Diolefin 7. To a solution of diolefin 8 (90 $\mathrm{mg}, 0.15 \mathrm{mmol}, 1.0$ equiv) in THF (10 mL) was added $\mathrm{HF} \bullet p y r(0.6 \mathrm{~mL})$ at $0{ }^{\circ} \mathrm{C}$ and the mixture was stirred for $12 \mathrm{~h}$. The reaction mixture was 
quenched with a saturated aqueous $\mathrm{NaHCO}_{3}$ solution and diluted with EtOAc. The organic layer was separated and the aqueous phase was extracted with EtOAc. The combined organic layers were washed with brine, dried over anhydrous $\mathrm{MgSO}_{4}$, filtered and the solvent evaporated under reduced pressure. The residue was purified by flash column chromatography (silica gel, $2 \% \mathrm{MeOH}$ in $\mathrm{CH}_{2} \mathrm{Cl}_{2}$ ) to obtain diolefin 7 (60 mg, 83\%) as a white solid: $\mathrm{R}_{f}=0.66$ (silica gel, $10 \% \mathrm{MeOH}$ in $\left.\mathrm{CH}_{2} \mathrm{Cl}_{2}\right) ;[\alpha]^{25} \mathrm{D}=-4.91\left(c 0.08, \mathrm{CH}_{2} \mathrm{Cl}_{2}\right) ; \mathrm{mp}=90-91{ }^{\circ} \mathrm{C} ;{ }^{1} \mathrm{H} \mathrm{NMR}$ $\left(400 \mathrm{MHz}, \mathrm{CDCl}_{3}\right) \delta(\mathrm{ppm}) 8.16(\mathrm{bs}, 1 \mathrm{H}), 7.69(\mathrm{~d}, J=7.1 \mathrm{~Hz}, 1 \mathrm{H}), 7.56(\mathrm{~d}, J=2.6 \mathrm{~Hz}, 1 \mathrm{H})$, $7.43-7.28(\mathrm{~m}, 5 \mathrm{H}), 7.05(\mathrm{~d}, J=8.4 \mathrm{~Hz}, 1 \mathrm{H}), 6.88-6.81(\mathrm{~m}, 1 \mathrm{H}), 6.73(\mathrm{dd}, J=8.4,2.6 \mathrm{~Hz}$, $1 \mathrm{H}), 5.93(\mathrm{ddd}, J=16.3,11.1,6.0 \mathrm{~Hz}, 1 \mathrm{H}), 5.80(\mathrm{ddd}, J=17.3,10.3,7.2 \mathrm{~Hz}, 1 \mathrm{H}), 5.28$ (dd, $J=16.0,2.2 \mathrm{~Hz}, 1 \mathrm{H}), 5.20(\mathrm{~d}, J=10.3 \mathrm{~Hz}, 1 \mathrm{H}) ; 5.14-5.04(\mathrm{~m}, 2 \mathrm{H}), 5.01(\mathrm{~s}, 2 \mathrm{H}), 4.59-$ $4.48(\mathrm{~m}, 1 \mathrm{H}), 4.31(\mathrm{dd}, J=17.2,7.5 \mathrm{~Hz}, 1 \mathrm{H}), 3.62(\mathrm{dd}, J=17.1,4.8 \mathrm{~Hz}, 1 \mathrm{H}), 3.33-3.26$ (m, $2 \mathrm{H}), 2.35(\mathrm{dq}, J=13.6,6.8 \mathrm{~Hz}, 1 \mathrm{H}), 1.41(\mathrm{~d}, J=7.1 \mathrm{~Hz}, 3 \mathrm{H}), 1.09(\mathrm{~d}, J=6.8 \mathrm{~Hz}, 3 \mathrm{H})$; ${ }^{13} \mathrm{C}$ NMR (100 MHz, $\left.\mathrm{CDCl}_{3}\right) \delta(\mathrm{ppm}) 175.5,170.7,169.9,157.8,138.4,136.9,136.3,136.2$, $130.8,128.5,127.9,127.5,122.8,117.7,116.3,111.9,109.9,70.1,49.8,43.2,36.4,23.8$, 19.6, 17.3, 13.5; HRMS (H-ESI) $m / z$ : $[\mathrm{M}+\mathrm{H}]^{+}$calcd for $\mathrm{C}_{27} \mathrm{H}_{34} \mathrm{~N}_{3} \mathrm{O}_{5}$ 480.2498; found 480.2502 .

Macrocycle 28. Diolefin 7 (30 mg, $0.06 \mathrm{mmol}, 1.0$ equiv), Hoveyda-Grubbs $2^{\text {nd }}$ generation catalyst $(4.0 \mathrm{mg}, 0.01 \mathrm{mmol}, 0.10$ equiv) and $p$-benzoquinone $(1.0 \mathrm{mg}, 0.01 \mathrm{mmol}, 0.10$ equiv) were dissolved in degassed $\mathrm{CH}_{2} \mathrm{Cl}_{2}(3 \mathrm{~mL}, 0.02 \mathrm{M})$ and the reaction mixture was heated at $40{ }^{\circ} \mathrm{C}$ for $12 \mathrm{~h}$. After this time, the solvent was removed under reduced pressure and the resulting crude product was purified by flash column chromatography (silica gel, $\mathrm{CH}_{2} \mathrm{Cl}_{2}$ $\rightarrow 5 \% \mathrm{MeOH}$ in $\left.\mathrm{CH}_{2} \mathrm{Cl}_{2}\right)$ to obtain $28(20 \mathrm{mg}, 71 \%)$ as a white solid: $\mathrm{R}_{f}=0.44$ (silica gel, $10 \% \mathrm{MeOH}$ in $\left.\mathrm{CH}_{2} \mathrm{Cl}_{2}\right) ;[\alpha]^{25} \mathrm{D}=-8.4(c 0.05, \mathrm{MeOH}) ; \mathrm{mp}=203-204{ }^{\circ} \mathrm{C} ;{ }^{1} \mathrm{H} \mathrm{NMR}(400$ 
MHz, DMSO-d6) $\delta(\mathrm{ppm}) 8.67(\mathrm{bs}, 1 \mathrm{H}), 8.49(\mathrm{t}, J=5.5 \mathrm{~Hz}, 1 \mathrm{H}), 7.46-7.29(\mathrm{~m}, 6 \mathrm{H}), 7.07$ $(\mathrm{d}, J=2.7 \mathrm{~Hz}, 1 \mathrm{H}), 6.82(\mathrm{dd}, J=8.3,2.7 \mathrm{~Hz}, 1 \mathrm{H}), 5.62(\mathrm{dt}, J=15.9,5.11 \mathrm{~Hz}, 1 \mathrm{H}), 5.05(\mathrm{~s}$, $2 \mathrm{H}), 4.98(\mathrm{dd}, J=15.9,7.0 \mathrm{~Hz}, 1 \mathrm{H}), 4.32-4.23(\mathrm{~m}, 1 \mathrm{H}), 4.13(\mathrm{dd}, J=6.6,4.7 \mathrm{~Hz}, 1 \mathrm{H})$, $3.85(\mathrm{dd}, J=14.3,5.8 \mathrm{~Hz}, 1 \mathrm{H}), 3.19-2.99(\mathrm{~m}, 3 \mathrm{H}), 2.68-2.64(\mathrm{~m}, 1 \mathrm{H}), 1.30(\mathrm{~d}, J=7.3$ $\mathrm{Hz}, 3 \mathrm{H}), 0.85(\mathrm{~d}, J=6.9 \mathrm{~Hz}, 3 \mathrm{H}) ;{ }^{13} \mathrm{C} \mathrm{NMR}\left(100 \mathrm{MHz}, \mathrm{DMSO}-d_{6}\right) \delta(\mathrm{ppm}) 174.9,171.5$, $170.6,157.5,137.6,137.5,131.6,131.0,130.2,128.8,128.2,128.1,127.6,113.3,112.3,72.7$ 69.7, 49.6, 44.9, 43.6, 33.8, 16.9, 11.0; HRMS (H-ESI) $m / z:[\mathrm{M}+\mathrm{H}]^{+}$calcd for $\mathrm{C}_{25} \mathrm{H}_{30} \mathrm{~N}_{3} \mathrm{O}_{5}$ 452.2186; found 452.2188 .

Aniline 30. To a solution of allylic alcohol $\mathbf{2 9}^{17}$ (1.9 g, $10.60 \mathrm{mmol}, 1.0$ equiv) in EtOH (60 $\mathrm{mL})$ was added a solution of $\mathrm{NH}_{4} \mathrm{Cl}(2.8 \mathrm{~g}, 53.02 \mathrm{mmol}, 5.0$ equiv $)$ in water $(40 \mathrm{~mL})$ followed by $\mathrm{Zn}$ dust ( $10 \mathrm{~g}, 159.06 \mathrm{mmol}, 15.0$ equiv) in ten portions of $1 \mathrm{~g}$ each over $30 \mathrm{~min}$ at $25^{\circ} \mathrm{C}$. The mixture was stirred at this temperature for $12 \mathrm{~h}$ and then the reaction mixture was diluted with $\mathrm{CH}_{2} \mathrm{Cl}_{2}$ and water, then filtered and rinsed with $\mathrm{CH}_{2} \mathrm{Cl}_{2}$. The filtrate was diluted with water and extracted with $\mathrm{CH}_{2} \mathrm{Cl}_{2}$, and the organic phase washed with brine, dried over anhydrous $\mathrm{MgSO}_{4}$, filtered and the solvent evaporated under reduced pressure. The resulting residue was purified by flash column chromatography (silica gel, 10\% EtOAc in hexanes) to obtain aniline $30(1.4 \mathrm{~g}, 85 \%)$ as a yellow oil: $\mathrm{R}_{f}=0.48$ (silica gel, $40 \%$ EtOAc in hexanes); ${ }^{1} \mathrm{H}$ NMR $\left(400 \mathrm{MHz}, \mathrm{CDCl}_{3}\right) \delta(\mathrm{ppm}) 7.13-7.06(\mathrm{~m}, 2 \mathrm{H}), 6.75(\mathrm{td}, J=7.5,1.2 \mathrm{~Hz}, 1 \mathrm{H})$, $6.65(\mathrm{dd}, J=7.9,0.9 \mathrm{~Hz}, 1 \mathrm{H}), 6.15(\mathrm{ddd}, J=17.0,10.4,5.3 \mathrm{~Hz}, 1 \mathrm{H}), 5.34(\mathrm{dt}, J=17.2,1.4$ $\mathrm{Hz}, 1 \mathrm{H}), 5.25(\mathrm{dt}, J=10.4,1.5 \mathrm{~Hz}, 1 \mathrm{H}), 5.15(\mathrm{~d}, J=5.2 \mathrm{~Hz}, 1 \mathrm{H}), 3.75(\mathrm{bs}, 2 \mathrm{H}) ;{ }^{13} \mathrm{C} \mathrm{NMR}$ $\left(100 \mathrm{MHz}, \mathrm{CDCl}_{3}\right) \delta(\mathrm{ppm}) 144.8,138.3,128.9,128.0,126.4,118.6,117.1,115.4,74.2 ;$ HRMS (H-ESI) m/z: $[\mathrm{M}+\mathrm{H}]^{+}$calcd for $\mathrm{C}_{9} \mathrm{H}_{12} \mathrm{NO} 150.0919$; found 150.0907 . 
Dipeptide 31. To a solution of aniline 30 (1.3 g, $8.71 \mathrm{mmol}, 1.0$ equiv) and Boc-Gly-D-Ala$\mathrm{OH}(21)\left(2.1 \mathrm{~g}, 8.71 \mathrm{mmol}, 1.0\right.$ equiv) in $\mathrm{CH}_{2} \mathrm{Cl}_{2}(15 \mathrm{~mL})$ was added HATU (3.6 g, 13.07 mmol, 1.5 equiv) and DIPEA ( $1.5 \mathrm{~mL}, 8.71 \mathrm{mmol}, 1.0$ equiv) and the mixture was stirred for $12 \mathrm{~h}$ at $25^{\circ} \mathrm{C}$. After this time, a saturated aqueous $\mathrm{NH}_{4} \mathrm{Cl}$ solution was added and the organic layer was separated. The aqueous phase was extracted with EtOAc, and the combined organic layers were washed with brine, dried over anhydrous $\mathrm{MgSO}_{4}$, filtered and the solvent evaporated under reduced pressure. The crude product was purified by flash column chromatography (silica gel, 20\% EtOAc in hexanes $\rightarrow 40 \%$ EtOAc in hexanes) to obtain dipeptide 31 ( $2.5 \mathrm{~g}, 76 \%, 1: 1$ mixture of diastereoisomers) as a white foam. Data assigned for the mixture of diastereoisomers: $\mathrm{R}_{f}=0.56$ (silica gel, 100\% EtOAc); ${ }^{1} \mathrm{H}$ NMR (400 MHz, $\left.\mathrm{CDCl}_{3}\right) \delta(\mathrm{ppm}) 9.75(\mathrm{~d}, J=8.6 \mathrm{~Hz}, 1 \mathrm{H}), 7.96(\mathrm{t}, J=8.2 \mathrm{~Hz}, 1 \mathrm{H}), 7.39-7.28(\mathrm{~m}, 1 \mathrm{H}), 7.25$ $-7.15(\mathrm{~m}, 1 \mathrm{H}), 7.10(\mathrm{~m}, 1 \mathrm{H}), 7.06-6.98(\mathrm{~m}, 1 \mathrm{H}), 6.08-5.92(\mathrm{~m}, 1 \mathrm{H}), 5.85-5.64(\mathrm{~m}, 1$ H), $5.20(\mathrm{~d}, J=5.7 \mathrm{~Hz}, 1 \mathrm{H}), 5.16-5.07(\mathrm{~m}, 1 \mathrm{H}), 4.54-4.35(\mathrm{~m}, 1 \mathrm{H}), 3.89-3.62(\mathrm{~m}, 2 \mathrm{H})$, 1.37 (s, $9 \mathrm{H}), 1.33(\mathrm{~d}, J=7.2 \mathrm{~Hz}, 3 \mathrm{H}) ;{ }^{13} \mathrm{C} \mathrm{NMR}\left(100 \mathrm{MHz}, \mathrm{CDCl}_{3}\right) \delta(\mathrm{ppm}) 170.5,170.4$, $170.4,170.1,170.1,138.1,138.1,136.3,128.6,128.5,128.1,127.9,124.4,122.4,122.3$, 116.0, 115.9, 80.9, 60.4, 50.3, 50.1, 44.1, 44.0, 28.3, 28.3, 17.8, 17.8; HRMS (H-ESI) m/z: [M $+\mathrm{H}]^{+}$calcd for $\mathrm{C}_{19} \mathrm{H}_{28} \mathrm{~N}_{3} \mathrm{O}_{5} 378.2029$; found 378.2034.

Trifluoroacetate Derivative 33. Dipeptide 31 (1.0 g, $2.65 \mathrm{mmol}, 1.0$ equiv) in $\mathrm{CH}_{2} \mathrm{Cl}_{2}$ (20 $\mathrm{mL})$ was treated with TFA $(13 \mathrm{~mL})$ in exactly the same manner as previously described for synthesis of 24. A solution of the ammonium salt and Kosher acid 23 ( $0.27 \mathrm{~mL}, 2.65 \mathrm{mmol}$, 1.0 equiv), in $\mathrm{CH}_{2} \mathrm{Cl}_{2}(35 \mathrm{~mL})$ was treated with HATU (1.0 g, $2.65 \mathrm{mmol}, 1.0$ equiv) and DIPEA (1.4 mL, $7.95 \mathrm{mmol}, 3.0$ equiv) and the resulting solution was stirred at $25^{\circ} \mathrm{C}$ for 12 h. After this time, a saturated aqueous $\mathrm{NH}_{4} \mathrm{Cl}$ solution was added and the organic layer was 
separated. The aqueous phase was extracted with EtOAc, and the combined organic layers were washed with brine, dried over anhydrous $\mathrm{MgSO}_{4}$, filtered and the solvent evaporated under reduced pressure. The resulting residue was purified by flash column chromatography (silica gel, 30\% EtOAc in hexanes) to obtain trifluoroacetate derivative $\mathbf{3 3}$ (784 $\mathrm{mg}, 65 \%$ ) as a white solid: $\mathrm{R}_{f}=0.18$ (silica gel, $100 \%$ EtOAc); $[\alpha]^{25} \mathrm{D}=-9.14\left(c 0.12, \mathrm{CH}_{2} \mathrm{Cl}_{2}\right) ; \mathrm{mp}=109$ $110{ }^{\circ} \mathrm{C} ;{ }^{1} \mathrm{H}$ NMR $\left(400 \mathrm{MHz}, \mathrm{CDCl}_{3}\right) \delta(\mathrm{ppm}) 8.62$ (bs, $\left.1 \mathrm{H}\right), 7.55-7.35$ (m, $\left.2 \mathrm{H}\right), 7.25-7.20$ $(\mathrm{m}, 1 \mathrm{H}), 7.18-7.12(\mathrm{~m}, 1 \mathrm{H}), 6.85(\mathrm{~d}, J=15.4 \mathrm{~Hz}, 1 \mathrm{H}), 6.15(\mathrm{dt}, J=15.4,6.6 \mathrm{~Hz}, 1 \mathrm{H})$, $5.77-5.66(\mathrm{~m}, 1 \mathrm{H}), 5.01-4.90(\mathrm{~m}, 4 \mathrm{H}), 4.69-4.58(\mathrm{~m}, 1 \mathrm{H}), 4.01-3.90(\mathrm{~m}, 2 \mathrm{H}), 2.37$ $2.22(\mathrm{~m}, 4 \mathrm{H}), 1.42(\mathrm{~d}, J=5.4 \mathrm{~Hz}, 3 \mathrm{H}) ;{ }^{13} \mathrm{C} \mathrm{NMR}\left(100 \mathrm{MHz}, \mathrm{CDCl}_{3}\right) \delta(\mathrm{ppm})$ 173.8, 171.2, $169.9,157.7,136.7,134.3,132.0,129.7,129.1,126.7,126.3,125.1,123.1,115.7,113.1,68.5$, 49.8, 43.3, 35.1, 29.3, 17.4; HRMS (H-ESI) $m / z:[\mathrm{M}+\mathrm{H}]^{+}$calcd for $\mathrm{C}_{21} \mathrm{H}_{25} \mathrm{~F}_{3} \mathrm{~N}_{3} \mathrm{O}_{5}$ 456.1746; found 456.1752 .

Acid 36. A $5 \mathrm{~mL}$ polypropylene syringe fitted with polyethylene porous disk charged with 2chlorotrityl chloride (CTC) resin (300 mg, L=1.3 mmol/g, $0.39 \mathrm{mmol}, 1.0$ equiv), was loaded with a solution of Fmoc-D-Ala-OH (34) (364 mg, 1.17 mmol, 3.0 equiv) and DIPEA (0.23 $\mathrm{mL}, 1.36 \mathrm{mmol}, 3.5$ equiv) in dry DMF ( $3 \mathrm{~mL})$. The resulting suspension was shaken at 280 rpm for $30 \mathrm{~h}$, then the solution was unloaded and the resin was washed by shaking with dry DMF $(5 \times 3 \mathrm{~mL})$. The resulting yellow resin was used in the next step.

The polypropylene syringe loaded with the yellow resin was treated with a solution of $20 \%$ piperidine in DMF (3 x $3 \mathrm{~mL} \times 10 \mathrm{~min}$ at $280 \mathrm{rpm})$. After the last run, the resin was washed with dry DMF (5 x $3 \mathrm{~mL}$ ) and loaded with a solution of Fmoc-Gly-OH (35) (232 mg, 0.78 mmol, 2.0 equiv), HOBt (105 mg, $0.78 \mathrm{mmol}, 2.0$ equiv) and DIC (0.15 mL, $0.97 \mathrm{mmol}, 2.5$ equiv) in dry DMF (3 mL). The resulting suspension was shaken at $280 \mathrm{rpm}$ for $24 \mathrm{~h}$, and then 
the solution was unloaded and the resin washed with dry DMF (5 x $3 \mathrm{~mL})$. The resulting yellow resin was used in the next step.

To a $5 \mathrm{~mL}$ polypropylene syringe fitted with polyethylene porus disk and loaded with the resulting Fmoc protected dipeptide was added a solution of $20 \%$ piperidine in DMF $(3 \times 3 \mathrm{~mL}$ x $10 \mathrm{~min}$ at $280 \mathrm{rpm})$. After the last run, the resin was washed with dry DMF (5 x $3 \mathrm{~mL})$ and treated with a solution of Kosher acid $23(80 \mu \mathrm{L}, 0.78 \mathrm{mmol}, 2.0$ equiv) HOBt (105 mg, 0.78 mmol, 2.0 equiv) and DIC ( $0.2 \mathrm{~mL}, 0.97 \mathrm{mmol}, 2.5$ equiv) in dry DMF ( $3 \mathrm{~mL})$. The resulting suspension was shaken at $280 \mathrm{rpm}$ for $24 \mathrm{~h}$, and then the solution was unloaded and the resinwashed with dry DMF ( 5 x $3 \mathrm{~mL})$. The resulting yellow resin was treated with a solution of $\mathrm{CH}_{2} \mathrm{Cl}_{2} / \mathrm{AcOH} / \mathrm{TFE}$ (7:2:1, $3 \mathrm{~mL}$ ) for $30 \mathrm{~min}$. After that, the solution was collected and the resin washed with $\mathrm{CH}_{2} \mathrm{Cl}_{2}(2 \times 3 \mathrm{~mL})$. All the collected organic solvents were evaporated under reduced pressure and the resulting acid $\mathbf{3 6}$ (71 $\mathrm{mg}, 81 \%$ overall yield from CTC resin) was obtained as a white solid which not required further purification: $\mathrm{R}_{f}=0.21$ (silica gel, $100 \%$ EtOAc); $[\alpha]^{25} \mathrm{D}=-5.21\left(c 0.07, \mathrm{CH}_{2} \mathrm{Cl}_{2}\right) ; \mathrm{mp}=89-90{ }^{\circ} \mathrm{C} ;{ }^{1} \mathrm{H}$ NMR $\left(400 \mathrm{MHz}, \mathrm{CDCl}_{3}\right)$ $\delta(\mathrm{ppm}) 6.91(\mathrm{bs}, 1 \mathrm{H}), 6.62(\mathrm{bs}, 1 \mathrm{H}), 5.84(\mathrm{ddd}, J=16.2,11.1,5.9 \mathrm{~Hz}, 1 \mathrm{H}), 5.10(\mathrm{dd}, J=$ 17.1, $1.5 \mathrm{~Hz}, 1 \mathrm{H}), 5.04(\mathrm{dd}, J=10.3,1.0 \mathrm{~Hz}, 1 \mathrm{H}), 4.63-4.53(\mathrm{~m}, 1 \mathrm{H}), 4.10(\mathrm{dd}, J=16.4$, $5.5 \mathrm{~Hz}, 1 \mathrm{H}), 3.94(\mathrm{dd}, J=17.0,4.9 \mathrm{~Hz}, 1 \mathrm{H}), 2.46-2.35(\mathrm{~m}, 4 \mathrm{H}), 1.48(\mathrm{~d}, J=6.9 \mathrm{~Hz}, 3 \mathrm{H})$; ${ }^{13} \mathrm{C}$ NMR $\left(100 \mathrm{MHz}, \mathrm{CDCl}_{3}\right) \delta(\mathrm{ppm}) 175.4,175.3,162.9,136.7,115.8,42.5,36.7,31.6$, 29.4, 23.3; HRMS (H-ESI) $m / z:[\mathrm{M}+\mathrm{H}]^{+}$calcd for $\mathrm{C}_{10} \mathrm{H}_{17} \mathrm{~N}_{2} \mathrm{O}_{4} 229.1188$; found 229.1194 .

Diolefin 32. A solution of the aniline $30(31 \mathrm{mg}, 0.20 \mathrm{mmol}, 1.0$ equiv) and acid 36 (46 mg, $0.20 \mathrm{mmol}, 1.0$ equiv) in dry DMF (8 mL) was treated with HATU (76 mg, $0.20 \mathrm{mmol}, 1.0$ equiv) and DIPEA (40 $\mu \mathrm{L}, 0.20 \mathrm{mmol}, 1.0$ equiv) and the resulting solution was stirred at 25 ${ }^{\circ} \mathrm{C}$ for $12 \mathrm{~h}$. After this time, a saturated aqueous $\mathrm{NH}_{4} \mathrm{Cl}$ solution was added and the organic 
layer was separated. The aqueous phase was extracted with EtOAc, and the combined organic layers were washed with brine, dried over anhydrous $\mathrm{MgSO}_{4}$, filtered and the solvent evaporated under reduced pressure. The crude product was purified by flash column chromatography (silica gel, 20\% EtOAc in hexanes $\rightarrow 80 \%$ EtOAc in hexanes) to obtain diolefin 32 (55 mg, 77\%, 1:1 mixture of diastereoisomers) as a white foam. Data assigned for the mixture of diastereoisomers: $\mathrm{R}_{f}=0.37$ (silica gel, 100\% EtOAc); ${ }^{1} \mathrm{H}$ NMR (400 MHz, $\left.\mathrm{CDCl}_{3}\right) \delta(\mathrm{ppm}) 9.83(\mathrm{bs}, 1 \mathrm{H}), 9.66(\mathrm{bs}, 1 \mathrm{H}), 8.16(\mathrm{~d}, J=8.1 \mathrm{~Hz}, 1 \mathrm{H}), 8.11(\mathrm{~d}, J=8.1 \mathrm{~Hz}, 1$ H), $7.32-7.23(\mathrm{~m}, 4 \mathrm{H}), 7.16-7.10(\mathrm{~m}, 2 \mathrm{H}), 7.06(\mathrm{td}, J=7.5,0.7 \mathrm{~Hz}, 2 \mathrm{H}), 6.80-6.66(\mathrm{~m}$, $2 \mathrm{H}), 6.14-5.99(\mathrm{~m}, 2 \mathrm{H}), 5.82(\mathrm{dd}, J=11.6,5.2 \mathrm{~Hz}, 1 \mathrm{H}), 5.76(\mathrm{dd}, J=10.3,6.2 \mathrm{~Hz}, 1 \mathrm{H})$, $5.35-5.25(\mathrm{~m}, 2 \mathrm{H}), 5.24-5.22(\mathrm{~m}, 2 \mathrm{H}), 5.20-5.12(\mathrm{~m}, 2 \mathrm{H}), 5.07(\mathrm{dd}, J=18.3,2.9 \mathrm{~Hz}, 2$ H), $5.04-4.99(\mathrm{~m}, 2 \mathrm{H}), 4.84(\mathrm{bs}, 2 \mathrm{H}), 4.56(\mathrm{dd}, J=14.7,7.4 \mathrm{~Hz}, 1 \mathrm{H}), 4.48(\mathrm{dd}, J=14.1$, $6.9 \mathrm{~Hz}, 1 \mathrm{H}), 4.14(\mathrm{dd}, J=6.6,2.7 \mathrm{~Hz}, 1 \mathrm{H}), 4.10(\mathrm{dd}, J=6.2,3.2 \mathrm{~Hz}, 1 \mathrm{H}), 3.82(\mathrm{~d}, J=4.8$ $\mathrm{Hz}, 1 \mathrm{H}), 3.79-3.75(\mathrm{~m}, 1 \mathrm{H}), 2.40-2.29(\mathrm{~m}, 8 \mathrm{H}), 1.46(\mathrm{~d}, J=7.8 \mathrm{~Hz}, 3 \mathrm{H}), 1.44(\mathrm{~d}, J=7.8$ $\mathrm{Hz}, 3 \mathrm{H}) ;{ }^{13} \mathrm{C} \mathrm{NMR}\left(100 \mathrm{MHz}, \mathrm{CDCl}_{3}\right) \delta(\mathrm{ppm}) 174.0,173.9,170.5,170.4,169.4,169.3$, $138.4,138.2,136.8,136.5,131.0,130.8,128.5,128.4,128.4,128.3,128.1,127.8,124.3$, $124.2,122.2,122.1,115.8,115.7,115.7,115.6,50.6,50.2,42.9,42.8,35.3,35.2,31.9,31.4$, 29.6, 29.3, 17.7, 17.6; HRMS (H-ESI) $\mathrm{m} / z$ : $[\mathrm{M}+\mathrm{H}]^{+}$calcd for $\mathrm{C}_{19} \mathrm{H}_{26} \mathrm{~N}_{3} \mathrm{O}_{4}$ 360.1923; found 360.1917.

Silyl Ether 37. To a solution of $32\left(45 \mathrm{mg}, 0.14 \mathrm{mmol}, 1.0\right.$ equiv) in $\mathrm{CH}_{2} \mathrm{Cl}_{2}(5 \mathrm{~mL})$ was added 2,6-lutidine ( $30 \mu \mathrm{L}, 0.25 \mathrm{mmol}, 2.0$ equiv) at $0{ }^{\circ} \mathrm{C}$ and the mixture was stirred $10 \mathrm{~min}$ at this temperature. After this time TBSOTf $\left(60 \mu \mathrm{L}, 0.25 \mathrm{mmol}, 2.0\right.$ equiv) was added at $0{ }^{\circ} \mathrm{C}$ and the mixture was stirred $12 \mathrm{~h}$ at $25^{\circ} \mathrm{C}$. Then, the reaction was quenched by addition of $\mathrm{H}_{2} \mathrm{O}$. After decantation of the organic layer, the aqueous phase was extracted with EtOAc, and 
the combined organic layers were washed with brine, dried over anhydrous $\mathrm{MgSO}_{4}$, filtered and the solvent evaporated under reduced pressure. The crude product was purified by flash column chromatography (silica gel, 20\% EtOAc in hexanes $\rightarrow 100 \%$ EtOAc) to obtain silyl ether 37 (50 mg, 85\%, 1:1 mixture of diastereoisomers) as a white solid. Data assigned for the mixture of diastereoisomers: $\mathrm{R}_{f}=0.80$ (silica gel, $100 \%$ EtOAc); $\mathrm{mp}=121-122{ }^{\circ} \mathrm{C} ;{ }^{1} \mathrm{H}$ NMR $\left(400 \mathrm{MHz}, \mathrm{CDCl}_{3}\right) \delta(\mathrm{ppm}) 8.16(\mathrm{dd}, J=8.1,7.9 \mathrm{~Hz}, 1 \mathrm{H}), 7.31-7.27(\mathrm{~m}, 1 \mathrm{H}), 7.12-7.03$ (m, $2 \mathrm{H}), 7.01-6.95(\mathrm{~m}, 1 \mathrm{H}), 6.42(\mathrm{~d}, J=5.2 \mathrm{~Hz}, 1 \mathrm{H}), 6.03-5.91(\mathrm{~m}, 1 \mathrm{H}), 5.88-5.76(\mathrm{~m}$, $1 \mathrm{H}), 5.33-5.10(\mathrm{~m}, 3 \mathrm{H}), 5.10-4.98(\mathrm{~m}, 2 \mathrm{H}), 4.47(\mathrm{p}, J=6.9 \mathrm{~Hz}, 1 \mathrm{H}), 4.02-3.96(\mathrm{~m}, 2$ H), $2.44-2.36(\mathrm{~m}, 2 \mathrm{H}), 2.37-2.31(\mathrm{~m}, 2 \mathrm{H}), 1.50-1.42(\mathrm{~m}, 3 \mathrm{H}), 0.91(\mathrm{~s}, 9 \mathrm{H}), 0.14$ (s, 3 $\mathrm{H}), 0.00(\mathrm{~s}, 3 \mathrm{H}) ;{ }^{13} \mathrm{C} \mathrm{NMR}\left(100 \mathrm{MHz}, \mathrm{CDCl}_{3}\right) \delta(\mathrm{ppm}) 172.7,169.7,169.7,168.3,168.2$, $138.9,138.7,136.9,136.4,136.3,130.5,130.2,128.7,128.6,127.9,127.9,124.4,124.3$, $122.3,122.3,115.7,114.5,114.4,50.1,49.9,42.9,38.6,35.5,29.4,25.7,19.1,19.1,18.3$, 18.3, -4.9, -5.0, -5.1, -5.1; HRMS (H-ESI) $m / z:[\mathrm{M}+\mathrm{H}]^{+}$calcd for $\mathrm{C}_{25} \mathrm{H}_{40} \mathrm{~N}_{3} \mathrm{O}_{4} \mathrm{Si}$ 474.2788; found 474.2775 .

Macrocycle 38. Diolefin 32 (30 mg, $0.08 \mathrm{mmol}, 1.0$ equiv), Hoveyda-Grubbs $2^{\text {nd }}$ generation catalyst $(5.0 \mathrm{mg}, 0.01 \mathrm{mmol}, 0.10$ equiv) and $p$-benzoquinone $(1.0 \mathrm{mg}, 0.01 \mathrm{mmol}, 0.10$ equiv) were dissolved in degassed $\mathrm{CH}_{2} \mathrm{Cl}_{2}(4 \mathrm{~mL}, 0.02 \mathrm{M})$ and the reaction mixture was heated at $40{ }^{\circ} \mathrm{C}$ for $15 \mathrm{~h}$. After this time, the solvent was removed under reduced pressure and the resulting crude product was purified by flash column chromatography (silica gel, $\mathrm{CH}_{2} \mathrm{Cl}_{2}$ $\rightarrow 5 \% \mathrm{MeOH}$ in $\left.\mathrm{CH}_{2} \mathrm{Cl}_{2}\right)$ to obtain macrocycle $38(21 \mathrm{mg}, 73 \%$, 1:1 mixture of diastereoisomers) as a white solid. Data assigned for the mixture of diastereoisomers: $\mathbf{R}_{f}=$ 0.46 (silica gel, $10 \% \mathrm{MeOH}$ in $\mathrm{CH}_{2} \mathrm{Cl}_{2}$ ); mp $=153-154{ }^{\circ} \mathrm{C} ;{ }^{1} \mathrm{H} \mathrm{NMR}\left(400 \mathrm{MHz}, \mathrm{CDCl}_{3}\right) \delta$ (ppm) $7.58(\mathrm{dd}, J=14.1,8.0 \mathrm{~Hz}, 2 \mathrm{H}), 7.45-7.38(\mathrm{~m}, 2 \mathrm{H}), 7.30-7.20(\mathrm{~m}, 4 \mathrm{H}), 5.78-5.68$ 
(m, $1 \mathrm{H}), 5.58-5.51(\mathrm{~m}, 1 \mathrm{H}), 5.35(\mathrm{dt}, J=14.6,6.9 \mathrm{~Hz}, 1 \mathrm{H}), 5.15(\mathrm{~d}, J=6.5 \mathrm{~Hz}, 1 \mathrm{H}), 5.10$ $(\mathrm{d}, J=6.9 \mathrm{~Hz}, 1 \mathrm{H}), 4.53(\mathrm{q}, J=7.1 \mathrm{~Hz}, 1 \mathrm{H}), 4.31(\mathrm{q}, J=7.3 \mathrm{~Hz}, 1 \mathrm{H}), 4.15(\mathrm{~d}, J=14.8 \mathrm{~Hz}$, $1 \mathrm{H}), 3.89(\mathrm{~d}, J=15.6 \mathrm{~Hz}, 1 \mathrm{H}), 3.75(\mathrm{~d}, J=15.4 \mathrm{~Hz}, 1 \mathrm{H}), 3.52(\mathrm{~d}, J=14.8 \mathrm{~Hz}, 1 \mathrm{H}), 2.53-$ $2.44(\mathrm{~m}, 4 \mathrm{H}), 2.41-2.26(\mathrm{~m}, 4 \mathrm{H}), 1.48(\mathrm{~d}, J=7.4 \mathrm{~Hz}, 3 \mathrm{H}), 1.46(\mathrm{~d}, J=7.2 \mathrm{~Hz}, 3 \mathrm{H}) ;{ }^{13} \mathrm{C}$ NMR $\left(100 \mathrm{MHz}, \mathrm{CDCl}_{3}\right) \delta(\mathrm{ppm}) 175.1,174.9,172.7,171.7,171.2,171.2,136.9,136.7$, $134.3,133.9,133.8,133.5,130.9,129.9,127.4,127.3,126.9,126.4,125.9,125.8,125.8$, 125.3, 71.9, 71.6, 50.9, 49.6, 43.6, 42.7, 34.9, 33.5, 28.5, 26.8, 15.8, 15.5; HRMS (H-ESI) $m / z:[\mathrm{M}+\mathrm{H}]^{+}$calcd for $\mathrm{C}_{17} \mathrm{H}_{22} \mathrm{~N}_{3} \mathrm{O}_{4} 332.1610$; found 332.1588.

Allylic Alcohol 41. To a solution of nitrobenzaldehyde derivative $\mathbf{4 0}^{19}$ (1.8 g, 6.99 mmol, 1.0 equiv) in THF $(25 \mathrm{~mL})$ was added vinylmagnesium bromide $(10 \mathrm{~mL}, 1.0 \mathrm{M}$ in THF, 9.79 mmol, 1.4 equiv) at $-78{ }^{\circ} \mathrm{C}$. After being stirred for $3.5 \mathrm{~h}$, the mixture was quenched with 25 $\mathrm{mL}$ of $0.01 \mathrm{~N} \mathrm{HCl}$, diluted and extracted with EtOAc three times. The combined organic layers were washed with brine, dried over anhydrous $\mathrm{MgSO}_{4}$, filtered and the solvent evaporated under reduced pressure. The crude product was purified by flash column chromatography (silica gel, 5\% EtOAc in hexanes) to obtain allylic alcohol $41(1.8 \mathrm{~g}, 90 \%)$ as a yellow oil: $\mathrm{R}_{f}=0.79$ (silica gel, $40 \%$ EtOAc in hexanes); ${ }^{1} \mathrm{H} \mathrm{NMR}\left(400 \mathrm{MHz}, \mathrm{CDCl}_{3}\right) \delta$ (ppm) $7.66(\mathrm{~d}, J=8.7 \mathrm{~Hz}, 1 \mathrm{H}), 7.53(\mathrm{~d}, J=2.7 \mathrm{~Hz}, 1 \mathrm{H}), 7.47-7.36(\mathrm{~m}, 6 \mathrm{H}), 7.25(\mathrm{dd}, J=$ 8.7, $2.7 \mathrm{~Hz}, 1 \mathrm{H}), 6.08(\mathrm{ddd}, J=17.2,10.5,5.1 \mathrm{~Hz}, 1 \mathrm{H}), 5.75-5.70(\mathrm{~m}, 1 \mathrm{H}), 5.43(\mathrm{dt}, J=$ 17.2, $1.4 \mathrm{~Hz}, 1 \mathrm{H}), 5.27(\mathrm{dt}, J=10.5,1.4 \mathrm{~Hz}, 1 \mathrm{H}), 5.14(\mathrm{~s}, 2 \mathrm{H}) ;{ }^{13} \mathrm{C} \mathrm{NMR}(100 \mathrm{MHz}$, $\left.\mathrm{CDCl}_{3}\right) \delta(\mathrm{ppm}) 158.3,148.9,138.1,135.7,130.2,129.8,128.8,128.5,127.6,120.7,115.9$ 110.3, 70.67, 69.7; HRMS (H-ESI) $m / z:[\mathrm{M}+\mathrm{H}]^{+}$calcd for $\mathrm{C}_{16} \mathrm{H}_{16} \mathrm{NO}_{4}$ 286.1079; found 286.1080. 
Silyl Ether 43. A solution of allylic alcohol 41 (800 mg, $4.47 \mathrm{mmol}, 1.0$ equiv) in $\mathrm{CH}_{2} \mathrm{Cl}_{2}$ (40 $\mathrm{mL}$ ) was treated with imidazole $(395 \mathrm{mg}, 5.80 \mathrm{mmol}, 1.3$ equiv) and TBSCl (875 mg, 5.80 mmol, 1.3 equiv) at $0{ }^{\circ} \mathrm{C}$. The resulting solution was stirred for $12 \mathrm{~h}$ at $25^{\circ} \mathrm{C}$ and then diluted with $\mathrm{CH}_{2} \mathrm{Cl}_{2}$, washed with a saturated aqueous $\mathrm{NH}_{4} \mathrm{Cl}$ solution and brine, dried over anhydrous $\mathrm{MgSO}_{4}$, filtered and the solvent evaporated under reduced pressure. The residue was purified by flash column chromatography (silica gel, 5\% EtOAc in hexanes) to obtain silyl ether $\mathbf{4 3}(1.2 \mathrm{~g}, 95 \%)$ as a colourless oil: $\mathrm{R}_{f}=0.88$ (silica gel, 40\% EtOAc in hexanes); ${ }^{1} \mathrm{H}$ NMR $\left(400 \mathrm{MHz}, \mathrm{CDCl}_{3}\right) \delta(\mathrm{ppm}) 7.74(\mathrm{~d}, J=8.8 \mathrm{~Hz}, 1 \mathrm{H}), 7.50(\mathrm{~d}, J=2.6 \mathrm{~Hz}, 1 \mathrm{H}), 7.47$ $-7.38(\mathrm{~m}, 5 \mathrm{H}), 7.25(\mathrm{dd}, J=8.8,2.7 \mathrm{~Hz}, 1 \mathrm{H}), 5.98(\mathrm{ddd}, J=17.0,10.3,5.0 \mathrm{~Hz}, 1 \mathrm{H}), 5.84$ $(\mathrm{dt}, J=5.0,1.4 \mathrm{~Hz}, 1 \mathrm{H}), 5.35(\mathrm{dt}, J=17.0,1.6 \mathrm{~Hz}, 1 \mathrm{H}), 5.13(\mathrm{~s}, 2 \mathrm{H}), 5.09(\mathrm{dt}, J=10.3,1.6$ $\mathrm{Hz}, 1 \mathrm{H}), 0.92(\mathrm{~s}, 9 \mathrm{H}), 0.13(\mathrm{~s}, 3 \mathrm{H}), 0.09$ (s, $3 \mathrm{H}) ;{ }^{13} \mathrm{C} \mathrm{NMR}\left(100 \mathrm{MHz}, \mathrm{CDCl}_{3}\right) \delta(\mathrm{ppm})$ $157.8,147.7,139.7,135.8,131.6,129.8,128.8,128.4,127.6,120.9,113.9,109.3,70.6,69.9$, 25.8, 18.3, -3.5; HRMS (H-ESI) $m / z:[\mathrm{M}+\mathrm{H}]^{+}$calcd for $\mathrm{C}_{22} \mathrm{H}_{30} \mathrm{NO}_{4} \mathrm{Si}$ 400.1944; found 400.1958 .

Benzyloxymethyl Acetal 45. To a solution of allylic alcohol 41 (460 mg, $1.61 \mathrm{mmol}, 1.0$ equiv) in $\mathrm{CH}_{2} \mathrm{Cl}_{2}(15 \mathrm{~mL})$ was added DIPEA (1.12 mL, $6.45 \mathrm{mmol}, 4.0$ equiv) and $\mathrm{BOMCl}$ (1.2 mL, $6.45 \mathrm{mmol}, 4.0$ equiv) at $0{ }^{\circ} \mathrm{C}$ and the mixture was stirred at $25^{\circ} \mathrm{C}$ for $15 \mathrm{~h}$. After this time, the reaction was quenched by addition of a saturated aqueous $\mathrm{Na}_{2} \mathrm{CO}_{3}$ solution and the crude mixture was stirred for $30 \mathrm{~min}$. Then, the aqueous phase was extracted with $\mathrm{CH}_{2} \mathrm{Cl}_{2}$ and the organic phase washed with brine, dried over anhydrous $\mathrm{MgSO}_{4}$, filtered and the solvent evaporated under reduced pressure. The resulting residue was purified by flash column chromatography (silica gel, 5\% EtOAc in hexanes) to obtain benzyloxymethyl acetal 45 (528 $\mathrm{mg}, 88 \%$ ) as a pale yellow oil: $\mathrm{R}_{f}=0.56$ (silica gel, $20 \%$ EtOAc in hexanes) ${ }^{1} \mathrm{H}$ NMR (400 
$\left.\mathrm{MHz}, \mathrm{CDCl}_{3}\right) \delta(\mathrm{ppm}) 7.65(\mathrm{~d}, J=8.8 \mathrm{~Hz}, 1 \mathrm{H}), 7.49(\mathrm{~d}, J=2.7 \mathrm{~Hz}, 1 \mathrm{H}), 7.43-7.28(\mathrm{~m}, 10$ H), $7.22(\mathrm{dd}, J=8.8,2.7 \mathrm{~Hz}, 1 \mathrm{H}), 5.95(\mathrm{ddd}, J=17.1,10.3,6.0 \mathrm{~Hz}, 1 \mathrm{H}), 5.79$ (d, $J=6.1 \mathrm{~Hz}$, $1 \mathrm{H}), 5.35(\mathrm{dt}, J=17.2,1.4 \mathrm{~Hz}, 1 \mathrm{H}), 5.23(\mathrm{dt}, J=10.4,1.3 \mathrm{~Hz}, 1 \mathrm{H}), 5.11(\mathrm{~s}, 2 \mathrm{H}), 4.91-$ $4.77(\mathrm{~m}, 2 \mathrm{H}), 4.71(\mathrm{~d}, J=6.9 \mathrm{~Hz}, 1 \mathrm{H}), 4.62-4.51(\mathrm{~m}, 2 \mathrm{H}) ;{ }^{13} \mathrm{C} \mathrm{NMR}\left(100 \mathrm{MHz}, \mathrm{CDCl}_{3}\right) \delta$ (ppm) 158.2, 148.9, 137.6, 136.8, 135.8, 129.9, 128.8, 128.5, 128.4, 128.4, 127.9, 127.7, 127.5, 120.6, 117.0, 109.8, 92.6, 73.4, 70.7, 69.8; HRMS (H-ESI) $m / z:[\mathrm{M}+\mathrm{H}]^{+}$calcd for $\mathrm{C}_{24} \mathrm{H}_{24} \mathrm{NO}_{5} 406.1655$; found 406.1651 .

Aniline 46. To a solution of benzyloxymethyl acetal 45 (480 mg, $1.18 \mathrm{mmol}, 1.0$ equiv) in EtOH $(10 \mathrm{~mL})$ was added a solution of $\mathrm{NH}_{4} \mathrm{Cl}(317 \mathrm{mg}, 5.92 \mathrm{mmol}, 5.0$ equiv) in water (7.5 $\mathrm{mL}$ ) followed by Zn dust (1.2 g, $17.76 \mathrm{mmol}, 15.0$ equiv) in twelve portions of $\sim 100 \mathrm{mg}$ each over $30 \mathrm{~min}$ at $25{ }^{\circ} \mathrm{C}$. The mixture was stirred at this temperature for $12 \mathrm{~h}$ and then the reaction mixture was diluted with $\mathrm{CH}_{2} \mathrm{Cl}_{2}$ and water, filtered and rinsed with $\mathrm{CH}_{2} \mathrm{Cl}_{2}$. The filtrate was diluted with water and extracted with $\mathrm{CH}_{2} \mathrm{Cl}_{2}$, and the organic phase washed with brine, dried over anhydrous $\mathrm{MgSO}_{4}$, filtered and the solvent evaporated under reduced pressure. The resulting residue was purified by flash column chromatography (silica gel, 15\% EtOAc in hexanes) to obtain aniline $46(351 \mathrm{mg}, 79 \%)$ as a pale yellow oil: $\mathrm{R}_{f}=0.35$ (silica gel, 30\% EtOAc in hexanes); ${ }^{1} \mathrm{H}$ NMR (400 MHz, $\left.\mathrm{CDCl}_{3}\right) \delta(\mathrm{ppm}) 7.42-7.29(\mathrm{~m}, 10 \mathrm{H})$, $7.01(\mathrm{~d}, J=8.4 \mathrm{~Hz}, 1 \mathrm{H}), 6.35(\mathrm{dd}, J=8.3,2.5 \mathrm{~Hz}, 1 \mathrm{H}), 6.29(\mathrm{~d}, J=2.5 \mathrm{~Hz}, 1 \mathrm{H}), 6.12$ (ddd, $J=17.2,10.4,5.7 \mathrm{~Hz}, 1 \mathrm{H}), 5.33(\mathrm{dt}, J=17.3,1.6 \mathrm{~Hz}, 1 \mathrm{H}), 5.25(\mathrm{dt}, J=10.4,1.6 \mathrm{~Hz}, 1 \mathrm{H})$, $5.16(\mathrm{dt}, J=5.7,1.5 \mathrm{~Hz}, 1 \mathrm{H}), 5.02(\mathrm{~s}, 2 \mathrm{H}), 4.84-4.76(\mathrm{~m}, 2 \mathrm{H}), 4.67-4.62(\mathrm{~m}, 2 \mathrm{H}), 4.16$ (bs, $2 \mathrm{H}) ;{ }^{13} \mathrm{C} \mathrm{NMR}\left(100 \mathrm{MHz}, \mathrm{CDCl}_{3}\right) \delta$ (ppm) 159.8, 146.7, 137.8, 137.2, 136.5, 130.6, $128.5,128.4,127.9,127.9,127.7,127.4,116.3,104.2,102.9,91.9,78.1,77.2,69.9,69.8$; HRMS (H-ESI) m/z: $[\mathrm{M}+\mathrm{H}]^{+}$calcd for $\mathrm{C}_{24} \mathrm{H}_{26} \mathrm{NO}_{3}$ 376.1913; found 376.1901. 
Diolefin 47. A solution of the aniline 46 (50 mg, $0.13 \mathrm{mmol}, 1.0$ equiv) and acid 36 (30 mg, $0.13 \mathrm{mmol}, 1.0$ equiv) in dry DMF (7 mL) was treated with HATU (50 mg, $0.13 \mathrm{mmol}, 1.0$ equiv) and DIPEA (22 $\mu \mathrm{L}, 0.13 \mathrm{mmol}, 1.0$ equiv) and the resulting solution was stirred at 25 ${ }^{\circ} \mathrm{C}$ for $12 \mathrm{~h}$. After this time, a saturated aqueous $\mathrm{NH}_{4} \mathrm{Cl}$ solution was added and the organic layer was separated. The aqueous phase was extracted with EtOAc, and the combined organic layers were washed with brine, dried over anhydrous $\mathrm{MgSO}_{4}$, filtered and the solvent evaporated under reduced pressure. The crude product was purified by flash column chromatography (silica gel, 30\% EtOAc in hexanes) to obtain diolefin 47 (57 mg, 75\%, 1:1 mixture of diastereoisomers) as a white solid. Data assigned for the mixture of diastereoisomers: $\mathrm{R}_{f}=0.81$ (silica gel, 80\% EtOAc in hexanes); $\mathrm{mp}=90-91{ }^{\circ} \mathrm{C} ;{ }^{1} \mathrm{H} \mathrm{NMR}$ $\left(400 \mathrm{MHz}, \mathrm{CDCl}_{3}\right) \delta(\mathrm{ppm}) 8.89(\mathrm{~d}, J=16.4 \mathrm{~Hz}, 1 \mathrm{H}), 7.98(\mathrm{~d}, J=2.5 \mathrm{~Hz}, 1 \mathrm{H}), 7.47-7.27$ $(\mathrm{m}, 11 \mathrm{H}), 7.08(\mathrm{dd}, J=8.5,1.8 \mathrm{~Hz}, 1 \mathrm{H}), 6.70(\mathrm{ddd}, J=8.5,2.6,1.2 \mathrm{~Hz}, 1 \mathrm{H}), 6.00(\mathrm{ddd}, J=$ 18.5, 9.3, 4.1 Hz, $1 \mathrm{H}), 5.83$ (dddd, $J=12.6,8.8,6.1,4.7 \mathrm{~Hz}, 1 \mathrm{H}), 5.30-5.20$ (m, $3 \mathrm{H}), 5.12$ $-4.99(\mathrm{~m}, 5 \mathrm{H}), 4.80(\mathrm{ddd}, J=15.5,11.0,6.7 \mathrm{~Hz}, 2 \mathrm{H}), 4.67(\mathrm{dd}, J=14.2,12.2 \mathrm{~Hz}, 1 \mathrm{H}), 4.59$ $-4.54(\mathrm{~m}, 2 \mathrm{H}), 2.44-2.37(\mathrm{~m}, 2 \mathrm{H}), 2.36-2.29(\mathrm{~m}, 2 \mathrm{H}), 1.45-1.38(\mathrm{~m}, 3 \mathrm{H}) ;{ }^{13} \mathrm{C} \mathrm{NMR}$ $\left(100 \mathrm{MHz}, \mathrm{CDCl}_{3}\right) \delta(\mathrm{ppm}) 176.3,171.9,171.9,170.5,170.4,159.4,137.5,137.4,137.2$, $136.9,136.8,136.4,136.4,130.4,128.6,128.6,128.5,128.1,128.1,128.0,127.6,120.2$, $120.2,116.8,116.8,115.8,115.7,115.6,111.1,111.0,108.6,108.5,92.2,92.0,78.2,78.2$, 70.2, 70.1, 49.8, 49.7, 38.6, 35.7, 33.0, 29.4, 28.7, 19.1, 18.9; HRMS (H-ESI) m/z: $[\mathrm{M}+\mathrm{H}]^{+}$ calcd for $\mathrm{C}_{34} \mathrm{H}_{40} \mathrm{~N}_{3} \mathrm{O}_{6} 586.2917$; found 586.2921.

Macrocycle 48. Diolefin 47 (15 mg, $0.03 \mathrm{mmol}, 1.0$ equiv), Hoveyda-Grubbs $2^{\text {nd }}$ generation catalyst (1.6 mg, $0.003 \mathrm{mmol}, 0.10$ equiv) and p-benzoquinone $(1.0 \mathrm{mg}, 0.003 \mathrm{mmol}, 0.10$ 
equiv) were dissolved in degassed $\mathrm{CH}_{2} \mathrm{Cl}_{2}(2 \mathrm{~mL}, 0.02 \mathrm{M})$ and the reaction mixture was heated at $40{ }^{\circ} \mathrm{C}$ for $15 \mathrm{~h}$. After this time, the solvent was removed under reduced pressure and the resulting crude product was purified by flash column chromatography (silica gel, 20\% EtOAc in hexanes $\rightarrow 60 \%$ EtOAc in hexanes) to obtain macrocycle 48 (12 mg, 84\%, 1:1 mixture of diastereoisomers) as a white solid. Data assigned for the mixture of diastereoisomers: $\mathrm{R}_{f}=0.21$ (silica gel, 80\% EtOAc in hexanes); $\mathrm{mp}=207-208{ }^{\circ} \mathrm{C} ;{ }^{1} \mathrm{H}$ NMR $\left(400 \mathrm{MHz}, \mathrm{CDCl}_{3}\right) \delta(\mathrm{ppm}) 8.81(\mathrm{bs}, 1 \mathrm{H}), 8.53(\mathrm{bs}, 1 \mathrm{H}), 8.51(\mathrm{~d}, J=2.6 \mathrm{~Hz}, 1 \mathrm{H}), 8.35(\mathrm{~d}, J$ $=2.6 \mathrm{~Hz}, 1 \mathrm{H}), 7.46-7.28(\mathrm{~m}, 23 \mathrm{H}), 7.04(\mathrm{~d}, J=8.4 \mathrm{~Hz}, 1 \mathrm{H}), 6.70(\mathrm{dd}, J=8.5,2.6 \mathrm{~Hz}, 1$ H), $6.61(\mathrm{dd}, J=8.3,2.6 \mathrm{~Hz}, 1 \mathrm{H}), 6.20-6.11(\mathrm{~m}, 1 \mathrm{H}), 6.08-5.98(\mathrm{~m}, 2 \mathrm{H}), 5.82-5.72(\mathrm{~m}$, $2 \mathrm{H}), 5.60(\mathrm{dd}, J=15.4,5.7 \mathrm{~Hz}, 1 \mathrm{H}), 5.20-5.16(\mathrm{~m}, 1 \mathrm{H}), 5.15-5.10(\mathrm{~m}, 1 \mathrm{H}), 5.07$ (s, 4 H), $4.91-4.74(\mathrm{~m}, 4 \mathrm{H}), 4.71-4.63(\mathrm{~m}, 4 \mathrm{H}), 4.60(\mathrm{~d}, J=7.5 \mathrm{~Hz}, 2 \mathrm{H}), 4.52-4.43(\mathrm{~m}, 2 \mathrm{H})$, $2.51(\mathrm{dd}, J=9.1,4.1 \mathrm{~Hz}, 4 \mathrm{H}), 2.39-2.20(\mathrm{~m}, 4 \mathrm{H}), 1.54(\mathrm{~d}, J=7.2 \mathrm{~Hz}, 3 \mathrm{H}), 1.49(\mathrm{~d}, J=7.4$ $\mathrm{Hz}, 3 \mathrm{H}) ;{ }^{13} \mathrm{C} \mathrm{NMR}\left(100 \mathrm{MHz}, \mathrm{CDCl}_{3}\right) \delta(\mathrm{ppm}) 172.7,172.7,172.2,170.4,170.3,169.5$, $159.8,159.2,138.7,138.1,137.7,136.9,136.9,132.4,132.3,132.0,131.6,128.7,128.6$, $128.5,128.5,128.5,128.1,127.9,127.9,127.9,127.9,127.8,127.7,127.6,127.6,127.5$, $119.8,118.3,110.7,109.9,106.9,106.7,91.5,90.9,75.9,74.5,69.9,69.9,69.7,69.5,51.8$, 51.5, 50.9, 36.9, 36.4, 30.2, 29.7, 29.6, 17.9, 16.5; HRMS (H-ESI) $m / z:[\mathrm{M}+\mathrm{H}]^{+}$calcd for $\mathrm{C}_{32} \mathrm{H}_{36} \mathrm{~N}_{3} \mathrm{O}_{6}$ 558.2604; found 558.2615.

Acid 49. A $5 \mathrm{~mL}$ polypropylene syringe fitted with polyethylene porous disk charged with 2chlorotrityl chloride (CTC) resin (363 mg, L=1.3 mmol/g, $0.47 \mathrm{mmol}, 1.0$ equiv), was loaded with a solution of Fmoc-D-Ala-OH (34) (441 mg, 1.42 mmol, 3.0 equiv) and DIPEA (0.29 $\mathrm{mL}, 1.65 \mathrm{mmol}, 3.5$ equiv) in dry DMF (3 mL). The resulting suspension was shaken at 280 rpm for $30 \mathrm{~h}$, then the solution was unloaded and the resin was washed by shaking with dry 
DMF $(5 \times 3 \mathrm{~mL})$. The resulting yellow resin was used in the subsequent step. The polypropylene syringe loaded with the yellow resin was treated with a solution of $20 \%$ piperidine in DMF (3 x $3 \mathrm{~mL}$ x $10 \mathrm{~min}$ at $280 \mathrm{rpm}$ ). After the last run, the resin was washed with dry DMF (5 x $3 \mathrm{~mL}$ ) and loaded with a solution of Fmoc-Gly-OH (35) (281 mg, 0.94 mmol, 2.0 equiv), HOBt (128 mg, $0.94 \mathrm{mmol}, 2.0$ equiv) and DIC (0.18 mL, $1.18 \mathrm{mmol}, 2.5$ equiv) in dry DMF (3 mL). The resulting suspension was shaken at $280 \mathrm{rpm}$ for $24 \mathrm{~h}$, and then the solution was unloaded and the resin washed with dry DMF (5 x $3 \mathrm{~mL})$. The resulting yellow resin was used in the next step. To a $5 \mathrm{~mL}$ polypropylene syringe fitted with polyethylene porous disk and loaded with the Fmoc protected dipeptide resin was added a solution of $20 \%$ piperidine in DMF (3 x $3 \mathrm{~mL}$ x $10 \mathrm{~min}$ at $280 \mathrm{rpm}$ ). After the last run, the resin was washed with dry DMF (5 x $3 \mathrm{~mL})$ and treated with a solution of the acid $\mathbf{1 4}(231$ mg, $0.94 \mathrm{mmol}, 2.0$ equiv), HOBt (127 mg, $0.94 \mathrm{mmol}, 2.0$ equiv) and DIC (0.18 mL, 1.18 mmol, 2.5 equiv) in dry DMF (3 mL). The resulting suspension was shaken at $280 \mathrm{rpm}$ for 24 $\mathrm{h}$, and then the solution was unloaded and the resin washed with dry DMF (5 x $3 \mathrm{~mL})$. The resulting yellow resin was treated with a solution of $\mathrm{CH}_{2} \mathrm{Cl}_{2} / \mathrm{AcOH} / \mathrm{TFE}(7: 2: 1,3 \mathrm{~mL})$ for 30 min. After that, the solution was collected and the resin washed with $\mathrm{CH}_{2} \mathrm{Cl}_{2}(2 \times 3 \mathrm{~mL})$. All the collected organic solvents were evaporated under reduced pressure and the resulting acid 49 (90 mg, 84\% overall yield from CTC resin) was obtained as a colorless solid which not required further purification: $\mathrm{R}_{f}=0.30$ (silica gel, $10 \% \mathrm{MeOH}$ in $\left.\mathrm{CH}_{2} \mathrm{Cl}_{2}\right) ;[\alpha]^{25} \mathrm{D}=-5.44(c$ $\left.0.08, \mathrm{CH}_{2} \mathrm{Cl}_{2}\right) ; \mathrm{mp}=92-93{ }^{\circ} \mathrm{C} ;{ }^{1} \mathrm{H} \mathrm{NMR}\left(400 \mathrm{MHz}, \mathrm{CDCl}_{3}\right) \delta(\mathrm{ppm}) 7.20(\mathrm{~d}, J=5.7 \mathrm{~Hz}, 1 \mathrm{H})$, $5.76(\mathrm{ddd}, J=17.2,10.4,6.8 \mathrm{~Hz}, 1 \mathrm{H}), 5.20(\mathrm{~d}, J=17.1 \mathrm{~Hz}, 1 \mathrm{H}), 5.15(\mathrm{~d}, J=10.5 \mathrm{~Hz}, 1 \mathrm{H})$, $4.61-4.47(\mathrm{~m}, 1 \mathrm{H}), 4.17(\mathrm{~d}, J=6.5 \mathrm{~Hz}, 1 \mathrm{H}), 4.08(\mathrm{dd}, J=16.6,5.7 \mathrm{~Hz}, 1 \mathrm{H}), 3.86(\mathrm{dd}, J=$ 16.6, $4.8 \mathrm{~Hz}, 1 \mathrm{H}), 2.41(\mathrm{p}, J=6.9 \mathrm{~Hz}, 1 \mathrm{H}), 1.42(\mathrm{~d}, J=7.0 \mathrm{~Hz}, 3 \mathrm{H}), 1.11(\mathrm{~d}, J=7.1 \mathrm{~Hz}, 3$ $\mathrm{H}), 0.86(\mathrm{~s}, 9 \mathrm{H}), 0.03(\mathrm{~s}, 3 \mathrm{H}), 0.02(\mathrm{~s}, 3 \mathrm{H}) ;{ }^{13} \mathrm{C} \mathrm{NMR}\left(100 \mathrm{MHz}, \mathrm{CDCl}_{3}\right) \delta(\mathrm{ppm}) 175.9$, 
$168.8,163.2,138.8,116.6,76.0,47.8,42.9,36.8,25.8,18.1,18.0,14.7,-4.3,-5.1$; HRMS (HESI) $m / z:[\mathrm{M}+\mathrm{H}]^{+}$calcd for $\mathrm{C}_{17} \mathrm{H}_{33} \mathrm{~N}_{2} \mathrm{O}_{5} \mathrm{Si} 373.2159$; found 373.2164.

Diolefin 51. To a solution of aniline 30 (64 mg, $0.43 \mathrm{mmol}, 1.0$ equiv) and acid 49 (160 mg, $043 \mathrm{mmol}, 1.3$ equiv) in DMF (10 mL) was added HATU (163 mg, $0.43 \mathrm{mmol}, 1.0$ equiv) and DIPEA $\left(0.10 \mathrm{~mL}, 0.43 \mathrm{mmol}, 1.0\right.$ equiv) at $0{ }^{\circ} \mathrm{C}$ and the mixture was stirred for $12 \mathrm{~h}$ at $25^{\circ} \mathrm{C}$. After this time, a saturated aqueous $\mathrm{NH}_{4} \mathrm{Cl}$ solution was added and the organic layer was separated. The aqueous phase was extracted with EtOAc, and the combined organic layers were washed with brine, dried over anhydrous $\mathrm{MgSO}_{4}$, filtered and the solvent evaporated under reduced pressure. The crude product was purified by flash column chromatography (silica gel, 25\% EtOAc in hexanes $\rightarrow$ 100\% EtOAc) to obtain diolefin 51 (60 mg, 36\%, 1:1 mixture of diastereoisomers) as a white foam. Data assigned for the mixture of diastereoisomers: $\mathrm{R}_{f}=0.23$ (silica gel, $100 \%$ EtOAc); ${ }^{1} \mathrm{H}$ NMR $\left(400 \mathrm{MHz}, \mathrm{CDCl}_{3}\right) \delta(\mathrm{ppm})$ $7.28-7.19(\mathrm{~m}, 2 \mathrm{H}), 7.17-7.10(\mathrm{~m}, 1 \mathrm{H}), 7.05(\mathrm{t}, J=7.3 \mathrm{~Hz}, 1 \mathrm{H}), 6.14-5.96(\mathrm{~m}, 1 \mathrm{H})$, $5.78-5.61(\mathrm{~m}, 1 \mathrm{H}), 5.32-5.06(\mathrm{~m}, 5 \mathrm{H}), 4.43-4.25(\mathrm{~m}, 1 \mathrm{H}), 4.18-4.07(\mathrm{~m}, 1 \mathrm{H}), 3.99(\mathrm{~s}$, $1 \mathrm{H}), 3.69-3.55(\mathrm{~m}, 1 \mathrm{H}), 2.44(\mathrm{~s}, 1 \mathrm{H}), 2.35-2.22(\mathrm{~m}, 1 \mathrm{H}), 1.36(\mathrm{~d}, J=5.7 \mathrm{~Hz}, 3 \mathrm{H}), 1.00$ $-0.94(\mathrm{~m}, 3 \mathrm{H}) ;{ }^{13} \mathrm{C} \mathrm{NMR}\left(100 \mathrm{MHz}, \mathrm{CDCl}_{3}\right) \delta(\mathrm{ppm}) 176.9,176.5,171.6,171.2,170.7$, $170.5,138.1,137.9,137.8,136.1,131.4,131.1,128.6,128.5,128.2,128.1,124.8,124.8$, $122.6,122.3,118.4,118.0,116.7,116.2,74.9,74.3,60.5,50.5,49.5,46.8,46.8,30.7,29.7$, 17.4, 17.3, 13.8, 13.5; HRMS (H-ESI) $m / z:[\mathrm{M}+\mathrm{H}]^{+}$calcd for $\mathrm{C}_{20} \mathrm{H}_{28} \mathrm{~N}_{3} \mathrm{O}_{5}$ 390.2029; found 390.2037 .

Ketone 53. To a solution of diolefin $32\left(27 \mathrm{mg}, 0.08 \mathrm{mmol}, 1.0\right.$ equiv) in $\mathrm{CH}_{2} \mathrm{Cl}_{2}(15 \mathrm{~mL})$ was added $\mathrm{MnO}_{2}\left(131 \mathrm{mg}, 1.50 \mathrm{mmol}, 20.0\right.$ equiv) and the dark solution was stirred at $25^{\circ} \mathrm{C}$ 
for $48 \mathrm{~h}$. The mixture was filtered through a pad of celite and rinsed with $\mathrm{CH}_{2} \mathrm{Cl}_{2}$. The solvent was evaporated under reduced pressure to obtain ketone $\mathbf{5 3}(20 \mathrm{mg}, 75 \%)$ as a white solid which did not require purification: $\mathrm{R}_{f}=0.43$ (silica gel, $100 \%$ EtOAc); $[\alpha]^{25} \mathrm{D}=-6.98(c$ 0.09, $\left.\mathrm{CH}_{2} \mathrm{Cl}_{2}\right) ; \mathrm{mp}=111-112{ }^{\circ} \mathrm{C} ;{ }^{1} \mathrm{H}$ NMR $\left(400 \mathrm{MHz}, \mathrm{CDCl}_{3}\right) \delta(\mathrm{ppm}) 11.91$ (bs, $\left.1 \mathrm{H}\right), 8.72$ $(\mathrm{dd}, J=8.5,1.0 \mathrm{~Hz}, 1 \mathrm{H}), 7.90(\mathrm{dd}, J=8.0,1.6 \mathrm{~Hz}, 1 \mathrm{H}), 7.59(\mathrm{ddd}, J=8.6,7.5,1.4 \mathrm{~Hz}, 1 \mathrm{H})$, $7.26-7.15(\mathrm{~m}, 2 \mathrm{H}), 7.04(\mathrm{~d}, J=7.2 \mathrm{~Hz}, 1 \mathrm{H}), 6.73(\mathrm{t}, J=4.9 \mathrm{~Hz}, 1 \mathrm{H}), 6.42(\mathrm{dd}, J=16.9$, $1.6 \mathrm{~Hz}, 1 \mathrm{H}), 5.98(\mathrm{dd}, J=10.6,1.6 \mathrm{~Hz}, 1 \mathrm{H}), 5.91-5.77(\mathrm{~m}, 1 \mathrm{H}), 5.08(\mathrm{ddd}, J=17.1,3.2$, $1.6 \mathrm{~Hz}, 1 \mathrm{H}), 5.01(\mathrm{ddd}, J=2.9,2.4,1.2 \mathrm{~Hz}, 1 \mathrm{H}), 4.67(\mathrm{p}, J=7.2 \mathrm{~Hz}, 1 \mathrm{H}), 4.32(\mathrm{dd}, J=$ 16.8, $5.8 \mathrm{~Hz}, 1 \mathrm{H}), 4.06(\mathrm{dd}, J=16.8,4.8 \mathrm{~Hz}, 1 \mathrm{H}), 2.45-2.35(\mathrm{~m}, 4 \mathrm{H}), 1.54(\mathrm{~d}, J=7.2 \mathrm{~Hz}$, $3 \mathrm{H}) ;{ }^{13} \mathrm{C} \mathrm{NMR}\left(100 \mathrm{MHz}, \mathrm{CDCl}_{3}\right) \delta(\mathrm{ppm}) 194.2,172.9,171.3,169.2,140.7,136.9,135.3$, 133.0, 131.3, 131.0, 122.9, 122.5, 121.0, 115.8, 50.4, 43.3, 35.5, 29.4, 18.2; HRMS (H-ESI) $m / z:[\mathrm{M}+\mathrm{H}]^{+}$calcd for $\mathrm{C}_{19} \mathrm{H}_{24} \mathrm{~N}_{3} \mathrm{O}_{4} 358.1767$; found 358.1789.

Dipeptide 61. To a solution of aniline $\mathbf{6 0}^{23}$ (200 mg, $1.68 \mathrm{mmol}, 1.0$ equiv) and Boc-Gly-DAla-OH (21) (413 mg, $1.68 \mathrm{mmol}, 1.0$ equiv) in DMF (10 mL) was added HATU (960 mg, $2.52 \mathrm{mmol}, 1.5$ equiv) and DIPEA (0.30 mL, $1.68 \mathrm{mmol}, 1.0$ equiv) and the mixture was stirred for $12 \mathrm{~h}$ at $25{ }^{\circ} \mathrm{C}$. After this time, the reaction mixture was diluted with $\mathrm{CH}_{2} \mathrm{Cl}_{2}$ and washed sequentially with $1 \mathrm{~N} \mathrm{HCl}$ and saturated aqueous $\mathrm{NaHCO}_{3}$ solution. The organic layer was separated, washed with brine and dried over anhydrous $\mathrm{MgSO}_{4}$, filtered and the solvent evaporated under reduced pressure. The crude product was purified by flash column chromatography (silica gel, 30\% EtOAc in hexanes) to obtain dipeptide 61 (455 mg, 78\%) as a white solid: $\mathrm{R}_{f}=0.52$ (silica gel, $100 \%$ EtOAc); $[\alpha]^{25} \mathrm{D}=-6.36\left(c 0.06, \mathrm{CH}_{2} \mathrm{Cl}_{2}\right) ; \mathrm{mp}=84-$ $85{ }^{\circ} \mathrm{C} ;{ }^{1} \mathrm{H}$ NMR $\left(400 \mathrm{MHz}, \mathrm{CDCl}_{3}\right) \delta(\mathrm{ppm}) 8.13(\mathrm{bs}, 1 \mathrm{H}), 7.78(\mathrm{~d}, J=8.1 \mathrm{~Hz}, 1 \mathrm{H}), 7.45(\mathrm{~d}$, $J=7.8 \mathrm{~Hz}, 1 \mathrm{H}), 7.15(\mathrm{t}, J=7.5 \mathrm{~Hz}, 1 \mathrm{H}), 6.85-6.79(\mathrm{~m}, 1 \mathrm{H}), 6.76(\mathrm{~d}, J=9.1 \mathrm{~Hz}, 1 \mathrm{H}), 5.68$ 
$(\mathrm{dd}, J=17.4,1.2 \mathrm{~Hz}, 1 \mathrm{H}), 5.43(\mathrm{dd}, J=11.0,1.2 \mathrm{~Hz}, 1 \mathrm{H}), 5.12(\mathrm{bs}, 1 \mathrm{H}), 4.66(\mathrm{q}, J=7.1$ $\mathrm{Hz}, 1 \mathrm{H}), 3.92-3.77(\mathrm{~m}, 2 \mathrm{H}), 1.50(\mathrm{~d}, J=7.0 \mathrm{~Hz}, 3 \mathrm{H}), 1.44(\mathrm{~s}, 9 \mathrm{H}) ;{ }^{13} \mathrm{C}$ NMR $(100 \mathrm{MHz}$, $\left.\mathrm{CDCl}_{3}\right) \delta(\mathrm{ppm}) 170.4,170.0,156.1,136.9,136.2,131.1,130.1,127.2,125.7,123.9,116.5$ 49.5, 38.6, 36.1, 28.2, 17.7; HRMS (H-ESI) $m / z:[\mathrm{M}+\mathrm{H}]^{+}$calcd for $\mathrm{C}_{18} \mathrm{H}_{26} \mathrm{~N}_{3} \mathrm{O}_{4} 348.1923$; found 348.1921.

Diolefin 63. Dipeptide 61 (152 mg, $0.44 \mathrm{mmol}, 1.0$ equiv) in $\mathrm{CH}_{2} \mathrm{Cl}_{2}(25 \mathrm{~mL})$ was treated with TFA $(2.2 \mathrm{~mL})$ in exactly the same manner as previously described for synthesis of $\mathbf{2 4}$. A solution of the ammonium salt and acid $\mathbf{6 2}^{10,24}$ (50 $\mathrm{mg}, 0.44 \mathrm{mmol}, 1.0$ equiv), in DMF (15 $\mathrm{mL})$ was treated with HATU (167 mg, $0.44 \mathrm{mmol}, 1.0$ equiv) and DIPEA (0.23 mL, 1.31 mmol, 3.0 equiv) and the resulting reaction mixture was stirred at $25^{\circ} \mathrm{C}$ for $12 \mathrm{~h}$. After this time, a saturated aqueous $\mathrm{NH}_{4} \mathrm{Cl}$ solution was added and the organic layer was separated. The aqueous phase was extracted with EtOAc, and the combined organic layers were washed with brine and dried over anhydrous $\mathrm{MgSO}_{4}$, filtered and the solvent evaporated under reduced pressure. The crude product was purified by flash column chromatography (silica gel, $\mathrm{CH}_{2} \mathrm{Cl}_{2}$ $\rightarrow 2 \% \mathrm{MeOH}$ in $\mathrm{CH}_{2} \mathrm{Cl}_{2}$ ) to obtain diolefin 63 (150 mg, $92 \%$ over two steps) as a white solid: $\mathrm{R}_{f}=0.60$ (silica gel, $10 \% \mathrm{MeOH}$ in $\left.\mathrm{CH}_{2} \mathrm{Cl}_{2}\right) ;[\alpha]^{25} \mathrm{D}=-5.43\left(c 0.07, \mathrm{CH}_{2} \mathrm{Cl}_{2}\right) ; \mathrm{mp}=104-105$ ${ }^{\circ} \mathrm{C} ;{ }^{1} \mathrm{H} \mathrm{NMR}\left(400 \mathrm{MHz}, \mathrm{CDCl}_{3}\right) \delta(\mathrm{ppm}) 8.34(\mathrm{bs}, 1 \mathrm{H}), 7.67-7.57(\mathrm{~m}, 1 \mathrm{H}), 7.46(\mathrm{~d}, J=7.6$ $\mathrm{Hz}, 1 \mathrm{H}), 7.26-7.13(\mathrm{~m}, 2 \mathrm{H}), 6.82-6.71(\mathrm{~m}, 1 \mathrm{H}), 6.68(\mathrm{t}, J=7.6 \mathrm{~Hz}, 1 \mathrm{H}), 6.46(\mathrm{bs}, 1 \mathrm{H})$, $5.81(\mathrm{td}, J=16.9,7.7 \mathrm{~Hz}, 1 \mathrm{H}), 5.67(\mathrm{dd}, J=17.4,1.1 \mathrm{~Hz}, 1 \mathrm{H}), 5.42-5.34(\mathrm{~m}, 2 \mathrm{H}), 5.18-$ $5.12(\mathrm{~m}, 1 \mathrm{H}), 4.67-4.51(\mathrm{~m}, 1 \mathrm{H}), 4.25(\mathrm{dd}, J=16.7,7.3 \mathrm{~Hz}, 1 \mathrm{H}), 3.79-3.62(\mathrm{~m}, 2 \mathrm{H})$, $3.14(\mathrm{qd}, J=7.3,4.4 \mathrm{~Hz}, 2 \mathrm{H}), 2.17(\mathrm{dd}, J=13.7,8.2 \mathrm{~Hz}, 1 \mathrm{H}), 1.42(\mathrm{~d}, J=6.7 \mathrm{~Hz}, 3 \mathrm{H}), 1.39$ $(\mathrm{d}, J=6.6 \mathrm{~Hz}, 3 \mathrm{H}) ;{ }^{13} \mathrm{C} \mathrm{NMR}\left(100 \mathrm{MHz}, \mathrm{CDCl}_{3}\right) \delta(\mathrm{ppm}) 176.1,171.2,170.2,133.5,131.8$, 


\begin{abstract}
$128.3,126.4,126.1,126.0,124.5,124.1,119.0,117.5,73.3,55.6,43.5,39.2,18.6,17.2,12.4$.
HRMS (H-ESI) $m / z:[\mathrm{M}+\mathrm{H}]^{+}$calcd for $\mathrm{C}_{20} \mathrm{H}_{28} \mathrm{~N}_{3} \mathrm{O}_{4}$ 374.2080; found 374.2072.
\end{abstract}

Styryl 65. To a solution of iodonitrobenzene 18 (2.7 g, $7.60 \mathrm{mmol}, 1.0$ equiv) and $\mathrm{Pd}\left[\mathrm{PPh}_{3}\right]_{4}$ (1.3 g, $1.14 \mathrm{mmol}, 0.15$ equiv) in DMF (10 mL) was added dropwise tri- $n$-butyl(vinyl)tin (2.7 $\mathrm{mL}, 9.12 \mathrm{mmol}, 1.2$ equiv). The solution was then heated at $60{ }^{\circ} \mathrm{C}$ for $48 \mathrm{~h}$. After this time, the mixture was diluted with $\mathrm{Et}_{2} \mathrm{O}$ and water. The organic layer was separated and washed with water four times, dried over anhydrous $\mathrm{MgSO}_{4}$, filtered and the solvent evaporated under reduced pressure. The crude product was purified by flash column chromatography (silica gel, $2 \%$ EtOAc in Hexanes) to obtain styryl $\mathbf{6 5}(1.4 \mathrm{~g}, 74 \%)$ as a yellow oil: $\mathrm{R}_{f}=0.51$ (silica gel, $20 \%$ EtOAc in hexanes); ${ }^{1} \mathrm{H}$ NMR $\left(400 \mathrm{MHz}, \mathrm{CDCl}_{3}\right) \delta(\mathrm{ppm}) 7.54$ (dd, $J=10.3,5.7 \mathrm{~Hz}, 2$ H), $7.46-7.34(\mathrm{~m}, 5 \mathrm{H}), 7.20(\mathrm{ddd}, J=8.7,2.7,0.6 \mathrm{~Hz}, 1 \mathrm{H}), 7.11(\mathrm{ddd}, J=11.5,10.9,5.5$ $\mathrm{Hz}, 1 \mathrm{H}), 5.65(\mathrm{dd}, J=17.3,1.0 \mathrm{~Hz}, 1 \mathrm{H}), 5.40(\mathrm{dd}, J=11.0,1.0 \mathrm{~Hz}, 1 \mathrm{H}), 5.13(\mathrm{~s}, 2 \mathrm{H}) ;{ }^{13} \mathrm{C}$ NMR $\left(100 \mathrm{MHz}, \mathrm{CDCl}_{3}\right) \delta(\mathrm{ppm}) 158.4,135.7,132.0,129.5,128.8,128.7,128.5,127.6$, 126.1, 120.8, 117.4, 109.8, 70.7; HRMS (H-ESI) $m / z:[\mathrm{M}+\mathrm{H}]^{+}$calcd for $\mathrm{C}_{15} \mathrm{H}_{14} \mathrm{NO}_{3}$ 256.0974; found 256.0981.

Aniline 66. To a solution of styryl 65 (550 mg, $2.16 \mathrm{mmol}, 1.0$ equiv) in EtOH (20 mL) was added a solution of $\mathrm{NH}_{4} \mathrm{Cl}(576 \mathrm{mg}, 10.77 \mathrm{mmol}, 5.0$ equiv) in water (14 mL) followed by $\mathrm{Zn}$ dust (2.1 g, $32.32 \mathrm{mmol}, 15.0$ equiv) in ten portions of $\sim 200 \mathrm{mg}$ each over $30 \mathrm{~min}$ at $25^{\circ} \mathrm{C}$. The mixture was stirred at this temperature for $12 \mathrm{~h}$ and then the reaction mixture was diluted with $\mathrm{CH}_{2} \mathrm{Cl}_{2}$ and water, filtered and rinsed with $\mathrm{CH}_{2} \mathrm{Cl}_{2}$. The filtrate was diluted with water and extracted with $\mathrm{CH}_{2} \mathrm{Cl}_{2}$, and the organic phase washed with brine, dried over anhydrous $\mathrm{MgSO}_{4}$, filtered and the solvent evaporated under reduced pressure. The resulting residue was 
purified by flash column chromatography (silica gel, 10\% EtOAc in hexanes) to obtain aniline 66 (413 mg, 85\%) as a yellow oil: $\mathrm{R}_{f}=0.47$ (silica gel, 30\% EtOAc in hexanes); ${ }^{1} \mathrm{H}$ NMR $\left(400 \mathrm{MHz}, \mathrm{CDCl}_{3}\right) \delta(\mathrm{ppm}) 7.45-7.31(\mathrm{~m}, 5 \mathrm{H}), 7.27-7.21(\mathrm{~m}, 1 \mathrm{H}), 6.71(\mathrm{dd}, J=17.4$, $11.1 \mathrm{~Hz}, 1 \mathrm{H}), 6.44(\mathrm{dd}, J=8.5,2.4 \mathrm{~Hz}, 1 \mathrm{H}), 6.32(\mathrm{~d}, J=2.5 \mathrm{~Hz}, 1 \mathrm{H}), 5.54(\mathrm{dd}, J=17.4,1.5$ $\mathrm{Hz}, 1 \mathrm{H}), 5.22(\mathrm{dd}, J=11.0,1.5 \mathrm{~Hz}, 1 \mathrm{H}), 5.04(\mathrm{~s}, 2 \mathrm{H}), 3.78(\mathrm{bs}, 2 \mathrm{H}) ;{ }^{13} \mathrm{C}$ NMR $(100 \mathrm{MHz}$, $\left.\mathrm{CDCl}_{3}\right) \delta(\mathrm{ppm}) 159.6,144.9,137.2,132.2,128.6,128.5,127.9,127.4,117.5,113.8,105.7$ 102.3, 69.9; HRMS (H-ESI) $m / z:[\mathrm{M}+\mathrm{H}]^{+}$calcd for $\mathrm{C}_{15} \mathrm{H}_{16} \mathrm{NO} 226.1232$; found 226.1229.

Dipeptide 67. To a solution of aniline 66 (340 mg, $1.51 \mathrm{mmol}, 1.0$ equiv) and Boc-Gly-DAla-OH (21) (483 mg, $1.962 \mathrm{mmol}, 1.0$ equiv) in DMF (5 mL) was added HATU (861 mg, $2.26 \mathrm{mmol}, 1.5$ equiv) and DIPEA ( $0.5 \mathrm{~mL}, 3.02 \mathrm{mmol}, 1.0$ equiv) and the mixture was stirred for $12 \mathrm{~h}$ at $25{ }^{\circ} \mathrm{C}$. After this time, a saturated aqueous $\mathrm{NH}_{4} \mathrm{Cl}$ solution was added and the organic layer was separated. The aqueous phase was extracted with EtOAc, and the combined organic layers were washed with brine, dried over anhydrous $\mathrm{MgSO}_{4}$, filtered and the solvent evaporated under reduced pressure. The crude product was purified by flash column chromatography (silica gel, 15\% EtOAc in hexanes $\rightarrow 35 \%$ EtOAc in hexanes) to obtain dipeptide 67 (554 mg, 81\%) as a yellow foam: $\mathrm{R}_{f}=0.64$ (silica gel, $100 \%$ EtOAc); $[\alpha]^{25} \mathrm{D}=-$ $3.96\left(c\right.$ 0.15, $\left.\mathrm{CH}_{2} \mathrm{Cl}_{2}\right) ;{ }^{1} \mathrm{H} \mathrm{NMR}\left(400 \mathrm{MHz}, \mathrm{CDCl}_{3}\right) \delta(\mathrm{ppm}) 8.30(\mathrm{~d}, J=13.1 \mathrm{~Hz}, 1 \mathrm{H}), 7.60$ (bs, $1 \mathrm{H}), 7.46-7.30(\mathrm{~m}, 7 \mathrm{H}), 6.78(\mathrm{~d}, J=2.7 \mathrm{~Hz}, 1 \mathrm{H}), 6.76-6.69(\mathrm{~m}, 1 \mathrm{H}), 5.56(\mathrm{~d}, J=$ $17.3 \mathrm{~Hz}, 1 \mathrm{H}), 5.31(\mathrm{~d}, J=11.6 \mathrm{~Hz}, 1 \mathrm{H}), 5.18(\mathrm{bs}, 1 \mathrm{H}), 5.04(\mathrm{~s}, 2 \mathrm{H}), 4.68(\mathrm{p}, J=7.1 \mathrm{~Hz}, 1$ $\mathrm{H}), 3.88-3.79(\mathrm{~m}, 2 \mathrm{H}), 1.47(\mathrm{~d}, J=6.3 \mathrm{~Hz}, 3 \mathrm{H}), 1.43(\mathrm{~s}, 9 \mathrm{H}) ;{ }^{13} \mathrm{C}$ NMR $(100 \mathrm{MHz}$, $\left.\mathrm{CDCl}_{3}\right) \delta(\mathrm{ppm}) 170.2,170.1,158.8,156.2,136.8,135.1,131.4,128.5,127.9,127.6,123.2$, 120.4, 116.0, 112.8, 109.1, 80.7, 70.1, 49.6, 44.4, 28.3, 17.5; HRMS (H-ESI) $m / z:[\mathrm{M}+\mathrm{H}]^{+}$ calcd for $\mathrm{C}_{25} \mathrm{H}_{32} \mathrm{~N}_{3} \mathrm{O}_{5} 454.2342$; found 454.2340. 
Diolefin 69. Dipeptide 67 (70 mg, $0.15 \mathrm{mmol}, 1.0$ equiv) in $\mathrm{CH}_{2} \mathrm{Cl}_{2}(10 \mathrm{~mL})$ was treated with TFA $(2.2 \mathrm{~mL})$ in exactly the same manner as previously described for synthesis of $\mathbf{2 4}$. A solution of the resulting ammonium salt and hexenoic acid $\mathbf{6 8}(18 \mu \mathrm{L}, 0.15 \mathrm{mmol}, 1.0$ equiv), in $\mathrm{CH}_{2} \mathrm{Cl}_{2}(15 \mathrm{~mL})$ was treated with BOP $(66 \mathrm{mg}, 0.15 \mathrm{mmol}, 1.0$ equiv) and DIPEA (77 $\mu \mathrm{L}$, $0.45 \mathrm{mmol}, 3.0$ equiv) and the resulting solution was stirred at $25^{\circ} \mathrm{C}$ for $12 \mathrm{~h}$. After this time, a saturated aqueous $\mathrm{NH}_{4} \mathrm{Cl}$ solution was added and the organic layer was separated. The aqueous phase was extracted with EtOAc, and the combined organic layers were washed with brine, dried over anhydrous $\mathrm{MgSO}_{4}$, filtered and the solvent evaporated under reduced pressure. The resulting residue was purified by flash column chromatography (silica gel, 30\% EtOAc in hexanes) to obtain diolefin $69(51 \mathrm{mg}, 74 \%$ over two steps $)$ as a white solid: $\mathrm{R}_{f}=$ 0.45 (silica gel, $100 \%$ EtOAc); $[\alpha]^{25} \mathrm{D}=-9.02\left(c 0.11, \mathrm{CH}_{2} \mathrm{Cl}_{2}\right) ; \mathrm{mp}=82-83{ }^{\circ} \mathrm{C} ;{ }^{1} \mathrm{H}$ NMR $\left(400 \mathrm{MHz}, \mathrm{CDCl}_{3}\right) \delta(\mathrm{ppm}) 8.24(\mathrm{bs}, 1 \mathrm{H}), 7.58(\mathrm{bs}, 1 \mathrm{H}), 7.44-7.30(\mathrm{~m}, 6 \mathrm{H}), 7.06(\mathrm{~s}, 1 \mathrm{H})$, $6.80-6.75(\mathrm{~m}, 1 \mathrm{H}), 6.72(\mathrm{dd}, J=16.1,9.7 \mathrm{~Hz}, 1 \mathrm{H}), 6.34(\mathrm{~s}, 1 \mathrm{H}), 5.74$ (ddt, $J=17.0,10.0$, $6.8 \mathrm{~Hz}, 1 \mathrm{H}), 5.56(\mathrm{~d}, J=17.3 \mathrm{~Hz}, 1 \mathrm{H}), 5.29(\mathrm{~d}, J=11.0 \mathrm{~Hz}, 1 \mathrm{H}), 5.05-5.00(\mathrm{~m}, 3 \mathrm{H}), 5.00$ $-4.93(\mathrm{~m}, 1 \mathrm{H}), 4.71-4.61(\mathrm{~m}, 1 \mathrm{H}), 4.06-3.93(\mathrm{~m}, 2 \mathrm{H}), 2.23(\mathrm{td}, J=7.8,1.7 \mathrm{~Hz}, 2 \mathrm{H})$, $2.10-2.02(\mathrm{~m}, 2 \mathrm{H}), 1.77-1.68(\mathrm{~m}, 2 \mathrm{H}), 1.48(\mathrm{~d}, J=7.0 \mathrm{~Hz}, 3 \mathrm{H}) ;{ }^{13} \mathrm{C}$ NMR $(100 \mathrm{MHz}$, $\left.\mathrm{CDCl}_{3}\right) \delta(\mathrm{ppm}) 173.8,170.1,169.4,158.9,137.7,136.7,135.1,131.4,128.6,128.0,127.6$, 127.6, 123.0, 116.1, 115.5, 112.7, 109.0, 70.1, 49.8, 43.3, 35.4, 33.1, 24.5, 17.6; HRMS (HESI) $m / z:[\mathrm{M}+\mathrm{H}]^{+}$calcd for $\mathrm{C}_{26} \mathrm{H}_{32} \mathrm{~N}_{3} \mathrm{O}_{4} 450.2393$; found 450.2391.

Macrocycle 70. Diolefin 69 (19 mg, $0.08 \mathrm{mmol}, 1.0$ equiv), Hoveyda-Grubbs $2^{\text {nd }}$ generation catalyst (3 mg, $0.004 \mathrm{mmol}, 0.10$ equiv) and $p$-benzoquinone $(1.0 \mathrm{mg}, 0.004 \mathrm{mmol}, 0.10$ equiv) were dissolved in degassed $\mathrm{CH}_{2} \mathrm{Cl}_{2}(2 \mathrm{~mL}, 0.02 \mathrm{M})$ and the reaction mixture was 
heated at $40{ }^{\circ} \mathrm{C}$ for $12 \mathrm{~h}$. After this time, the solvent was removed under reduced pressure and the resulting crude product was purified by flash column chromatography (silica gel, $\mathrm{CH}_{2} \mathrm{Cl}_{2}$ $\rightarrow 3 \% \mathrm{MeOH}$ in $\left.\mathrm{CH}_{2} \mathrm{Cl}_{2}\right)$ to obtain macrocycle $\mathbf{7 0}(6.1 \mathrm{mg}, 43 \%)$ as a white solid: $\mathrm{R}_{f}=0.76$ (silica gel, $10 \% \mathrm{MeOH}$ in $\left.\mathrm{CH}_{2} \mathrm{Cl}_{2}\right) ;[\alpha]^{25} \mathrm{D}=-5.32(c 0.09, \mathrm{MeOH}) ; \mathrm{mp}=196-197 ;{ }^{1} \mathrm{H} \mathrm{NMR}$ $\left(400 \mathrm{MHz}, \mathrm{DMSO}-d_{6}\right) \delta(\mathrm{ppm}) 8.54(\mathrm{bs}, 1 \mathrm{H}), 8.40(\mathrm{t}, J=5.9 \mathrm{~Hz}, 1 \mathrm{H}), 7.46-7.35(\mathrm{~m}, 5 \mathrm{H})$, $7.32(\mathrm{~d}, J=7.0 \mathrm{~Hz}, 1 \mathrm{H}), 7.29(\mathrm{~d}, J=2.5 \mathrm{~Hz}, 1 \mathrm{H}), 7.06(\mathrm{~d}, J=8.5 \mathrm{~Hz}, 1 \mathrm{H}), 6.77(\mathrm{dd}, J=8.4$, $2.6 \mathrm{~Hz}, 1 \mathrm{H}), 5.42(\mathrm{dt}, J=15.8,5.2 \mathrm{~Hz}, 1 \mathrm{H}), 5.04(\mathrm{~s}, 2 \mathrm{H}), 4.40-4.31(\mathrm{~m}, 1 \mathrm{H}), 3.85(\mathrm{dd}, J=$ 14.8, 6.3 Hz, $1 \mathrm{H}), 3.45(\mathrm{dd}, J=14.8,5.6 \mathrm{~Hz}, 1 \mathrm{H}), 3.20(\mathrm{dd}, J=15.5,5.1 \mathrm{~Hz}, 1 \mathrm{H}), 3.03$ (dd, $J=15.5,5.2 \mathrm{~Hz}, 1 \mathrm{H}), 2.34-2.04(\mathrm{~m}, 4 \mathrm{H}), 1.30(\mathrm{~d}, J=7.1 \mathrm{~Hz}, 3 \mathrm{H}) ;{ }^{13} \mathrm{C} \mathrm{NMR}(100 \mathrm{MHz}$, DMSO- $\left.d_{6}\right) \delta(\mathrm{ppm}) 173.1,171.4,171.1,157.4,137.6,137.3,131.6,130.7,128.9,128.2$, 128.1, 128.09, 128.0, 125.8, 111.8, 69.7, 49.7, 43.4, 34.7, 33.7, 27.9, 16.8; HRMS (H-ESI) $m / z:[\mathrm{M}+\mathrm{H}]^{+}$calcd for $\mathrm{C}_{24} \mathrm{H}_{28} \mathrm{~N}_{3} \mathrm{O}_{4} 422.2079$; found 422.2073 .

Diolefin 59. Dipeptide 67 (420 mg, $0.93 \mathrm{mmol}, 1.0$ equiv) in $\mathrm{CH}_{2} \mathrm{Cl}_{2}$ (10 mL) was treated with TFA $(4.6 \mathrm{~mL})$ in exactly the same manner as previously described for synthesis of $\mathbf{2 4}$. A solution of the corresponding ammonium salt and acid $\mathbf{6 2}$ (174 mg, $1.20 \mathrm{mmol}, 1.3$ equiv), in $\mathrm{CH}_{2} \mathrm{Cl}_{2}(15 \mathrm{~mL})$ was treated with HATU (528 mg, $1.39 \mathrm{mmol}, 1.0$ equiv) and DIPEA (0.5 $\mathrm{mL}, 2.78 \mathrm{mmol}, 3.0$ equiv) and the resulting solution was stirred at $25^{\circ} \mathrm{C}$ for $12 \mathrm{~h}$. After this time, a saturated aqueous $\mathrm{NH}_{4} \mathrm{Cl}$ solution was added and the organic layer was separated. The aqueous phase was extracted with EtOAc, and the combined organic layers were washed with brine, dried over anhydrous $\mathrm{MgSO}_{4}$, filtered and the solvent evaporated under reduced pressure. The resulting residue was purified by flash column chromatography (silica gel, 50\% EtOAc in hexanes $\rightarrow 100 \%$ EtOAc) to obtain diolefin $\mathbf{5 9}$ (67 mg, 86\% over two steps) as a white solid: $\mathrm{R}_{f}=0.46$ (silica gel, $10 \% \mathrm{MeOH}$ in $\left.\mathrm{CH}_{2} \mathrm{Cl}_{2}\right) ;[\alpha]^{25} \mathrm{D}=-3.98(c 0.07, \mathrm{MeOH})$; 
$\mathrm{mp}=88-89{ }^{\circ} \mathrm{C} ;{ }^{1} \mathrm{H}$ NMR $(400 \mathrm{MHz}, \mathrm{MeOD}) \delta(\mathrm{ppm}) 7.53(\mathrm{~d}, J=8.7 \mathrm{~Hz}, 1 \mathrm{H}), 7.44-7.27$ (m, $6 \mathrm{H}), 7.04(\mathrm{~d}, J=2.6 \mathrm{~Hz}, 1 \mathrm{H}), 6.89(\mathrm{dd}, J=8.7,2.6 \mathrm{~Hz}, 1 \mathrm{H}), 6.80(\mathrm{dd}, J=17.5,11.1 \mathrm{~Hz}$, $1 \mathrm{H}), 5.98-5.82(\mathrm{~m}, 1 \mathrm{H}), 5.62(\mathrm{dd}, J=17.4,1.2 \mathrm{~Hz}, 1 \mathrm{H}), 5.20(\mathrm{dd}, J=11.0,1.3 \mathrm{~Hz}, 1 \mathrm{H})$, $5.11(\mathrm{dd}, J=18.9,1.7 \mathrm{~Hz}, 1 \mathrm{H}), 5.07(\mathrm{~s}, 2 \mathrm{H}), 5.07-5.03(\mathrm{~m}, 1 \mathrm{H}), 4.55-4.47(\mathrm{~m}, 1 \mathrm{H}), 4.02$ $(\mathrm{d}, J=16.9 \mathrm{~Hz}, 1 \mathrm{H}), 3.79(\mathrm{~d}, J=16.9 \mathrm{~Hz}, 1 \mathrm{H}), 3.71(\mathrm{td}, J=7.3,4.0 \mathrm{~Hz}, 1 \mathrm{H}), 2.48-2.38$ $(\mathrm{m}, 2 \mathrm{H}), 2.27-2.18(\mathrm{~m}, 1 \mathrm{H}), 1.46(\mathrm{~d}, J=7.2 \mathrm{~Hz}, 3 \mathrm{H}), 1.11(\mathrm{~d}, J=6.9 \mathrm{~Hz}, 3 \mathrm{H}) ;{ }^{13} \mathrm{C} \mathrm{NMR}$ (100 MHz, MeOD) $\delta(\mathrm{ppm}) 177.3,172.7,170.5,163.5,158.7,137.1,134.9,134.2,131.6$, $128.1,127.6,127.2,126.4,116.5,113.5,112.9,112.1,73.1,69.7,42.3,38.6,35.6,30.3,16.5$, 12.9; HRMS (H-ESI) m/z: [M + H] $]^{+}$calcd for $\mathrm{C}_{27} \mathrm{H}_{34} \mathrm{~N}_{3} \mathrm{O}_{5}$ 480.2499; found 480.2501.

Diolefin 71. To a solution of diolefin 59 (35 mg, $0.07 \mathrm{mmol}, 1.0$ equiv) in $\mathrm{CH}_{2} \mathrm{Cl}_{2}$ (5 mL) was added 2,6-lutidine ( $20 \mu \mathrm{L}, 0.15 \mathrm{mmol}, 2.0$ equiv) at $0{ }^{\circ} \mathrm{C}$ and the mixture was stirred $10 \mathrm{~min}$ at this temperature. After this time TBSOTf $(0.03 \mathrm{~mL}, 0.15 \mathrm{mmol}, 2.0$ equiv $)$ was added at $0{ }^{\circ} \mathrm{C}$ and the mixture was stirred for $12 \mathrm{~h}$ at $25^{\circ} \mathrm{C}$. Then, the reaction was quenched by addition of $\mathrm{H}_{2} \mathrm{O}$. After decantation of the organic layer, the aqueous phase was extracted with EtOAc, and the combined organic layers were washed with brine, dried over anhydrous $\mathrm{MgSO}_{4}$, filtered and the solvent evaporated under reduced pressure. The crude product was purified by flash column chromatography (silica gel, 20\% EtOAc in hexanes $\rightarrow 100 \%$ EtOAc) to obtain diolefin 71 (31 mg, 72\%) as a white solid: $\mathrm{R}_{f}=0.80$ (silica gel, $100 \%$ EtOAc); $[\alpha]^{25}{ }_{\mathrm{D}}=-6.98$ $\left(c\right.$ 0.06, MeOH); mp $=96-97{ }^{\circ} \mathrm{C} ;{ }^{1} \mathrm{H}$ NMR $(400 \mathrm{MHz}, \mathrm{MeOD}) \delta(\mathrm{ppm}) 7.52(\mathrm{~d}, J=8.7 \mathrm{~Hz}, 1$ H), $7.44-7.40(\mathrm{~m}, 2 \mathrm{H}), 7.39-7.33(\mathrm{~m}, 2 \mathrm{H}), 7.33-7.27(\mathrm{~m}, 1 \mathrm{H}), 7.06(\mathrm{~d}, J=2.6 \mathrm{~Hz}, 1 \mathrm{H})$, $6.89(\mathrm{dd}, J=8.7,2.7 \mathrm{~Hz}, 1 \mathrm{H}), 6.79$ (dd, $J=17.5,11.1 \mathrm{~Hz}, 1 \mathrm{H}), 5.89$ (dddd, $J=16.5,10.4$, 8.2, $6.0 \mathrm{~Hz}, 1 \mathrm{H}), 5.62(\mathrm{dd}, J=17.5,1.3 \mathrm{~Hz}, 1 \mathrm{H}), 5.19(\mathrm{dd}, J=11.0,1.3 \mathrm{~Hz}, 1 \mathrm{H}), 5.11-$ $5.07(\mathrm{~m}, 1 \mathrm{H}), 5.07(\mathrm{~s}, 2 \mathrm{H}), 5.06-5.03(\mathrm{~m}, 1 \mathrm{H}), 4.56-4.49(\mathrm{~m}, 1 \mathrm{H}), 4.07(\mathrm{~d}, J=16.5 \mathrm{~Hz}, 1$ 
H), $3.98-3.89(\mathrm{~m}, 1 \mathrm{H}), 3.70(\mathrm{~d}, J=16.6 \mathrm{~Hz}, 1 \mathrm{H}), 2.58-2.46(\mathrm{~m}, 1 \mathrm{H}), 2.40-2.22(\mathrm{~m}, 2$ H), $1.47(\mathrm{~d}, J=7.1 \mathrm{~Hz}, 3 \mathrm{H}), 1.08(\mathrm{~d}, J=7.0 \mathrm{~Hz}, 3 \mathrm{H}), 0.87(\mathrm{~s}, 9 \mathrm{H}), 0.08$ (s, $3 \mathrm{H}), 0.03$ (s, 3 $\mathrm{H}) ;{ }^{13} \mathrm{C}$ NMR (100 MHz, MeOD) $\delta$ (ppm) 176.9, 172.6, 169.9, 158.7, 137.1, 134.9, 133.7, $131.6,128.1,127.5,127.2,126.4,125.9,116.6,113.4,112.9,112.0,73.3,69.7,49.4,45.9$, 42.0, 38.1, 24.9, 17.5, 16.8, 12.7, -5.6, -6.1; HRMS (H-ESI) $m / z:[\mathrm{M}+\mathrm{H}]^{+}$calcd for $\mathrm{C}_{33} \mathrm{H}_{48} \mathrm{~N}_{3} \mathrm{O}_{5} \mathrm{Si}$ 594.3363; found 594.3367.

Macrocycle 72. Diolefin 71 (20 mg, $0.03 \mathrm{mmol}, 1.0$ equiv), Hoveyda-Grubbs $2^{\text {nd }}$ generation catalyst (2 mg, $0.003 \mathrm{mmol}, 0.10$ equiv) and $p$-benzoquinone $(1.0 \mathrm{mg}, 0.003 \mathrm{mmol}, 0.10$ equiv) were dissolved in degassed $\mathrm{CH}_{2} \mathrm{Cl}_{2}(2 \mathrm{~mL}, 0.02 \mathrm{M})$ and the reaction mixture was heated at $40{ }^{\circ} \mathrm{C}$ for $12 \mathrm{~h}$. After this time, the solvent was removed under reduced pressure and the resulting crude product was purified by flash column chromatography (silica gel, 20\% EtOAc in hexanes $\rightarrow 60 \%$ EtOAc in hexanes) to obtain macrocycle $72(9.0 \mathrm{mg}, 47 \%)$ as a white solid: $\mathrm{R}_{f}=0.51$ (silica gel, 70\% EtOAc in hexanes); $[\alpha]^{25} \mathrm{D}=-9.21(c 0.08, \mathrm{MeOH})$; $\mathrm{mp}=205-206{ }^{\circ} \mathrm{C} ;{ }^{1} \mathrm{H}$ NMR $(400 \mathrm{MHz}, \mathrm{MeOD}) \delta(\mathrm{ppm}) 7.44-7.27(\mathrm{~m}, 6 \mathrm{H}), 7.08(\mathrm{~d}, J=2.6$ $\mathrm{Hz}, 1 \mathrm{H}), 6.85(\mathrm{dd}, J=8.7,2.8 \mathrm{~Hz}, 1 \mathrm{H}), 6.45(\mathrm{~d}, J=15.8 \mathrm{~Hz}, 1 \mathrm{H}), 5.98(\mathrm{ddd}, J=15.4,7.5$, $3.1 \mathrm{~Hz}, 1 \mathrm{H}), 5.07(\mathrm{~s}, 2 \mathrm{H}), 4.25(\mathrm{q}, J=7.2 \mathrm{~Hz}, 1 \mathrm{H}), 4.13(\mathrm{td}, J=6.6,3.7 \mathrm{~Hz}, 1 \mathrm{H}), 3.96(\mathrm{~d}, J$ $=14.6 \mathrm{~Hz}, 1 \mathrm{H}), 3.74(\mathrm{~d}, J=14.6 \mathrm{~Hz}, 1 \mathrm{H}), 2.59-2.49(\mathrm{~m}, 3 \mathrm{H}), 1.54(\mathrm{~d}, J=7.2 \mathrm{~Hz}, 3 \mathrm{H})$, $1.15(\mathrm{~d}, J=7.2 \mathrm{~Hz}, 3 \mathrm{H}), 0.95(\mathrm{~s}, 9 \mathrm{H}), 0.15$ (overlap two singlets, $6 \mathrm{H}) ;{ }^{13} \mathrm{C}$ NMR $(100 \mathrm{MHz}$, $\mathrm{MeOD}) \delta(\mathrm{ppm}) 176.8,171.6,171.3,158.2,137.2,134.5,128.6,128.1,127.5,127.2,126.3$, $126.2,125.4,113.3,112.3,73.4,69.7,50.9,46.3,43.3,38.9,24.9,17.5,14.6,12.0,-5.7,-6.1$; HRMS (H-ESI) $m / z:[\mathrm{M}+\mathrm{Na}]^{+}$calcd for $\mathrm{C}_{31} \mathrm{H}_{43} \mathrm{~N}_{3} \mathrm{O}_{5} \mathrm{SiNa}$ 588.2870; found 588.2868. 
Diolefin 73. To a solution of diolefin $59\left(53 \mathrm{mg}, 0.11 \mathrm{mmol}, 1.0\right.$ equiv) in $\mathrm{CH}_{2} \mathrm{Cl}_{2}(10 \mathrm{~mL})$ was added 2,6-lutidine ( $30 \mu \mathrm{L}, 0.28 \mathrm{mmol}, 2.5$ equiv) at $0{ }^{\circ} \mathrm{C}$ and the mixture was stirred 10 min at this temperature. After this time TESOTf $(0.06 \mathrm{~mL}, 0.30 \mathrm{mmol}, 2.5$ equiv) was added at $0{ }^{\circ} \mathrm{C}$ and the mixture was stirred for $12 \mathrm{~h}$ at $25^{\circ} \mathrm{C}$. Then, the reaction was quenched by addition of $\mathrm{H}_{2} \mathrm{O}$. After decantation of the organic layer, the aqueous phase was extracted with EtOAc, and the combined organic layers were washed with brine, dried over anhydrous $\mathrm{MgSO}_{4}$, filtered and the solvent evaporated under reduced pressure. The crude product was purified by flash column chromatography (silica gel, 15\% EtOAc in hexanes $\rightarrow 60 \%$ EtOAc) to obtain diolefin 73 (45 mg, 68\%) as a white solid: $\mathrm{R}_{f}=0.80$ (silica gel, $100 \%$ EtOAc); $[\alpha]^{25}$ $\mathrm{D}=-9.41(c 0.08, \mathrm{MeOH}) ; \mathrm{mp}=92-93{ }^{\circ} \mathrm{C} ;{ }^{1} \mathrm{H} \mathrm{NMR}\left(400 \mathrm{MHz}, \mathrm{CDCl}_{3}\right) \delta(\mathrm{ppm}) 7.53(\mathrm{~d}, J=$ $8.7 \mathrm{~Hz}, 1 \mathrm{H}), 7.45-7.40(\mathrm{~m}, 2 \mathrm{H}), 7.39-7.33(\mathrm{~m}, 2 \mathrm{H}), 7.31(\mathrm{dt}, J=5.3,2.1 \mathrm{~Hz}, 1 \mathrm{H}), 7.06$ $(\mathrm{d}, J=2.6 \mathrm{~Hz}, 1 \mathrm{H}), 6.89(\mathrm{dd}, J=8.5,2.4 \mathrm{~Hz}, 1 \mathrm{H}), 6.80(\mathrm{dd}, J=17.5,11.0 \mathrm{~Hz}, 1 \mathrm{H}), 5.89$ (dddd, $J=16.5,10.3,8.1,6.1 \mathrm{~Hz}, 1 \mathrm{H}), 5.62(\mathrm{dd}, J=17.5,1.3 \mathrm{~Hz}, 1 \mathrm{H}), 5.20(\mathrm{dd}, J=11.0$, $1.3 \mathrm{~Hz}, 1 \mathrm{H}), 5.13-5.03(\mathrm{~m}, 4 \mathrm{H}), 4.53(\mathrm{q}, J=7.0 \mathrm{~Hz}, 1 \mathrm{H}), 4.06(\mathrm{~d}, J=16.6 \mathrm{~Hz}, 1 \mathrm{H}), 3.97-$ $3.91(\mathrm{~m}, 1 \mathrm{H}), 3.74(\mathrm{~d}, J=16.5 \mathrm{~Hz}, 1 \mathrm{H}), 2.54-2.44(\mathrm{~m}, 1 \mathrm{H}), 2.40-2.22(\mathrm{~m}, 2 \mathrm{H}), 1.47(\mathrm{~d}, J$ $=7.1 \mathrm{~Hz}, 3 \mathrm{H}), 1.09(\mathrm{~d}, J=7.0 \mathrm{~Hz}, 3 \mathrm{H}), 0.95(\mathrm{t}, J=7.9 \mathrm{~Hz}, 9 \mathrm{H}), 0.61(\mathrm{q}, J=7.6 \mathrm{~Hz}, 6 \mathrm{H})$; ${ }^{13} \mathrm{C}$ NMR $\left(100 \mathrm{MHz}, \mathrm{CDCl}_{3}\right) \delta(\mathrm{ppm}) 176.9,172.7,169.9,158.7,137.1,134.9,133.9,131.6$, $128.1,127.5,127.2,126.4,125.9,116.6,113.4,112.9,112.0,73.4,69.7,49.4,46.1,41.9$, 38.5, 16.7, 12.9, 5.9, 4.5; HRMS (H-ESI) $m / z:[\mathrm{M}+\mathrm{H}]^{+}$calcd for $\mathrm{C}_{33} \mathrm{H}_{48} \mathrm{~N}_{3} \mathrm{O}_{5} \mathrm{Si}$ 594.3363; found 594.3359.

Macrocycle 74. Diolefin 73 (22 mg, $0.04 \mathrm{mmol}, 1.0$ equiv), Hoveyda-Grubbs $2^{\text {nd }}$ generation catalyst ( $2 \mathrm{mg}, 0.004 \mathrm{mmol}, 0.10$ equiv) and $p$-benzoquinone $(1.0 \mathrm{mg}, 0.004 \mathrm{mmol}, 0.10$ equiv) were dissolved in degassed $\mathrm{CH}_{2} \mathrm{Cl}_{2}(2 \mathrm{~mL}, 0.02 \mathrm{M})$ and the reaction mixture was 
heated at $40{ }^{\circ} \mathrm{C}$ for $12 \mathrm{~h}$. After this time, the solvent was removed under reduced pressure and the resulting crude product was purified by flash column chromatography (silica gel, $30 \%$ EtOAc in hexanes $\rightarrow 60 \%$ EtOAc in hexanes) to obtain macrocycle 74 (11 $\mathrm{mg}, 53 \%)$ as a white solid: $\mathrm{R}_{f}=0.28$ (silica gel, 70\% EtOAc in hexanes); $[\alpha]^{25} \mathrm{D}=-11.08(c 0.09, \mathrm{MeOH})$; $\mathrm{mp}=198-199{ }^{\circ} \mathrm{C} ;{ }^{1} \mathrm{H}$ NMR $(400 \mathrm{MHz}, \mathrm{MeOD}) \delta(\mathrm{ppm}) 7.44-7.40(\mathrm{~m}, 2 \mathrm{H}), 7.39-7.33(\mathrm{~m}$, $3 \mathrm{H}), 7.33-7.27(\mathrm{~m}, 2 \mathrm{H}), 7.08(\mathrm{~d}, J=2.6 \mathrm{~Hz}, 1 \mathrm{H}), 6.85(\mathrm{dd}, J=8.6,2.5 \mathrm{~Hz}, 1 \mathrm{H}), 6.46(\mathrm{~d}, J$ $=15.7 \mathrm{~Hz}, 1 \mathrm{H}), 6.02-5.93(\mathrm{~m}, 1 \mathrm{H}), 5.07(\mathrm{~s}, 2 \mathrm{H}), 4.24(\mathrm{q}, J=7.1 \mathrm{~Hz}, 1 \mathrm{H}), 4.14(\mathrm{dd}, J=$ 10.2, $6.6 \mathrm{~Hz}, 1 \mathrm{H}), 3.95$ (d, $J=14.6 \mathrm{~Hz}, 1 \mathrm{H}), 3.74(\mathrm{~d}, J=14.4 \mathrm{~Hz}, 1 \mathrm{H}), 2.65-2.46(\mathrm{~m}, 3 \mathrm{H})$, $1.54(\mathrm{~d}, J=7.2 \mathrm{~Hz}, 3 \mathrm{H}), 1.17(\mathrm{~d}, J=7.2 \mathrm{~Hz}, 3 \mathrm{H}), 1.02(\mathrm{t}, J=7.9 \mathrm{~Hz}, 9 \mathrm{H}), 0.70(\mathrm{q}, J=7.5$ $\mathrm{Hz}, 6 \mathrm{H}) ;{ }^{13} \mathrm{C}$ NMR (100 MHz, MeOD) $\delta(\mathrm{ppm}) 176.8,171.6,171.3,158.1,137.2,134.5$, $128.7,128.1,127.5,127.2,126.3,126.0,125.4,113.3,112.3,73.2,69.9,50.9,46.3,39.1$, 29.3, 14.6, 12.2, 5.9, 4.4; HRMS (H-ESI) $m / z:[\mathrm{M}+\mathrm{H}]^{+}$calcd for $\mathrm{C}_{31} \mathrm{H}_{44} \mathrm{~N}_{3} \mathrm{O}_{5} \mathrm{Si}$ 566.3050; found 566.3067 .

Macrocycle 58. To a solution of macrocycle 74 (5.0 mg, $0.01 \mathrm{mmol}, 1.0$ equiv) in THF (3 $\mathrm{mL})$ was added at $0{ }^{\circ} \mathrm{C}$ TBAF $(18 \mu \mathrm{L}, 1.0 \mathrm{M}$ in THF, $0.018 \mathrm{mmol}, 2.0$ equiv). After $95 \mathrm{~min}$ the solvent was removed under reduced pressure and the crude mixture was purified by preparative TLC (silica gel $60 \mathrm{~F}_{254}, 1 \mathrm{~mm}, 100 \%$ EtOAc) to obtain macrocycle $\mathbf{5 8}(3.4 \mathrm{mg}$, 85\%) as a white solid: $\mathrm{R}_{f}=0.27$ (silica gel, $100 \%$ EtOAc); $[\alpha]^{25} \mathrm{D}=-7.72(c 0.04, \mathrm{MeOH})$; $\mathrm{mp}=201-202{ }^{\circ} \mathrm{C} ;{ }^{1} \mathrm{H}$ NMR $(400 \mathrm{MHz}, \mathrm{MeOD}) \delta(\mathrm{ppm}) 7.44-7.40(\mathrm{~m}, 2 \mathrm{H}), 7.38-7.32(\mathrm{~m}$, $3 \mathrm{H}), 7.32-7.27(\mathrm{~m}, 1 \mathrm{H}), 7.19(\mathrm{~d}, J=2.6 \mathrm{~Hz}, 1 \mathrm{H}), 6.85(\mathrm{dd}, J=8.6,2.6 \mathrm{~Hz}, 1 \mathrm{H}), 6.41(\mathrm{~d}, J$ $=15.4 \mathrm{~Hz}, 1 \mathrm{H}), 6.00(\mathrm{dt}, J=15.4,7.4 \mathrm{~Hz}, 1 \mathrm{H}), 5.08(\mathrm{~s}, 2 \mathrm{H}), 4.55(\mathrm{~s}, 1 \mathrm{H}), 4.45(\mathrm{q}, J=7.1$ $\mathrm{Hz}, 1 \mathrm{H}), 4.06(\mathrm{~d}, J=14.9 \mathrm{~Hz}, 1 \mathrm{H}), 3.87(\mathrm{td}, J=6.8,2.9 \mathrm{~Hz}, 1 \mathrm{H}), 3.72(\mathrm{~d}, J=14.9 \mathrm{~Hz}, 1 \mathrm{H})$, $2.56-2.50(\mathrm{~m}, 3 \mathrm{H}), 1.47(\mathrm{~d}, J=7.2 \mathrm{~Hz}, 3 \mathrm{H}), 1.25(\mathrm{~d}, J=7.2 \mathrm{~Hz}, 3 \mathrm{H}) ;{ }^{13} \mathrm{C} \mathrm{NMR}(100$ 
$\mathrm{MHz}, \mathrm{MeOD}) \delta(\mathrm{ppm}) 176.7,171.6,170.7,158.3,137.1,134.5,128.9,128.1,127.6,127.5$, 127.2, 126.7, 125.1, 113.0, 111.3, 72.3, 69.8, 50.1, 44.9, 42.9, 39.2, 15.3, 13.5; HRMS (HESI) $m / z:[\mathrm{M}+\mathrm{H}]^{+}$calcd for $\mathrm{C}_{25} \mathrm{H}_{30} \mathrm{~N}_{3} \mathrm{O}_{5} 452.2186$; found 452.2170 .

Homoallylic Alcohol 77. A solution of aldehyde 40 (395 mg, $1.54 \mathrm{mmol}, 1.0$ equiv) in $\mathrm{CH}_{2} \mathrm{Cl}_{2}(15 \mathrm{~mL})$ was cooled to $0{ }^{\circ} \mathrm{C}$ and $\mathrm{SnCl}_{4}(0.8 \mathrm{~mL}, 0.77 \mathrm{mmol}, 0.5$ equiv, $1.0 \mathrm{M}$ in $\mathrm{CH}_{2} \mathrm{Cl}_{2}$ ) was added slowly over $10 \mathrm{~min}$ at this temperature and then stirred for $10 \mathrm{~min}$ at 25 ${ }^{\circ} \mathrm{C}$. Allyl trimethylsilane $(0.35 \mathrm{~mL}, 2.30 \mathrm{mmol}, 1.5$ equiv $)$ was added quickly and the reaction was stirred for $15 \mathrm{~min}$, poured into $\mathrm{Et}_{2} \mathrm{O}$ and after decantation the organic phase was washed with brine, dried over anhydrous $\mathrm{MgSO}_{4}$, filtered and the solvent evaporated under reduced pressure. The crude product was purified by flash column chromatography (silica gel, 5\% EtOAc in Hexanes) to obtain the homoallylic alcohol 77 (340 mg, 74\%) as a yellow solid: $\mathrm{R}_{f}$ $=0.67$ (silica gel, $40 \%$ EtOAc in hexanes); $\mathrm{mp}=74-75^{\circ} \mathrm{C} ;{ }^{1} \mathrm{H} \mathrm{NMR}\left(400 \mathrm{MHz}, \mathrm{CDCl}_{3}\right) \delta$ (ppm) $7.71(\mathrm{~d}, J=8.8 \mathrm{~Hz}, 1 \mathrm{H}), 7.52(\mathrm{~d}, J=2.7 \mathrm{~Hz}, 1 \mathrm{H}), 7.46-7.34(\mathrm{~m}, 5 \mathrm{H}), 7.26-7.23$ (m, $1 \mathrm{H}), 5.88$ (dddd, $J=16.9,10.5,7.8,6.4 \mathrm{~Hz}, 1 \mathrm{H}), 5.26-5.19(\mathrm{~m}, 2 \mathrm{H}), 5.17$ (t, $J=1.1$ $\mathrm{Hz}, 1 \mathrm{H}), 5.12(\mathrm{~s}, 2 \mathrm{H}), 2.67$ (dddt, $J=14.0,6.4,3.8,1.3 \mathrm{~Hz}, 1 \mathrm{H}), 2.47-2.34(\mathrm{~m}, 2 \mathrm{H}) ;{ }^{13} \mathrm{C}$ NMR $\left(100 \mathrm{MHz}, \mathrm{CDCl}_{3}\right) \delta(\mathrm{ppm})$ 158.0, 148.4, 135.8, 134.2, 131.5, 129.3, 128.8, 128.4, 127.6, 120.8, 118.9, 109.9, 70.7, 68.2, 42.8; HRMS (H-ESI) $m / z:[\mathrm{M}+\mathrm{H}]^{+}$calcd for $\mathrm{C}_{17} \mathrm{H}_{18} \mathrm{NO}_{4} 300.1236$; found 300.1238 .

Benzyloxymethyl Acetal 78. To a solution of the homoallylic alcohol 77 (226 mg, 0.76 mmol, 1.0 equiv) in $\mathrm{CH}_{2} \mathrm{Cl}_{2}(10 \mathrm{~mL})$ was added DIPEA (0.52 mL, $3.02 \mathrm{mmol}, 4.0$ equiv) and $\mathrm{BOMCl}\left(0.56 \mathrm{~mL}, 3.02 \mathrm{mmol}, 4.0\right.$ equiv) at $0{ }^{\circ} \mathrm{C}$ and the mixture was stirred at $25^{\circ} \mathrm{C}$ for $15 \mathrm{~h}$. After this time, the reaction was quenched by addition of saturated aqueous $\mathrm{Na}_{2} \mathrm{CO}_{3}$ solution 
and the crude mixture was stirred for $30 \mathrm{~min}$. Then, the aqueous phase was extracted with $\mathrm{CH}_{2} \mathrm{Cl}_{2}$ and the organic phase washed with brine, dried over anhydrous $\mathrm{MgSO}_{4}$, filtered and the solvent evaporated under reduced pressure. The resulting residue was purified by flash column chromatography (silica gel, $3 \%$ EtOAc in hexanes) to obtain benzyloxymethyl acetal $78(280 \mathrm{mg}, 88 \%)$ as a pale yellow oil: $\mathrm{R}_{f}=0.50$ (silica gel, $20 \%$ EtOAc in hexanes); ${ }^{1} \mathrm{H}$ NMR (400 MHz, $\left.\mathrm{CDCl}_{3}\right) \delta(\mathrm{ppm}) 7.67(\mathrm{~d}, J=8.7 \mathrm{~Hz}, 1 \mathrm{H}), 7.53(\mathrm{~d}, J=2.6 \mathrm{~Hz}, 1 \mathrm{H}), 7.46-$ $7.22(\mathrm{~m}, 11 \mathrm{H}), 5.94(\mathrm{ddt}, J=17.1,10.1,7.0 \mathrm{~Hz}, 1 \mathrm{H}), 5.35(\mathrm{dd}, J=8.0,4.2 \mathrm{~Hz}, 1 \mathrm{H}), 5.15$ $(\mathrm{dd}, J=17.0,1.7 \mathrm{~Hz}, 2 \mathrm{H}), 5.11(\mathrm{~s}, 2 \mathrm{H}), 4.91(\mathrm{~d}, J=9.0 \mathrm{~Hz}, 1 \mathrm{H}), 4.71(\mathrm{dd}, J=21.3,5.5 \mathrm{~Hz}$, $2 \mathrm{H}), 4.66(\mathrm{~s}, 1 \mathrm{H}), 4.59(\mathrm{~d}, J=6.9 \mathrm{~Hz}, 1 \mathrm{H}), 4.47(\mathrm{~d}, J=11.8 \mathrm{~Hz}, 1 \mathrm{H}), 2.67-2.59(\mathrm{~m}, 1 \mathrm{H})$, $2.57-2.48(\mathrm{~m}, 1 \mathrm{H}) ;{ }^{13} \mathrm{C} \mathrm{NMR}\left(100 \mathrm{MHz}, \mathrm{CDCl}_{3}\right) \delta(\mathrm{ppm}) 158.1,148.9,137.6,135.8,134.3$, $130.3,129.7,128.8,128.4,128.4,127.8,127.7,127.6,120.8,117.8,109.7,93.1,73.3,70.7$ 69.8, 42.0; HRMS (H-ESI) $m / z:[\mathrm{M}+\mathrm{H}]^{+}$calcd for $\mathrm{C}_{25} \mathrm{H}_{26} \mathrm{NO}_{5} 420.1811$; found 420.1815 .

Aniline 79. To a solution of benzyloxymethyl acetal 78 (280 mg, $0.67 \mathrm{mmol}, 1.0$ equiv) in EtOH (6 mL) was added a solution of $\mathrm{NH}_{4} \mathrm{Cl}(179 \mathrm{mg}, 3.34 \mathrm{mmol}, 5.0$ equiv) in water $(4 \mathrm{~mL})$ followed by $\mathrm{Zn}$ dust (655 mg, $10.01 \mathrm{mmol}, 15.0$ equiv) in seven portions of 100 $\mathrm{mg}$ each over $30 \mathrm{~min}$ at $25{ }^{\circ} \mathrm{C}$. The mixture was stirred at this temperature for $15 \mathrm{~h}$ and then the reaction mixture was diluted with $\mathrm{CH}_{2} \mathrm{Cl}_{2}$ and water, filtered and rinsed with $\mathrm{CH}_{2} \mathrm{Cl}_{2}$. The filtrate was diluted with water and extracted with $\mathrm{CH}_{2} \mathrm{Cl}_{2}$, and the organic phase washed with brine, dried over anhydrous $\mathrm{MgSO}_{4}$, filtered and the solvent evaporated under reduced pressure. The resulting residue was purified by flash column chromatography (silica gel, 10\% EtOAc in hexanes) to obtain aniline $79(217 \mathrm{mg}, 87 \%)$ as a yellow oil: $\mathrm{R}_{f}=0.60$ (silica gel, 30\% EtOAc in hexanes); ${ }^{1} \mathrm{H}$ NMR (400 MHz, $\left.\mathrm{CDCl}_{3}\right) \delta(\mathrm{ppm}) 7.41-7.30(\mathrm{~m}, 10 \mathrm{H}), 6.94(\mathrm{~d}$, $J=8.4 \mathrm{~Hz}, 1 \mathrm{H}), 6.34(\mathrm{dd}, J=8.3,2.5 \mathrm{~Hz}, 1 \mathrm{H}), 6.28(\mathrm{~d}, J=2.5 \mathrm{~Hz}, 1 \mathrm{H}), 5.81(\mathrm{ddt}, J=17.2$, 
10.1, 7.0 Hz, $1 \mathrm{H}), 5.12$ (ddd, $J=17.1,3.4,1.4 \mathrm{~Hz}, 1 \mathrm{H}), 5.05(\mathrm{ddt}, J=10.2,2.1,1.0 \mathrm{~Hz}, 1$ H), $5.01(\mathrm{~s}, 2 \mathrm{H}), 4.90(\mathrm{~d}, J=9.1 \mathrm{~Hz}, 1 \mathrm{H}), 4.73-4.71(\mathrm{~m}, 2 \mathrm{H}), 4.67-4.63(\mathrm{~m}, 1 \mathrm{H}), 4.52(\mathrm{~d}$, $J=11.7 \mathrm{~Hz}, 1 \mathrm{H}), 4.20(\mathrm{bs}, 2 \mathrm{H}), 2.83-2.74(\mathrm{~m}, 1 \mathrm{H}), 2.62-2.53(\mathrm{~m}, 1 \mathrm{H}) ;{ }^{13} \mathrm{C} \mathrm{NMR}(100$ $\left.\mathrm{MHz}, \mathrm{CDCl}_{3}\right) \delta(\mathrm{ppm}) 159.5,146.5,137.8,137.2,135.3,130.6,128.6,128.4,128.0,127.9$, 127.7, 127.5, 117.1, 116.9, 104.1, 102.9, 91.9, 77.9, 69.8, 69.7, 38.7; HRMS (H-ESI) m/z: [M $+\mathrm{H}]^{+}$calcd for $\mathrm{C}_{25} \mathrm{H}_{28} \mathrm{NO}_{3} 390.2069$; found 390.2071.

Peptide 80. To a solution of aniline 79 (217 mg, 0.56 mmol, 1.0 equiv) and Fmoc-D-Ala-OH (34) (225 mg, $0.72 \mathrm{mmol}, 1.3$ equiv) in $\mathrm{CH}_{2} \mathrm{Cl}_{2}(10 \mathrm{~mL}$ ) was added PyBOP (435 mg, 0.84 mmol, 1.5 equiv) and DIPEA (0.2 mL, $1.11 \mathrm{mmol}, 2.0$ equiv) at $0{ }^{\circ} \mathrm{C}$ and the mixture was stirred for $15 \mathrm{~h}$ at $25^{\circ} \mathrm{C}$. After this time, a saturated aqueous $\mathrm{NH}_{4} \mathrm{Cl}$ solution was added and the organic layer was separated. The aqueous phase was extracted with EtOAc, and the combined organic layers were washed with brine, dried over anhydrous $\mathrm{MgSO}_{4}$, filtered and the solvent evaporated under reduced pressure. The crude product was purified by flash column chromatography (silica gel, 30\% EtOAc in hexanes) to obtain peptide 80 (247 mg, $65 \%, 1: 1$ mixture of diastereoisomers) as a white foam. Data assigned for the mixture of diastereoisomers: $\mathrm{R}_{f}=0.20$ (silica gel, 30\% EtOAc in hexanes); ${ }^{1} \mathrm{H}$ NMR (400 MHz, $\mathrm{CDCl}_{3}$ ) $\delta(\mathrm{ppm}) 9.32(\mathrm{~d}, J=11.0 \mathrm{~Hz}, 1 \mathrm{H}), 8.03(\mathrm{~d}, J=8.7 \mathrm{~Hz}, 1 \mathrm{H}), 7.77(\mathrm{~d}, J=7.4 \mathrm{~Hz}, 2 \mathrm{H}), 7.61$ $(\mathrm{d}, J=6.0 \mathrm{~Hz}, 2 \mathrm{H}), 7.47-7.27(\mathrm{~m}, 13 \mathrm{H}), 7.21(\mathrm{dd}, J=7.2,5.5 \mathrm{~Hz}, 2 \mathrm{H}), 7.02(\mathrm{~d}, J=8.4 \mathrm{~Hz}$, $1 \mathrm{H}), 6.69(\mathrm{dd}, J=8.4,2.5 \mathrm{~Hz}, 1 \mathrm{H}), 5.72(\mathrm{td}, J=16.8,6.9 \mathrm{~Hz}, 1 \mathrm{H}), 5.40(\mathrm{~d}, J=6.5 \mathrm{~Hz}, 1 \mathrm{H})$, $5.13-5.01(\mathrm{~m}, 4 \mathrm{H}), 4.77-4.64(\mathrm{~m}, 3 \mathrm{H}), 4.64-4.56(\mathrm{~m}, J=11.4,8.2 \mathrm{~Hz}, 1 \mathrm{H}), 4.54-4.45$ $(\mathrm{m}, 1 \mathrm{H}), 4.43-4.32(\mathrm{~m}, 2 \mathrm{H}), 4.23(\mathrm{dd}, J=14.3,7.2 \mathrm{~Hz}, 1 \mathrm{H}), 2.73-2.61(\mathrm{~m}, 1 \mathrm{H}), 2.53-$ $2.40(\mathrm{~m}, 1 \mathrm{H}), 1.51-1.42(\mathrm{~m}, 3 \mathrm{H}) ;{ }^{13} \mathrm{C} \mathrm{NMR}\left(100 \mathrm{MHz}, \mathrm{CDCl}_{3}\right) \delta(\mathrm{ppm}) 170.3,159.1$ $159.0,155.8,143.8,141.3,137.3,137.2,136.8,134.2,134.1,129.9,129.9,128.5,128.5$, 
$128.4,127.9,127.9,127.9,127.9,127.9,127.8,127.6,127.1,125.2,125.0,120.0,117.9$, $117.8,111.1,108.3,108.1,92.4,78.6,70.1,70.0,67.1,51.6,47.1,39.9,39.9,18.9,18.9$; HRMS (H-ESI) $m / z:[\mathrm{M}+\mathrm{H}]^{+}$calcd for $\mathrm{C}_{43} \mathrm{H}_{43} \mathrm{~N}_{2} \mathrm{O}_{6} 683.3121$; found 683.3115 .

Dipeptide 81. To a solution of peptide 80 (176 mg, $0.26 \mathrm{mmol}, 1.0$ equiv) in $\mathrm{CH}_{2} \mathrm{Cl}_{2}(5 \mathrm{~mL})$ was added piperidine $(0.13 \mathrm{~mL}, 1.29 \mathrm{mmol}, 5.0$ equiv $)$ and the reaction mixture was stirred at $25^{\circ} \mathrm{C}$ for $5 \mathrm{~h}$. After this time, the organic solvent was removed under redued pressure and the resulting crude product was purified by fash column chromatography (silica gel, 30\% EtOAc in hexanes $\rightarrow 60 \%$ EtOAc in hexanes) to obtain the corresponding amine (110 mg, 93\%, 1:1 mixture of diastereoisomers) as a white solid. Data assigned for the mixture of diastereoisomers: $\mathrm{R}_{f}=0.18$ (silica gel, 80\% EtOAc in hexanes); $\mathrm{mp}=82-83{ }^{\circ} \mathrm{C} ;{ }^{1} \mathrm{H}$ NMR $\left(400 \mathrm{MHz}, \mathrm{CDCl}_{3}\right) \delta(\mathrm{ppm}) 8.15-8.01(\mathrm{~m}, 1 \mathrm{H}), 7.48-7.21(\mathrm{~m}, 12 \mathrm{H}), 7.12-6.99(\mathrm{~m}, 1 \mathrm{H})$, $6.74-6.62(\mathrm{~m}, 1 \mathrm{H}), 5.84-5.67(\mathrm{~m}, 1 \mathrm{H}), 5.13-4.99(\mathrm{~m}, 5 \mathrm{H}), 4.83-4.64(\mathrm{~m}, 4 \mathrm{H}), 4.58-$ $4.45(\mathrm{~m}, 1 \mathrm{H}), 3.76(\mathrm{bs}, 1 \mathrm{H}), 2.71(\mathrm{dt}, J=14.8,8.0 \mathrm{~Hz}, 1 \mathrm{H}), 2.50(\mathrm{dt}, J=13.6,6.6 \mathrm{~Hz}, 1 \mathrm{H})$, $1.53-1.25(\mathrm{~m}, 3 \mathrm{H}) ;{ }^{13} \mathrm{C} \mathrm{NMR}\left(100 \mathrm{MHz}, \mathrm{CDCl}_{3}\right) \delta(\mathrm{ppm}) 172.3,171.9,159.1,159.0,137.6$ $137.5,137.5,137.5,137.4,137.3,137.3,137.3,136.9,136.9,134.5,134.4,128.5,128.5$, $128.5,128.5,128.1,128.0,127.9,127.9,127.6,121.4,121.2,117.8,117.7,110.8,110.6$, 108.5, 108.2, 92.3, 92.3, 70.1, 70.0, 69.9, 61.4, 61.2, 51.4, 51.3, 40.1, 39.9, 16.4, 15.8. To a solution of the amine obtained above (105 mg, $0.23 \mathrm{mmol}, 1.0$ equiv) and Fmoc-Gly-OH (35) ( $88 \mathrm{mg}, 0.30 \mathrm{mmol}, 1.3$ equiv) in $\mathrm{CH}_{2} \mathrm{Cl}_{2}(5 \mathrm{~mL})$ was added HATU (130 mg, $0.34 \mathrm{mmol}, 1.5$ equiv) and DIPEA ( $0.1 \mathrm{~mL}, 0.46 \mathrm{mmol}, 2.0$ equiv) at $0{ }^{\circ} \mathrm{C}$ and the mixture was stirred for $15 \mathrm{~h}$ at $25^{\circ} \mathrm{C}$. After this time, a saturated aqueous $\mathrm{NH}_{4} \mathrm{Cl}$ solution was added and the organic layer was separated. The aqueous phase was extracted with EtOAc, and the combined organic layers were washed with brine, dried over anhydrous $\mathrm{MgSO}_{4}$, filtered and the solvent 
evaporated under reduced pressure. The crude product was purified by flash column chromatography (silica gel, 15\% EtOAc in hexanes $\rightarrow 40 \%$ EtOAc in hexanes) to obtain peptide 81 (123 mg, 73\%, 1:1 mixture of diastereoisomers) as a white foam. Data assigned for the mixture of diastereoisomers: $\mathrm{R}_{f}=0.27$ (silica gel, 50\% EtOAc in hexanes); ${ }^{1} \mathrm{H}$ NMR (400 $\left.\mathrm{MHz}, \mathrm{CDCl}_{3}\right) \delta(\mathrm{ppm}) 7.99-7.96(\mathrm{~m}, 1 \mathrm{H}), 7.75(\mathrm{dd}, J=7.5,3.4 \mathrm{~Hz}, 2 \mathrm{H}), 7.59(\mathrm{~d}, J=7.3$ $\mathrm{Hz}, 2 \mathrm{H}), 7.45-7.23(\mathrm{~m}, 16 \mathrm{H}), 7.03(\mathrm{t}, J=8.9 \mathrm{~Hz}, 1 \mathrm{H}), 6.71-6.66(\mathrm{~m}, 1 \mathrm{H}), 5.72(\mathrm{ttd}, J=$ 13.7, 7.0, 3.3 Hz, 1 H), 5.53 (bs, $1 \mathrm{H}), 5.13-5.06$ (m, $2 \mathrm{H}), 5.04$ (s, $2 \mathrm{H}), 4.77-4.55$ (m, 6 H), $4.44(\mathrm{~d}, J=6.8 \mathrm{~Hz}, 2 \mathrm{H}), 4.22(\mathrm{t}, J=6.9 \mathrm{~Hz}, 1 \mathrm{H}), 3.97-3.78(\mathrm{~m}, 2 \mathrm{H}), 2.64(\mathrm{dt}, J=16.3$, $7.0 \mathrm{~Hz}, 1 \mathrm{H}), 2.44$ (ddd, $J=20.6,13.8,6.5 \mathrm{~Hz}, 1 \mathrm{H}), 1.49-1.44(\mathrm{~m}, 3 \mathrm{H}) ;{ }^{13} \mathrm{C}$ NMR $(100$ $\left.\mathrm{MHz}, \mathrm{CDCl}_{3}\right) \delta(\mathrm{ppm}) 174.6,170.1,170.0,165.6,159.1,159.1,156.8,156.7,143.7,143.7$, $141.3,141.3,137.2,136.8,134.2,134.2,130.0,129.9,128.6,128.1,128.1,128.0,127.8$, $127.7,127.6,127.1,127.0,125.1,125.0,121.3,121.2,120.0,119.9,117.9,117.9,111.2$, $111.2,108.5,108.3,92.6,92.5,78.3,77.8,70.3,70.2,70.1,65.4,49.9,47.1,44.5,38.7,18.4$, 18.3; HRMS (H-ESI) m/z: $[\mathrm{M}+\mathrm{H}]^{+}$calcd for $\mathrm{C}_{45} \mathrm{H}_{46} \mathrm{~N}_{3} \mathrm{O}_{7} 740.3336$; found 740.3327 .

Diolefin 83. To a solution of peptide 81 (63 mg, $0.09 \mathrm{mmol}, 1.0$ equiv) in $\mathrm{CH}_{2} \mathrm{Cl}_{2}$ (5 mL) was added piperidine $(0.04 \mathrm{~mL}, 0.43 \mathrm{mmol}, 5.0$ equiv) and the reaction mixture was stirred at 25 ${ }^{\circ} \mathrm{C} 5 \mathrm{~h}$. After this time, the organic solvent was removed under reduced pressure and the resulting crude amine was used in the next step without purification. To a solution of the crude amine ( $\sim 0.09 \mathrm{mmol})$ and acid $82\left(10 \mu \mathrm{L}, 0.11 \mathrm{mmol}, 1.3\right.$ equiv) in $\mathrm{CH}_{2} \mathrm{Cl}_{2}(5 \mathrm{~mL})$ was added HATU (49 mg, $0.13 \mathrm{mmol}, 1.5$ equiv) and DIPEA (30 $\mu \mathrm{L}, 0.17 \mathrm{mmol}, 2.0$ equiv) at 0 ${ }^{\circ} \mathrm{C}$ and the mixture was stirred for $12 \mathrm{~h}$ at $25^{\circ} \mathrm{C}$. After this time, a saturated aqueous $\mathrm{NH}_{4} \mathrm{Cl}$ solution was added and the organic layer was separated. The aqueous phase was extracted with EtOAc, and the combined organic layers were washed with brine, dried over anhydrous 
$\mathrm{MgSO}_{4}$, filtered and the solvent evaporated under reduced pressure. The crude product was purified by flash column chromatography (silica gel, 30\% EtOAc in hexanes $\rightarrow 100 \%$ EtOAc) to obtain diolefin 83 (32 mg, 64\% over 2 steps, 1:1 mixture of diastereoisomers) as a white solid. Data assigned for the mixture of diastereoisomers: $\mathrm{R}_{f}=0.62$ (silica gel, 100\% EtOAc); $\mathrm{mp}=95-96{ }^{\circ} \mathrm{C} ;{ }^{1} \mathrm{H} \mathrm{NMR}\left(400 \mathrm{MHz}, \mathrm{CDCl}_{3}\right) \delta(\mathrm{ppm}) 7.95(\mathrm{t}, J=2.6 \mathrm{~Hz}, 1 \mathrm{H}), 7.46-7.27(\mathrm{~m}$, $12 \mathrm{H}), 7.03(\mathrm{t}, J=8.6 \mathrm{~Hz}, 1 \mathrm{H}), 6.85(\mathrm{~s}, 1 \mathrm{H}), 6.69(\mathrm{dt}, J=8.4,2.8 \mathrm{~Hz}, 1 \mathrm{H}), 5.99-5.84(\mathrm{~m}, 1$ H), $5.80-5.65(\mathrm{~m}, 1 \mathrm{H}), 5.27-5.19(\mathrm{~m}, 2 \mathrm{H}), 5.16-5.06(\mathrm{~m}, 2 \mathrm{H}), 5.05(\mathrm{~s}, 2 \mathrm{H}), 4.76-4.63$ (m, $4 \mathrm{H}), 4.56-4.46(\mathrm{~m}, 2 \mathrm{H}), 4.03-3.95(\mathrm{~m}, 2 \mathrm{H}), 3.07-3.00(\mathrm{~m}, 2 \mathrm{H}), 2.65(\mathrm{ddd}, J=15.3$, 13.9, $7.7 \mathrm{~Hz}, 1 \mathrm{H}), 2.44(\mathrm{ddd}, J=20.9,13.1,6.4 \mathrm{~Hz}, 1 \mathrm{H}), 1.49-1.43(\mathrm{~m}, 3 \mathrm{H}) ;{ }^{13} \mathrm{C} \mathrm{NMR}$ $\left(100 \mathrm{MHz}, \mathrm{CDCl}_{3}\right) \delta(\mathrm{ppm}) 174.5,171.8,171.4,170.1,168.8,165.7,160.2,159.1,140.9$, $137.2,137.1,136.8,136.8,134.3,134.2,130.7,129.9,129.9,128.8,128.6,128.1,128.1$, 128.0, 127.7, 127.7, 127.6, 127.0, 120.2, 120.1, 117.9, 117.8, 111.2, 111.1, 108.6, 108.4, 92.7, $92.5,78.8,70.3,70.3,70.2,70.1,50.1,50.1,43.1,43.0,41.2,41.2,38.7,18.3,18.2$; HRMS (H-ESI) $m / z:[\mathrm{M}+\mathrm{H}]^{+}$calcd for $\mathrm{C}_{34} \mathrm{H}_{40} \mathrm{~N}_{3} \mathrm{O}_{6} 586.2917$; found 586.2905.

Macrocycle 85. To a stirred solution of macrocycle 27 (28 mg, $0.07 \mathrm{mmol}, 1.0$ equiv) in THF $(10 \mathrm{~mL})$ at $-78^{\circ} \mathrm{C}$ was added condensed liquid $\mathrm{NH}_{3}(\sim 8 \mathrm{~mL})$ via cannula. Then, small pieces of $\mathrm{Na}(130 \mathrm{mg}, 5.61 \mathrm{mmol}, 85$ equiv) were added to the mixture until the formation of a deep blue solution. The reaction was stirred at $-78^{\circ} \mathrm{C}$ for $2 \mathrm{~h}$ and after this time it was quenched by slowly addition of $\mathrm{MeOH}$ at the same temperature. The mixture was allowed to reach room temperature and concentrated under reduced pressure to a volume of $\sim 10 \mathrm{~mL}$. The reaction was neutralized with Dowex- $\mathrm{H}^{+}$, washed with $\mathrm{MeOH}$ and concentrated under reduced pressure. The crude product was purified by flash column chromatography (silica gel, $7 \%$ $\mathrm{MeOH}$ in $\mathrm{CH}_{2} \mathrm{Cl}_{2}$ ) to obtain macrocycle $\mathbf{8 5}(18 \mathrm{mg}, 85 \%)$ as a white solid: $\mathrm{R}_{f}=0.34$ (silica 
gel, $10 \% \mathrm{MeOH}$ in $\left.\mathrm{CH}_{2} \mathrm{Cl}_{2}\right) ;[\alpha]^{25} \mathrm{D}=-6.77(c 0.09, \mathrm{MeOH}) ; \mathrm{mp}=125-126{ }^{\circ} \mathrm{C} ;{ }^{1} \mathrm{H} \mathrm{NMR}$ (400 MHz, DMSO-d $) \delta(\mathrm{ppm}) 9.30$ (bs, $1 \mathrm{H}), 8.51$ (d, $J=7.2 \mathrm{~Hz}, 1 \mathrm{H}), 8.38$ (bs, $1 \mathrm{H}), 7.03$ $(\mathrm{d}, J=2.4 \mathrm{~Hz}, 1 \mathrm{H}), 6.91(\mathrm{~d}, J=8.2 \mathrm{~Hz}, 1 \mathrm{H}), 6.49(\mathrm{dd}, J=8.2,2.5 \mathrm{~Hz}, 1 \mathrm{H}), 5.40(\mathrm{dt}, J=$ 15.1, 5.0 Hz, $1 \mathrm{H}), 5.07$ (dt, $J=15.1,5.7 \mathrm{~Hz}, 1 \mathrm{H}), 4.32$ (p, $J=7.0 \mathrm{~Hz}, 1 \mathrm{H}), 4.11(\mathrm{bs}, 1 \mathrm{H})$, $3.84(\mathrm{dd}, J=14.8,6.4 \mathrm{~Hz}, 1 \mathrm{H}), 3.43(\mathrm{dd}, J=14.8,5.6 \mathrm{~Hz}, 1 \mathrm{H}), 3.16-3.09(\mathrm{~m}, 1 \mathrm{H}), 2.96$ $(\mathrm{dd}, J=16.4,5.2 \mathrm{~Hz}, 1 \mathrm{H}), 2.28-2.08(\mathrm{~m}, 4 \mathrm{H}), 1.29(\mathrm{~d}, J=7.1 \mathrm{~Hz}, 3 \mathrm{H}) ;{ }^{13} \mathrm{C} \mathrm{NMR}(100$ MHz, DMSO- $\left.d_{6}\right) \delta 173.1,171.2,170.9,156.3,136.9,131.4,131.0,127.8,123.7,112.7$, 112.4, 49.7, 49.1, 43.4, 33.8, 27.9, 16.9; HRMS (H-ESI) m/z: $[\mathrm{M}+\mathrm{H}]^{+}$calcd for $\mathrm{C}_{17} \mathrm{H}_{22} \mathrm{~N}_{3} \mathrm{O}_{4}$ 332.1610; found 332.1618.

Cell growth assay. The 3-(4,5-dimethylthiazol-2-yl)-2,5-diphenyltetrazolium bromide or MTT dye reduction assay in 96-well microplates was used. ${ }^{32}$ This assay is dependent on the reduction of MTT by mitochondrial dehydrogenases of a viable cell to a blue formazan product, which can be measured spectrophotometrically. $2,5 \times 10^{3}$ BAEC, $3 \times 10^{3}$ HL-60 and KU812F and $2 \times 10^{3}$ HepG2, HT-1080, HT-29, MDA-MB-231, U2OS, U937 and U87MG cells in a total volume of $100 \mu \mathrm{L}$ of their respective growth medium were incubated with serial dilutions $1: 1$ of the tested compounds. After 3 days of incubation $\left(37^{\circ} \mathrm{C}\right.$ and $5 \% \mathrm{CO}_{2}$ in a humid atmosphere), $10 \mu \mathrm{L}$ of MTT (5 mg/mL in phosphate-buffered saline) were added to each well, and the plate was incubated for a further $4 \mathrm{~h}$ at $37{ }^{\circ} \mathrm{C}$. The resulting formazan was dissolved in $150 \mu \mathrm{L}$ of $0.04 \mathrm{~N} \mathrm{HCl} / 2$-propanol and read at $550 \mathrm{~nm}$. IC 50 values were calculated from semi-logarithmic dose-response plots as those concentrations of compound yielding $50 \%$ cell survival, taking the values obtained for the control to be $100 \%$. $\mathrm{IC}_{50}$ results are expressed as means \pm S.D. of at least three independent experiments.

\section{ASSOCIATED CONTENT}




\section{Supporting Information}

The Supporting Information is available free of charge on the ACS Publications website at DOI:

${ }^{1} \mathrm{H}$ and ${ }^{13} \mathrm{C}$ NMR spectra for all new compounds, dose-response plots of the biological studies and theoretical calculations data.

\section{AUTHOR INFORMATION}

\section{Corresponding Author}

*E-mail: frsarabia@uma.es

\section{Author Contributions}

The manuscript was written through contributions of all authors. / All authors have given approval to the final version of the manuscript. / II. C.-S. performed all the synthetic work and designed the experiments. A. S.-R. and J. M. L.-R. performed the theoretical calculations. P. C., B. M.-P., A. R. Q. and M. A. M. performed the biological evaluations. F. S. and I. C.-S. conceived and directed the study.

\section{Notes}

The authors declare no competing financial interest.

\section{ACKNOWLEDGMENT}

This work was financially supported by the Ministerio de Ciencias e Innovación (MICINN) (ref. CTQ2014-60223-R and CTQ2016-76311-R) and Junta de Andalucía and "Fondo Europeo de Desarrollo Regional-FEDER" (P12 CTS-1507). I. C.-S. thanks Ministerio de Educación, Cultura y Deporte for a predoctoral fellowship (FPU programme). The authors thank Dr. J. I. Trujillo from Pfizer (Groton, CT) for assistance in the preparation of this 
manuscript. The authors thank the Unidad de Espectroscopía de Masas and the NMR facility of the University of Málaga for exact mass and NMR spectroscopic assistance.

\section{REFERENCES}

1. Festa, C.; De Marino, S.; Sepe, V.; D’Auria, M. V.; Bifulco, G.; Débitus, C.; Bucci, M.; Vellecco, V.; Zampella, A. Org. Lett. 2011, 13, 1532-1535.

2. (a) Wegerski, C. J.; Hammond, J.; Tenney, K.; Matainaho, T.; Crews, P. J. Nat. Prod. 2007, 70, 89-94. (b) Festa, C.; De Marino, S.; Sepe, V.; Monti, M. C.; Luciano, P.; D’Auria, M. V.; Débitus, C.; Bucci, M.; Vellecco, V.; Zampella, A. Tetrahedron 2009, 65, 10424-10429 and references therein.

3. (a) Kavitha, N.; Kumar, V. P.; Chandrasekhar, S. Tetrahedron Lett. 2013, 54, 2128-2130.

(b) Kavitha, N.; Chandrasekhar, S. Org. Biomol. Chem. 2015, 13, 6242-6248.

4. (a) Kashinath, K.; Vasudevan, N.; Reddy, D. S. Org. Lett. 2012, 14, 6222-6225. (b)

Kashinath, K.; Dhara, S.; Reddy, D. S. Org. Lett. 2015, 17, 2090-2093.

5. Vasudevan, N.; Kashinath, K.; Reddy, D. S. Org. Lett. 2014, 16, 6148-6151.

6. Reddy, D. S.; Kormirishetty, K.; Natrajan, V. WO Patent 2014083578 A1, Nov 27, 2013; Chem. Abstr. 2014, 161, 70679.

7. Kashinath, K.; Jachak, G. R.; Athawale, P. R.; Marelli, U. K.; Gonnade, R. G.; Reddy, D. S. Org. Lett. 2016, 18, 3178-3181.

8. (a) Sarabia, F.; Chammaa, S.; Sánchez-Ruiz, A.; Martín-Ortiz, L.; López-Herrera, F. J. Curr. Med. Chem. 2004, 11, 1309-1332. (b) Sarabia, F.; Chammaa, S. J. Org. Chem. 2005, 70, 7846-7857. (c) Sarabia, F.; Chammaa, S.; García-Castro, M. J. Org. Chem. 2005, 70, 7858-7865. (d) Sarabia, F.; Chammaa, S.; García-Ruiz, C. J. Org. Chem. 2011, 
76, 2132-2144. (e) Goh, S.; Hohmeier, A.; Stone, T. C.; Offord, V.; Sarabia, F.; GarcíaRuiz, C.; Good, L. Appl. Environ. Microbiol. 2015, 81, 5650-5659.

9. Nicolaou, K. C.; Bulger, P. G.; Sarlah, D. Angew. Chem. Int. Ed. 2005, 44, 4490-4527.

10. Cheng-Sánchez, I.; García-Ruiz, C.; Sarabia, F. Tetrahedron Lett. 2016, 57, 3392-3395.

11. Jin-Gim, H.; Li, H.; Lee, E.; Ryu, J.-H.; Jeon, R. Bioorg. Med. Chem. Lett. 2013, 23, 513-517.

12. Asif, K.; Himaja, M.; Ramana, M. V.; Sikarwar, M. S. Asian J. Chem. 2012, 24, 2739-2743.

13. Hong, S. H.; Sanders, D. P.; Lee, C. W.; Grubbs, R. H. J. Am. Chem. Soc. 2005, 127, 17160-17161.

14. For representative examples of the influence of the structural pattern in the stereochemistry of the ring-closing metathesis, see: (a) Nicolaou, K. C.; He, Y.; Vourloumis, D.; Vallberg, H.; Roschangar, F.; Sarabia, F.; Ninkovic, S.; Yang, Z.; Trujillo, J. I. J. Am. Chem. Soc. 1997, 119, 7960-7973. (b) Vassilikogiannakis, G.; Margaros, I.; Tofi, M. Org. Lett. 2004, 6, 205-208. (c) Nicolaou, K. C.; Montagnon, T.; Vassilikogiannakis, G.; Mathison, C. J. N. J. Am. Chem. Soc. 2005, 127, 8872-8888.

15. (a) Hoye, T. R.; Zhao, H. Org. Lett. 1999, 1, 1123-1125. (b) Maishal, T. K.; SinhaMahapatra, D. K.; Paranjape, K.; Sarkar, A. Tetrahedron Lett. 2002, 43, 2263-2267. (c) Imahori, T.; Ojima, H.; Tateyama, H.; Mihara, Y.; Takahata, H. Tetrahedron Lett. 2008, 49, 265-268. (d) Imahori, T.; Ojima, H.; Yoshimura, Y.; Takahata, H. Chem. Eur. J. 2008, 14, 10762-10771.

16. (a) Cheng-Sánchez, I.; García-Ruiz, C.; Guerrero-Vásquez, G. A.; Sarabia, F. J. Org. Chem. 2017, 82, 4744-4757. (b) Paquette, L. A.; Efremov, I. J. Am. Chem. Soc. 2001, 
123, 4492-4501. (c) Gurjar, M. K.; Yakambram, P. Tetrahedron Lett. 2001, 42, $3633-3636$.

17. Carrión, M. D.; Chayah, M.; Entrena, A.; López, A.; Gallo, M. A.; Acuña-Castroviejo, D.; Camacho, M. E. Bioorg. Med. Chem. 2013, 21, 4132-4142.

18. For a comprehensive revision of different methods of Boc cleavage see: (a) Dandepally, S. R.; Williams, A. L. Tetrahedron Lett. 2009, 50, 1071-1074. (b) Kumar, G. P.; Rambabu, D.; Rao, M. V. B.; Pal, M. J. Chem. 2013, 2013, 916960; Chem. Abstr. 2013, 160,723475 .

19. Hengartner, U.; Batcho, A. D.; Blount, J. F.; Leimgruber, W.; Larscheid, M. E.; Scott, J. W. J. Org. Chem. 1979, 44, 3748-3752.

20. (a) Martín-Ortiz, L.; Chammaa, S.; Pino-González, M. S.; Sánchez-Ruiz, A.; GarcíaCastro, M.; Assiego, C.; Sarabia, F. Tetrahedron Lett. 2004, 45, 9069-9072. (b) Miyashita, M.; Mizutani, T.; Tadano, G.; Iwata, Y.; Miyazawa, M.; Tanino, K. Angew. Chem. Int. Ed. 2005, 44, 5094-5097. (c) Yu, X.-Q.; Yoshimura, F.; Ito, F.; Sasaki, M.; Hirai, A.; Tanino, K.; Miyashita, M. Angew. Chem. Int. Ed. 2008, 47, 750-754.

21. Yang, D.; Wong, M.-K.; Yip, Y.-C. J. Org. Chem. 1995, 60, 3887-3889.

22. DFT calculations were carried out using Gaussian 09 at the B3LYP/6-31G' level of theory using the SMD solvation methodology, choosing acetonitrile as solvent.

23. Aoyama, A.; Endo-Umeda, K.; Kishida, K.; Ohgane, K.; Noguchi-Yachide, T.; Aoyama, H.; Ishikawa, M.; Miyachi, H.; Makishima, M.; Hashimoto, Y. J. Med. Chem. 2012, 55, $7360-7377$.

24. Wagner, H.; Harms, K.; Koert, U.; Meder, S.; Boheim, G. Angew. Chem. Int. Ed. 1996, $35,2643-2646$.

25. Engelhardt, F. C.; Schmitt, M. J.; Taylor, R. E. Org. Lett. 2001, 3, 2209-2212. 
26. Hoveyda, A. H.; Lombardi, P. J.; O’Brien, R. V.; Zhugralin, A. R. J. Am. Chem. Soc. 2009, 131, 8378-8379.

27. (a) Lin, Y. A.; Davis, B. G. Beilstein J. Org. Chem. 2010, 6, 1219-1228. (b) Fuwa, H.; Saito, A.; Sasaki, M. Angew. Chem. Int. Ed. 2010, 49, 3041-3044. (c) Schmidt, B.; Staude, L. J. Org. Chem. 2009, 74, 9237-9240. (d) Schmidt, B.; Nave, S. Chem. Commun. 2006, 2489-2491.

28. (a) Fürstner, A.; Thiel, O. R.; Lehmann, C. W. Organometallics 2002, 21, 331-335. (b) Choi, T.-L.; Chatterjee, A. K.; Grubbs, R. H. Angew. Chem. Int. Ed. 2001, 40, 1277-1279. (c) Chatterjee, A. K.; Choi, T.-L.; Sanders, D. P.; Grubbs, R. H. J. Am. Chem. Soc. 2003, 125, 11360-11370.

29. For representative examples see: (a) Lübbe, C.; Dumrath, A.; Neumann, H.; Beller, M.; Kadyrov, R. ChemCatChem 2014, 6, 105-108. (b) Nagarapu, L.; Gaikwad, H. K.; Bantu, R.; Manikonda, S. R.; Kumar, C. G.; Pombala, S. Tetrahedron Lett. 2012, 53, 1287-1291. (c) Pentzer, E. B.; Gadzikwa, T.; Nguyen, S. T. Org. Lett. 2008, 10, 5613-5615. (d) Vedrenne, E.; Dupont, H.; Oualef, S.; Elkaïm, L.; Grimaud, L. Synlett 2005, 670-672.

30. Cárdenas, C; Quesada, A. R.; Medina, M. A. Cell. Mol. Life Sci. 2006, 63, 3083-3089.

31. Minimum energy conformations were calculated using the PM3 method found in HyperChem 5.0 software. Optimization was performed using Polak-Ribiere algorithm until the RMS gradient reached a value below $0.001 \mathrm{kcal} /(\AA \mathrm{A} \cdot \mathrm{mol})$.

32. Mosmann, T. J. Immunol. Methods 1983, 65, 55-63. 
